\title{
Ciguatera poisonings: A global review of occurrences and trends
}

\author{
Chinain M. ${ }^{1,}{ }^{*}$, Gatti C. M., I ${ }^{1}$, Darius H. T. ${ }^{1}$, Quod J-P ${ }^{2}$, Tester P. A. ${ }^{3}$ \\ 1 Inst Louis Malarde, Lab Marine Biotoxins, UMR 241, EIO, BP 30, F-98713 Tahiti, French Polynesi, \\ France. \\ 2 ARVAM Pareto, Technopole La Reunion,14 Rue Henri Cornu, F-97490 St Clotilde, La Reunion, \\ France. \\ ${ }^{3}$ Ocean Tester LLC, 295 Dills Point Rd, Beaufort, NC 28516 ,USA. \\ * Corresponding author: M. Chinain, email address : mchinain@ilm.pf
}

\begin{abstract}
:
Ciguatera Poisoning $(\mathrm{CP})$ is the most prevalent, phycotoxin related seafood poisoning across the globe, affecting between 10,000 and 50,000 people annually. This illness results from the consumption of seafood contaminated with lipid soluble toxins known as ciguatoxins (CTXs) that are produced by benthic dinoflagellates in the genera Gambierdiscus and Fukuyoa. The present work reviews the global occurrence of CP events and outbreaks, based on both scientific and gray literature.
\end{abstract}

Ciguatera prevalence is significantly underestimated due to a lack of recognition of ciguatera symptoms, limited collection of epidemiological data on a global level, and reticence to report ciguatera in CPendemic regions. Analysis of the time-series data available for a limited number of countries indicates the highest incidence rates are consistently reported from two historical CP-endemic areas i.e., the Pacific and Caribbean regions, a situation due in part to the strong reliance of local communities on marine resources. Ciguatera-related fatalities are rare ( $<0.1 \%$ of reported cases). The vast majority of outbreaks involve carnivorous fish including snappers, groupers, wrasses, and barracudas. Since 2000, an expansion of the geographical range of $\mathrm{CP}$ has been observed in several areas like Macaronesia and east and southeast Asia. In some of these locales, random surveys confirmed the presence of CTXs in locally sourced fish, consistent with the concurrent report of novel CP incidents (e.g., Canary Islands, Madeira, Selvagens Islands, New South Wales). One characteristic of outbreaks occurring in Asia is that they often present as large disease clusters due to group consumption of a single contaminated fish. Similar observations are reported from the Indian Ocean in the form of shark poisoning outbreaks which often lead to singular types of CP characterized by a high fatality rate. Other atypical forms of CP linked to the consumption of marine invertebrates also have been documented recently. Owing to the significant health, socioeconomic and socio-cultural impacts of ciguatera, there is an urgent need for increased, standardized, coordinated efforts in ciguatera education, monitoring and research programs. Several regional and international initiatives have emerged recently, that may help improve patients? care, data collection at a global scale, and risk monitoring and management capabilities in countries most vulnerable to CP's toxic threat. 


\section{Highlights}

A geographical expansion of ciguatera poisoning incidents is observed since 2000. Atypical forms of CP involving sharks and marine invertebrates are reported. CP cases and outbreaks remain largely under-reported on a global level. - Gambierdiscus and Fukuyoa spp. global distribution is updated and summarized.

Keywords: Ciguatera poisoning, Outbreaks, Epidemiology, Atypical forms, Global occurrence, Gambierdiscus spp, Fukuyoa spp, ciguatoxins, Toxin analyses 


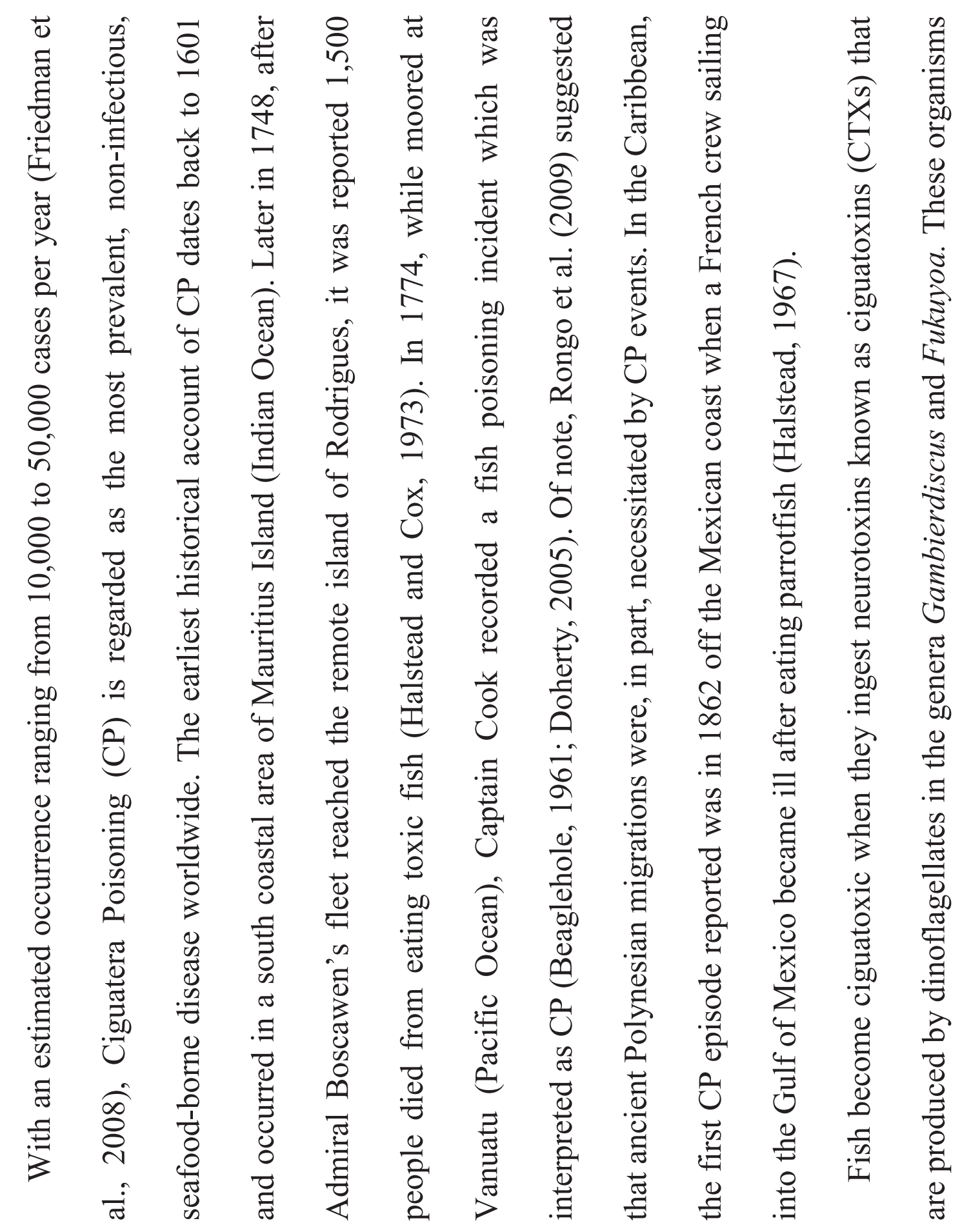


grow preferentially within mixed algal 'turf' that grows on degraded coral substrates, although these organisms also may be found in sand, coral, detritus and on other surfaces (Rains and Parsons, 2015; Yong et al., 2018). Fish get contaminated via their diet: CTXs enter the coral reef food web through grazing by herbivores and detritivores, and are further bio-magnified and bio-transformed as they move (or are transferred) in the food web (Anderson and Lobel, 1987). It is not possible to distinguish a tainted or toxic fish from an untainted one by appearance, texture, smell or taste. More than 400 species of fish are regarded as potential vectors of CTXs (Halstead, 1978; Food and Drug Administration, 2013; Mattei et al., 2014) (see also Supplementary Information S2). There is recent evidence that several species of marine invertebrates also may be involved in ciguatera transmission pathways (Rongo and van Woesik, 2011; Mak et al., 2013; Silva et al., 2015; Roué et al., 2016; Darius et al., 2018b; Darius et al., 2018a; Roué et al., 2018).

The true incidence of CP is difficult to ascertain due to significant under-reporting of the disease, failure to recognize its symptoms, and limited collection of epidemiological data on a global level (Friedman et al., 2008; Goater et al., 2011; Skinner et al., 2011; Friedman et al., 2017). Despite these continuing difficulties with diagnosis and reporting, ciguatera is presently recognized as a major health issue globally, especially among endemic communities. Ciguatera also has strong local and international socio-economic consequences. In affected countries, CP may lead to a significant drop in local fish consumption (Nellis and Barnard, 1986; Biaggi, 1990; Sadovy, 1997), or to a drastic modification of local populations' lifestyle, resulting in a progressive dietary shift in favor of imported and/or canned products (Rongo and van Woesik, 2011). Moreover, current risk management practices including bans on the sale of high-risk fish species, specimens over a certain size, or those from known toxic locations, may cause severe financial losses to both local and international fish trades (Sadovy, 1998; Chan, 2000; Clua et al., 2011; Sumner et al., 2011; Sydney Fish Market, 2015; Sanchez- 
Henao et al., 2019). Finally, CP also can represent a major source of concern to the tourism industry in endemic regions. In 2020, 55 countries and island territories were identified as "Ciguatera at-risk destinations" by the International Association for Medical Assistance to Travellers (IAMAT, 2017). This situation can lead to significant losses in the tourism industry as it may discourage local fish consumption in travelers, and cause a substantial slowdown in recreational fishing activities (Anderson et al., 2000; Sanseverino et al., 2016).

Until the 2000s, the distribution of ciguatera-causing organisms and ciguatoxic fish was thought to be limited to regions between latitudes $35^{\circ} \mathrm{N}$ and $35^{\circ} \mathrm{S}$ (i.e., the Pacific and Indian Oceans and Caribbean Sea). First reports of consumer illness and/or detection of ciguatoxic fish caught in previously non-endemic areas, can be found in the literature as early as 2004 from localized areas such as the Macaronesia (Canary Islands, Madeira, Azores, Cape Verde), the coast of Cameroon in West Africa, the eastern Mediterranean, or the western Gulf of Mexico (Pérez-Arellano et al., 2005; Bentur and Spanier, 2007; Villareal et al., 2007; Bienfang et al., 2008; Otero et al., 2010). In most of these instances, confirmation of CTXs in implicated toxic meals was consistent with the detection of Gambierdiscus species within the respective regions (Villareal et al., 2007; Aligizaki and Nikolaidis, 2008; Tester et al., 2013; Rodríguez et al., 2017, and references therein). A review of ciguatera poisoning occurrences at a global scale appears timely to determine if there has been a global intensification of CP events/outbreaks over the past decades.

The present review is based on data collated from both scientific and grey literature (reports, press releases, health and fishery authorities' websites, local media, personal communications). First, updated information on the global distribution of the causative organisms Gambierdiscus and Fukuyoa spp. is summarized. A second section briefly describes the clinical features of CP including singular forms of CP linked to the consumption of sharks and marine invertebrates. The third section examines the current gaps and 
weaknesses in CP data collection at a global scale, presents incidence rates in historically recognized endemic regions, then provides a summary of CP occurrences by region, including in newly affected areas of the Atlantic Ocean. A last section addresses the role played by various potential drivers in increased $\mathrm{CP}$ trends such as socio-cultural determinants, climate change, tourism and fish trade. A concluding section closes the review identifying areas for future research efforts in the frame of current international initiatives.

\section{Global distribution of the ciguatera-causing dinoflagellates Gambierdiscus and}

\section{Fukuyoa}

Gambierdiscus and Fukuyoa species are preferentially found in tropical and sub-tropical waters of the globe between $35^{\circ} \mathrm{N}$ and $35^{\circ} \mathrm{S}$ (Bienfang et al., 2008; Chinain et al., 2020) although recent studies now show that Gambierdiscus and/or Fukuyoa spp. are also well established in some temperate areas, including Korea (Jeong et al., 2012; Jang et al., 2018); Japan (Nishimura et al., 2016), the Kermadec Islands (New-Zealand) (Rhodes et al., 2017a; Rhodes et al., 2017c), southern Australia, the northern Gulf of Mexico (Tester et al., 2013), and the Mediterranean Sea (Aligizaki and Nikolaidis, 2008). This current range expansion of CP causing organisms may be due, in part, to global warming (see section 4.2) (Gingold et al., 2014; Rhodes et al., 2017a; Tester et al., 2020a). Figure 1A illustrates the current global distribution of Gambierdiscus and Fukuyoa genera. The complete list of references documenting species occurrence region by region can also be found in Supplementary Information S1.

Until 1995, Gambierdiscus was regarded as a monotypic taxon with all Gambierdiscus cells recorded as « G. toxicus » (Adachi and Fukuyo, 1979). The study by Chinain et al. (1999) was the first to combine morphological data with phylogenetic analyses in taxonomic determination of Gambierdiscus species. Using the same approach, Litaker et al. (2009) 
further provided a complete revision of the genus in 2009, making it possible to unambiguously identify Gambierdiscus species. Over the past decade, the extensive use and diversification of molecular methods for taxonomic assessments (e.g., Polymerase Chain Reaction, Restriction Fragment Length Polymorphism, Fluorescent In Situ Hybridization) have resulted in a significant increase in the number of new Gambierdiscus species being described. Overall, 18 species of Gambierdiscus are now recognized worldwide, of which 11 species have been found to produce CTX compounds as measured by LC-MS and/or functional assays (Litaker et al., 2017; Chinain et al., 2020; Tester et al., 2020a) for reviews and references therein).

Among the major locales presently regarded as $\mathrm{CP}$-endemic areas, the Pacific region is the area where the diversity and geographic distribution of Gambierdiscus species are best documented and this region continues to be the site of extensive sampling efforts. Since 2016, six of the eight newly described Gambierdiscus species originated from various Pacific locales, i.e. G. balechii (Fraga et al., 2016), G. lapillus (Kretzschmar et al., 2017), G. cheloniae (Smith et al., 2016), G. honu (Rhodes et al., 2017b), G. lewisii and G. holmesii (Kretzschmar et al., 2019). It is highly likely that additional species will be characterized in the coming years. Currently 18 Gambierdiscus/Fukuyoa spp. of the 21 species described are known in the Pacific Ocean basin, i.e., including the South China Sea. The only two species not yet reported from these areas are G. carolinianus and G. silvae. Moreover, several island groups in the South Pacific such as French Polynesia, the Cook Islands and the Republic of Kiribati are recognized as biodiversity "hotspots" of Gambierdiscus. For example, up to six Gambierdiscus species were found to co-exist within a single site of Rikitea Bay on Mangareva Island, a historical ciguatera hotspot in the Gambier archipelago (French Polynesia) (Chinain et al., 2016). Similarly, eight species are currently known in Australia 
from tropical Queensland to the more temperate waters of New South Wales (S1 and references therein).

The first Caribbean Gambierdiscus species, G. belizeanus, was described by Faust in 1995 (Faust, 1995) and six other Gambierdiscus and Fukuyoa species plus Gambierdiscus ribotype 2 have been added (S2). These species are widely distributed from the coast of Texas eastward to St. Maarten and from North Carolina and Florida in the US South Atlantic Bight south to Curacao (Fig. 1). There is high diversity of most of the species so it is not unusual to see five or six species co-occur in well sampled areas (Flower Garden Reef off Texas, Florida Keys, Cuba, Puerto Rico, Belize) (Tester et al., 2013; Díaz-Asencio et al., 2019b). Gambierdiscus excentricus and G. silvae, potentially the most toxic, are not encountered as frequently as the other species and their thermal tolerances may be a factor in their distributional patterns. Gambierdiscus excentricus, found at depths of 60 m (Litaker et al., 2019) on Pulley Ridge reef in the eastern Gulf of Mexico, ranges as far north as $29.21^{\circ} \mathrm{N}$, in the Canary Islands. There it has been associated with reports of CP after consumption of locally sourced fish since the early 2000s (Pérez-Arellano et al., 2005; Boada et al., 2010; Otero et al., 2010; Bravo et al., 2015; Núñez-Vázquez et al., 2019; Sanchez-Henao et al., 2019; Sanchez-Henao et al., 2020). Its southern range is the coast of Brazil $\left(22.74^{\circ} \mathrm{S}\right)$ (Nascimento et al., 2015), but this wide geographical range is somewhat misleading. It is not abundant in tropical waters as might be surmised by its lower optimum growth temperature (Tester et al., 2020a) and may occur only in cooler water at higher latitudes or at depths that are not yet well sampled in tropical or subtropical habitats (Kibler et al., 2015; Litaker et al., 2019) (S1 and references therein). Its only occurrence in the Pacific was recently documented by Rhodes et al. (2020), in the Cook Islands.

In the Indian Ocean region, the diversity of Gambierdiscus and Fukuyoa spp. has remained poorly documented until recently. Data collected as part of a biodiversity inventory and 
regional surveys conducted in La Réunion, Seychelles, Mauritius, Madagascar and Comoros confirmed that Gambierdiscus occurred in $80 \%$ of samples (Quod et al., 2000; Ten-Hage et al., 2000a; Ten-Hage et al., 2000b; Hansen, 2001). Gambierdiscus spp. was observed at depths of $\approx 60 \mathrm{~m}$ in La Pérouse seamount, an area known to harbor ciguatoxic fish located $150 \mathrm{~km}$ north of La Réunion, while South Africa is regarded as the southernmost place for tropical Gambierdiscus species, with reports of their presence near Durban (Quod, pers. comm.). Information for the coastal areas of Africa remains scarce, except for the coasts of Zanzibar and Tanzania where microalgal surveys were conducted as early as 2003 (Lugomela, 2006; Kiteresi et al., 2013). It should be noted that for many years, most of the published records available for the Indian Ocean concerned mainly G. toxicus, and were based solely on light or scanning electron microscopy observations (Bagnis, 1980, 1988; Quod et al., 1990; Thomassin et al., 1992; Grzebyk et al., 1994; Quod, 1994; Turquet et al., 1998; Hansen, 2001). Subsequent morphotaxonomic studies have revealed the presence of two additional species in various locations of the Indian Ocean: F. yasumotoi and/or G. belizeanus have been found in La Réunion, Saudi Arabia and the Marginal Seas (Red Sea, Gulf of Aqaba, Arabian Gulf) (Munir et al., 2011; Saburova et al., 2013; Catania et al., 2017). Of note, the molecular confirmation of the presence of G. australes and G. belizeanus has been provided recently by Chomérat et al. (2008) and Lavenu et al. (2018) in the Glorieuses and Seychelles, respectively (S1 and references therein).

In newly affected areas such as the Macaronesian region, the first reports of $\mathrm{CP}$ incidents were consistent with the concurrent reports of Gambierdiscus spp. in the Canary Islands and surrounding adjacent islands (Aligizaki and Nikolaidis, 2008; Fraga et al., 2011; Fraga and Rodríguez, 2014), as well as in Madeira (Reverté et al., 2018). In this respect, the Canary Islands have a remarkably high diversity of Gambierdiscus species, with the description of as many as five CTX-producing species: G. australes, G. caribaeus, G. carolinianus, $G$. 
excentricus, and G. silvae, plus a putative new species, Gambierdiscus ribotype 3 (Fraga et al., 2011; Fraga and Rodríguez, 2014; Pisapia et al., 2017a; Rodríguez et al., 2017; Reverté et al., 2018) suggesting an ancient settlement of Gambierdiscus populations in the Macaronesia region (Rodríguez et al., 2017) (S1).

Toxicity of Gambierdiscus and Fukuyoa differs widely within and among species (Chinain et al., 1999; Chinain et al., 2010; Litaker et al., 2017). Since CP occurrence is generally associated with complex assemblages of multiple Gambierdiscus/Fukuyoa species, it has been suggested that ciguatoxicity in a given area depends primarily on the presence of selected highly toxic species of Gambierdiscus that may not be the numerically dominant species but, which contribute disproportionately to the overall flux of CTXs in the environment (Litaker et al., 2010; Litaker et al., 2017; Longo et al., 2019). In this regard, G. polynesiensis appears to be the major toxin producer in the Pacific Ocean (with a wide geographic distribution there (Chinain et al., 2010; Rhodes et al., 2014; Smith et al., 2017; Darius et al., 2018a; Longo et al., 2019), while G. excentricus, G. australes, and possibly G. silvae, fill that role in the Atlantic (Fraga et al., 2011; Pisapia et al., 2017b). Figure 1B illustrates the current distribution of these "hot" species. However, it cannot be excluded that other species with lower ciguatoxicity (i.e., toxin production ranging from several femtograms to sub-picograms cell ${ }^{-}$ ${ }^{1}$ ), but wide geographical distribution, may significantly contribute to the bioaccumulation of CTXs in marine food webs as well, as is the case for certain strains of G. pacificus and $G$. australes (Fig. 1B) (Litaker et al., 2017; Pisapia et al., 2017a; Reverté et al., 2018). Of the known toxin producing Gambierdiscus species, G. australes may prove to be one of the most challenging to understand. Its toxin values are generally lower in the Pacific than those reported from the Atlantic (Reverté et al., 2018; Tester et al., 2020a), and while widely distributed elsewhere, G. australes has not yet been recorded from the Caribbean (Tester et al., 2020b). 
Depth is also another important consideration relating to Gambierdiscus and Fukuyoa spp. distribution. Given that certain Gambierdiscus species are more toxic than others, it is likely that depth distribution could affect the source of CTXs in the food webs as depth is autocorrelated with decreases in temperature, and several of the more toxic species have lower thermal tolerance (Quod, 2020; Tester et al., 2020a, for a review and references therein).

\section{Ciguatera Poisoning: clinical features and atypical forms}

\subsection{Clinical features of Ciguatera Poisoning}

There are currently no identified biomarkers that can be used to confirm exposure to ciguatera toxins in humans. Ciguatera diagnosis is based on the clinical scenario and the patient's recent fish-eating history (Friedman et al., 2017). Clinically, this disease is characterized by a complex combination of aspecific symptoms and signs. Up to 175 different symptoms have been recorded in both the acute and chronic phases of the illness (Wang, 2008). These symptoms include gastrointestinal (diarrhea, nausea, vomiting, abdominal pain), cardiovascular (bradycardia, hypotension) and neurological disturbances (circumoral and general paresthesia, dysesthesia, such as cold allodynia, itching, muscle weakness, asthenia), appearing within 48 hours after the ingestion of a toxic meal (Friedman et al., 2017). While gastrointestinal and cardiovascular manifestations generally subside spontaneously within few days, some of the symptoms, mainly neurological (paresthesia, dysesthesia, asthenia, neurocognitive disorders) and psychiatric (anxiety, depression) can last for months or even years in chronic and relapsing cases ( $>20 \%$ of patients) (Lawrence, 1980; Blythe, 1992a; Blythe, 1992b; Katz et al., 1993; Pearn, 1996; Arena et al., 2004; Chateau-Degat et al., 2007; Bailey and Withers, 2014; Stempf, 2015; Gatti et al., 2018). In addition, CP symptoms can be revived by the repeated consumption of certain marine related products (even those containing no traces of CTXs), meats, nuts, alcohol, or under specific circumstances such as intense 
physical activity, temperature variations or stress (Lange et al., 1992; Fleming, 1997; Lewis, 2001; Gatti et al., 2018). Chronic CP manifestations and peaks of recurrences may vary in intensity and duration from an individual to another, and no predisposing factor has been clearly identified, as yet. Overall, the effective management of ciguatera patients is significantly hampered by the lack of a specific antidote, and medical management of acute and chronic ciguatera in affected patients relies mainly on case by case symptomatic support, and diet recommendations (Friedman et al., 2008). Ciguatera-related fatalities are rare $(<0.1 \%$ of reported cases, with only one fatality in the USA in 20 years and only one every 10 years in Australia) (Lehane and Lewis, 2000), although this affliction is characterized by a high morbidity rate. Fatalities have been reported from the Pacific, Caribbean and Indian Ocean regions (Chan, 2016) and result mainly from severe central nervous system dysfunction and/or cardiovascular decompensation, often aggravated by late or insufficient medical assistance. Chan (2016) has identified several contributory factors to ciguatera-related deaths, including consumption of large portions of fish parts rich in CTXs (e.g., viscera and head), fish species known to be at high risk of ciguatera (e.g., moray eels), and each individuals' susceptibility.

The symptomatology of CP cases reported from the Southwest Indian Ocean (SWIO) region is similar to the one described in the Pacific, except for additional signs such as hallucinations and higher fatalities (Quod and Turquet, 1996). It has been hypothesized that such symptomatology may actually reflect potential contamination of (herbivorous) fish flesh by neurologically active compounds associated with ichthyoallyeinotoxism (de Haro et al., 1997), a mild form of fish poisoning characterized primarily by hallucinations and nightmares well known to local fishermen in Mauritius and La Réunion (Lebeau, 1979; Quod and Turquet, 1996). Moreover, other forms of poisoning can present certain features that may be similar to that of $\mathrm{CP}$, such as paralytic and neurotoxic shellfish poisoning, pufferfish and scombrotoxin fish poisoning, as well as botulism, enterovirus infection, bacteremia, and even 
organophosphate pesticide poisoning (Zlotnick et al., 1995; Caplan, 1998; Ting and Brown, 2001). All these observations stress the importance of a thorough, differential diagnosis when investigating fish-borne poisoning incidents, especially those occurring in regions with overlapping occurrences of ichthyoallyeinotoxism and/or involving marine products not specific to ciguatera poisoning (Zlotnick et al., 1995; Ting et al., 1998; Raikhlin-Eisenkraft and Bentur, 2002; de Haro et al., 2003; El Masry and Fawzi, 2011; Gatti et al., 2018).

Identifying and quantifying CTXs in blood samples recovered from affected patients can help support the clinical diagnosis of ciguatera. Only two studies aiming at evaluating the relevance of different analytical tools to detect acute ciguatera poisoning in human blood are documented in the literature. In Puerto Rico, a pilot study aiming at quantifying CTXs in blood samples recovered from affected patients was conducted among 11 asymptomatic vs. 86 patients who presented with ciguatera symptomatology in emergency units within $24 \mathrm{~h}$ of fish consumption. Results showed that $40 \%$ of ciguatera patients had blood concentrations three standard deviations above asymptomatic negative controls (Matta et al., 2002). In the Philippines, Mendoza et al. (2013) screened the blood samples of 22 patients with classic ciguatera symptoms, using electrospray ionization mass spectrometry. The presence of CTXs corresponding to the masses of P-CTX1B and P-CTX3B/3C was confirmed in blood samples of some patients. These findings highlight the relevance of this approach for more effective management of $\mathrm{CP}$ cases.

In any case, the lack of biomarkers to confirm $\mathrm{CP}$ diagnosis in humans and the failure by health professionals to achieve proper differential diagnosis in patients clearly emphasizes the urgent need to reach consensus on a refined, universal case definition of CP to help identify cases consistently (Friedman et al., 2017).

\subsection{Atypical forms of Ciguatera Poisoning}




\subsubsection{Shark poisoning: an atypical form of Ciguatera Poisoning in the Indian Ocean}

Severe food poisoning following the consumption of sharks has been recognized since the 1940 s and is generally characterized by a high mortality rate ranging from $11 \%$ to $30 \%$ depending on the studies and shark species involved (Habermehl et al., 1994; Boisier et al., 1995; Diogène et al., 2017). Shark poisonings occur mainly in the Indian Ocean and the Pacific Ocean regions (Le Bouquin et al., 1993; Habermehl et al., 1994; Boisier et al., 1995; Gatti et al., 2008; Diogène et al., 2017). For many years, there was no clear understanding of their cause. From traditional Polynesian cultural knowledge, Gatti et al. (2008) concluded that shark poisoning should not be ruled as CP-like poisonings owing to the frequent observations of cardiovascular and unusual neurological signs. Similarly, in Australia, a study which examined the flesh and liver from 22 sharks representing nine species for the presence of CTX-like compounds lead to inconclusive results with respect to the potential bioaccumulation of CTXs in sharks (Meyer et al., 2016).

There have been other attempts to identify the source of toxins involved in shark poisonings. In 1994, following a mass, fatal outbreak in Manakara (Madagascar, Indian Ocean) associated with the consumption of a single shark (Carcharhinus leucas or $C$. amboiensis), toxicological investigations conducted on liver samples failed to confirm the presence of CTX-like compounds. Instead, it was suggested that two new toxins named "carchatoxin A" and "carchatoxin B" possibly could be involved (Yasumoto, 1998). Consequently, carchatoxism was proposed as a novel form of ichtyosarcotoxism specific to the south western Indian Ocean. Since then, numerous outbreaks have been reported exclusively from Madagascar, whereas Comoros, Mauritius, Seychelles and east African coasts, are apparently free of this seafood poisoning despite that sharks are regularly consumed in these countries. A major breakthrough in the understanding of the sources of toxins in this singular form of poisoning was recently achieved following a severe, fatal 
poisoning in November 2013 in Madagascar. It affected 97 people and resulted in 11 fatalities. Patients presented with ciguatera-like symptoms after eating the flesh, liver, and head of a single C. leucas shark individual (Diogène et al., 2017). Chemical investigations further conducted on tissue remnants of the implicated shark (flesh, stomach, and fins) confirmed the presence of high CTX-like activity in all tested samples, as well as the detection of I-CTX analogs in the stomach extract. The concurrent detection of gambieric acid D from flesh tissue, a compound originally described in cultures of CTX-producing Gambierdiscus spp. (Nagai et al., 1992), allowed confirmation that consumption of sharks from the Indian Ocean should be considered an ongoing ciguatera risk. Madagascar is not currently recognized as a $\mathrm{CP}$ endemic area. So this finding warrants immediate actions to evaluate the magnitude and risk posed by the consumption of local sharks. Too, clarification of the exact nature of the source-organism of carchatoxins previously characterized in these atypical vectors of $\mathrm{CP}$ is necessary.

\subsubsection{Marine invertebrates as novel vectors of Ciguatera Poisoning in the Pacific and}

\section{Caribbean regions}

Several studies conducted in well-known ciguatera hot-spots of the Pacific and the Caribbean have recently provided evidence that a variety of marine invertebrates currently harvested for both subsistence use and commercial markets by local communities may occasionally be involved in CP-like incidents.

Poisoning events implicating the giant clam Tridacna maxima have been documented in French Polynesia, New Caledonia, and the Cook Islands (Laurent et al., 2012). Of note, the atypical clinical features reported in New Caledonian patients (e.g. rapid onset of the disease within minutes after the ingestion of toxic meal, paralysis, with one third of patients requiring hospitalization), together with the apparent absence of Gambierdiscus populations in the 
suspected fishing site led the authors to speculate that benthic marine cyanobacteria could be involved as the main toxin producers (Laurent et al., 2008; Laurent et al., 2012).

Toxic incidents following the ingestion of sea urchins, Tripneustes gratilla and Tripneustes esculentus also have been reported from French Polynesia and the West Indies, respectively (Randall, 1958; Pawlowiez et al., 2013; Darius et al., 2018b). In the case of T. gratilla-related poisonings, a combination of gastrointestinal, neurological, and general disorders was experienced by all patients (Gatti et al., 2018).

More recently, in 2014, nine tourists simultaneously developed a severe poisoning syndrome following the consumption of gastropods, Tectus niloticus, collected from Nuku Hiva Island (Marquesas, French Polynesia) (Gatti et al., 2018). Most of these patients presented with gastrointestinal, neurological, and cardiovascular symptoms, and were initially hospitalized, with some of these symptoms persisting for months (Gatti et al., 2018). Interestingly, toxicological analysis further performed on both T. gratilla and T. niloticus specimens collected from the same implicated toxic site of Anaho Bay in Nuku Hiva Island confirmed the presence of high CTX contents in these toxic samples (Darius et al., 2018a; Darius et al., 2018b). Moreover, the toxin profiles detected in these samples suggested that Gambierdiscus was the likely source of the CTXs compounds naturally bio-accumulated in these marine invertebrates. Sporadic poisoning cases involving octopus (Octopus cyanea) crabs (Percnon spp.) and worm shell (Dendropoma maxima) have been reported in the Cook Islands (Rongo and van Woesik, 2011). In the Republic of Kiribati, the presence of CTXs was confirmed in lobsters (Panulirus penicillatus) and octopus (Mak et al., 2013). A recent study in Cuba coral reef ecosystem which included the occurrence of CTXs in marine invertebrates, showed that the sea urchin Diadema antillarum and the lobster P. argus were positive for CTXs (Díaz-Asencio et al., 2019a). Of note, spiny lobsters (Palinuridae) are known to be 
natural predators of sea urchins such as D. antillarum in the Caribbean (Kintzing and Butler, 2014), suggesting CTX transfer through marine invertebrates food web also takes place.

These observations confirm that several species of marine invertebrates highly prized by island communities in the Pacific and the Caribbean also represent a potential risk for human consumption. Since most ciguatera risk assessment and management programs currently rely solely on the monitoring of CTXs in fish, this underscores the importance of extending such surveys to other organisms that are most representative of tropical food webs

\section{Global prevalence of Ciguatera Poisoning}

3.1 Current gaps and weaknesses in collection of CP epidemiological data

The large discrepancy observed in annual estimates of worldwide ciguatera cases among studies clearly reflects the uncertainty around the true impact of ciguatera (Lewis and Sellin, 1992; Quod and Turquet, 1996; Fleming et al., 1998; Lewis, 2001; Pearn, 2001). Global efforts to capture incidence rates of $\mathrm{CP}$ are significantly hampered by two major issues. The first is the lack of a diagnostic standard and /or lack of recognition of CP symptoms by medical practitioners, most notably in non-endemic areas. This leads to frequent misdiagnoses and misclassification of $\mathrm{CP}$, both clinically and in public health statistics, resulting in inaccurate estimation of prevalence and incidences of CP results (Pearn, 2001; Friedman et al., 2017). In 1982, one of the first attempts to educate the physicians in the United States about ciguatera was an article published in the American Journal of Public Health entitled: "Physicians: Know Thy Ciguatera Symptoms!" (Dembert and Pearn, 1982). Most notably, the worldwide increase of international exports of large exotic fish from endemic areas to non-endemic (temperate) countries stresses the importance for medical staff to consider CP as a diagnosis, even in the absence of a prior history of travel by patients (Freudenthal, 1990; Bruneau et al., 1997; Epelboin et al., 2014). Even though defining ciguatera in terms of a small, reliable group of 
symptoms remains difficult (see section 2.1), some clues should be regarded as strong indicators of $\mathrm{CP}$ especially if two or more consumers of fish at the same meal experience symptoms. Highly evocative of CP are complainants of cold allodynia especially after eating the head or offal of fish (Edwards et al., 2019).

The second cause of the underestimation in $\mathrm{CP}$ prevalence is a nearly universal underreporting of $\mathrm{CP}$ cases to national health organizations in most of the affected areas. Ciguatera is estimated to be under reported by as much as $90 \%$ with records supporting as many as 500,000 affected people annually (Friedman et al., 2008). In the Caribbean islands, it is estimated that only $0.1 \%$ or fewer poisoned persons consult a physician (Tosteson, 1995), while in the south Pacific, reported CP cases likely represent only $20 \%$ of the actual cases (Skinner et al., 2011). Chief among the many causes of poor reporting are: (i) the failure by consumers to recognize or seek treatment for $\mathrm{CP}$, and (ii) the fact that reports of $\mathrm{CP}$ events by health professionals are still made on a voluntary basis even in CP-endemic countries. There is a generalized reticence to consult a medical staff for a ciguatera in endemic regions (e.g., within island communities) since many patients tend to rely on traditional medicine for treatment (Bourdy et al., 1992; Kumar-Roiné et al., 2011). According to Farstad and Chow (2001), mild cases in endemic areas are rarely reported. In the Caribbean islands, there is a very casual attitude toward $\mathrm{CP}$ and many residents understand the risk of $\mathrm{CP}$ when they choose to eat certain species of fish and suffer the "flu" (Nicholas, pers. comm.). A ten year summary of trends in non-communicable disease mortality in the Caribbean makes no mention of CP and $\mathrm{CP}$ is not included in the Caribbean Health Agency's (CARPHA) Summary of the Regional Health Framework 2016-2025 (Razzaghi et al., 2019).

Ciguatera is not a notifiable disease in most countries so reporting CP incidents is optional, based on the goodwill of medical staff (Freudenthal, 1990; McKee et al., 2001; Goater et al., 2011). To date, mandatory reporting of ciguatera is only required in the USA, Australia 
(ciguatera is only notifiable in the Northern Territory and Queensland), Fiji, Canada, and Hong Kong. In the Caribbean, only three jurisdictions have mandatory reporting requirements (Puerto Rico, US Virgin Islands and Belize) and the knowledge and/or concern about CP varies widely throughout the region (Tester et al., 2010). In many other countries, CP incidents are merely reported at local levels (e.g., local authorities' statistics or websites, workshops or local newspapers). Table 1 lists a number of website links used to access the CP epidemiological data presently available.

A prominent issue in assessing of the true burden of ciguatera is lack of standardization in data collection methodologies, detection of affected populations and different timelines. These factors make it difficult to compare incidence data across regions and datasets. By way of example, validated CP data from the Centers for Disease Control and Prevention (CDC, S2) and self-reports of CP from the Poison Control Center (PCC) (Gingold et al., 2014) both provide a context for CP outbreaks in the USA (Figure 2A-B). The CDC data for 1998-2017 include the USA, Puerto Rico and Guam (with one fatality in 1999) (Fig. 2A), while the PCC data for 2001-2011 are gathered from the USA, Puerto Rico and the US Virgin Islands (Fig. 2B). Although both datasets show the highest numbers of CP cases between 88 and 137, and record lower numbers of CP illnesses in the same period (2004-2005), they are not directly comparable as they represent slightly different geographic regions and reporting practices (data vetted by the CDC vs. self-reporting via a telephone "hot" line). Likewise, studies based only on emergency room reports of CP (Morris et al., 1982; Radke et al., 2013) likely tell only part of the story as most Caribbean $\mathrm{CP}$ victims forgo treatment.

Another important consideration likely to affect the accuracy of $\mathrm{CP}$ data concerns the way incidence rates (IRs) are expressed. While small islands in the same geographic area may provide comparable data, it is clear data from larger regions normalized to entire populations, both coastal and interior will mask the CP problem. For instance, IRs of ciguatera for coastal 
counties of Florida (Monroe County and the Florida Keys) are many fold higher than when CP data are normalized using the population of the entire state (Radke et al., 2015).

Finally, when CP outbreaks present as large disease clusters due to group consumption of a single contaminated fish, as is commonly observed in the Indian Ocean and in east and southeast Asia, CP prevalence can be significantly underestimated, again, since many of the poisoned persons do not tend to report their poisoning.

\subsection{Incidence rates of $\mathrm{CP}$ in historical endemic regions}

Ciguatera poisoning rates are reported in the Pacific, Caribbean, and east/southeast Asia regions, before and after 2008 (Table 2).

In the Pacific region, annual IR data were obtained mainly through the implementation of the South Pacific Epidemiological and Health Information Service (SPEHIS) until the 2000s (Australian Institute of Marine Science (AIMS), 2009). Although this system was initially successful in collecting $\mathrm{CP}$ data, the contribution of participating countries progressively stopped due mainly to the fact that providing data was voluntary. Consequently, over the past ten years, a significant decrease in data collection is observed in the Pacific. To date, accurate documentation of CP incidents in the Pacific region is achieved mainly in French Polynesia, Australia and Hawaii. However, since these countries manage independent surveillance systems for ciguatera that are not part of the PICT regional health information systems, ciguatera case history and outbreak data for the Pacific region remain inconsistent and fragmentary (Goater et al., 2011). As shown in Table 2, minimal and maximal IRs reported within the Pacific Countries may fluctuate significantly from year to year, from 0 to 3,600/100,000 inhabitants as is the case for the Cook Islands. However, whether these variations result from fluctuations in $\mathrm{CP}$ caused illnesses or from a default in data collection is not known. Based on data available since 2008, IRs reported from the Cook Islands, the 
Republic of Kiribati and Niue, may occasionally exceed 1,000/100,000 inhabitants. Despite this alarming situation, few countries in the Pacific region currently have a defined action plan in response to this $\mathrm{CP}$ health threat.

In French Polynesia, ciguatera is the main, if not only, cause of seafood poisoning (Gatti et al., 2008). Incidence rate data collected through a country-wide ciguatera epidemiological surveillance program established in collaboration with the Public Health Directorate of French Polynesia (Chinain et al., 2016) point toward a stable annual incidence rate around 158 per 100,000 inhabitants in French Polynesia as a whole over the past decade. However, rates can differ considerably from one year to another and from one island/island group to another. The highest IR ever reported was 17,500 cases per 100,000 inhabitants in the context of a mass CP outbreak in Rapa Island (Institut Louis Malardé (ILM), 2007-2018). As previously reported in other endemic locales in the Pacific, it is quite possible these figures could be three-fold higher. To help compensate for the fact that ciguatera reporting is not mandatory in this territory, a dedicated ciguatera website was built in 2014 (www.ciguatera.pf) in an effort to open the notification program to private practitioners and the general public.

With IRs that could occasionally reach 350 cases/100,000 inhabitants in the early 2000 s, CP is considered a "high priority" by the public health authorities of Fiji. Cases are notifiable under the National Notifiable Disease Surveillance System managed by the Ministry of Health and Medical Services of Fiji (Table 1). The country also has implemented response procedures where each case is subjected to an investigation. However, it should be noted that Fiji is presently experiencing a drastic drop in CP case numbers since 2009 (1,004 cases in 2008, then 0 cases between 2009 and 2011) (Skinner et al., 2011; Skinner, 2015), but it is unclear whether this decrease is a result of under-reporting or avoidance strategies by local communities. From 2009, CP annual prevalence has not exceeded 50 cases/ year in this territory. 
In Australia, the majority of CP events are recorded in the state of Queensland (Farrell et al., 2017). According to OzFoodNet, IRs recorded in this region range between 0.15 and 1.74 cases/100,000 inhabitants although they may occasionally reach 30 cases/100,000 inhabitants (Stafford, 2019), but it is estimated that official reports represent only $20 \%$ of actual cases (Lehane and Lewis, 2000; Nordström, 2013). In the tropical Northern Territory, CP cases are lower, likely due to sparser human population while further south, in New South Wales, there has been an apparent increase in CP from both imported fish and Spanish mackerel (Scomberomorus commerson) caught in the region's coastal waters (Farrell et al., 2017; Seger et al., 2019).

Ciguatera has a long history in the Caribbean Sea. As early as the mid-19th century, the Cuban government tried to mitigate ciguatera by enforcing regulation of commercial and recreational fishing including size restrictions on the catch and sale of as many as 20 species with barracuda (Sphyraena) chief among them (López, 1999) as cited in (Díaz-Asencio et al., 2019a). Celis and Mancera-Pineda (2015) reported 10,710 CP cases between 1980-2010 in the Caribbean, corresponding to an annual average IR of 42/100,000 inhabitants. A spatially extensive, Caribbean-wide survey (see Supplementary Information S3), and a site specific intensive door to door canvass of all households on Culebra found similar CP IRs for Puerto Rico and an adjacent island, Culebra. Azziz-Baumgartner et al. (2012) conducted a census of all occupied households on Culebra (340 households in 2005 and 335 households in 2006). They reported a CP incidence rate of 400 to 750 cases/100,000 inhabitants per year. This compared well to responses from a survey sent to health professionals and fishery officials in Puerto Rico resulting in IRs of 340-590 cases/100,000 residents per year (1996-2006) (Tester et al., 2010) (Table 2, S3). This equates to a $12-66 \%$ probability of a 60 -year-old Caribbean resident being affected some time in his or her lifetime. In the French West Indies (Guadeloupe), CP reports compiled from regional health authorities and two public hospital 
emergency rooms between 2013-2016 showed an annual IR of 14.7 cases/100,000 inhabitants, representing a five-fold increase compared to 1996-2006 (Boucaud-Maitre et al., 2018). Conversely, the US Virgin Islands, a hot spot for CP, is reported to have a stable or slightly declining CP rates between 1980 (1,400 cases/100,000 inhabitants) compared with 2010-2011 (1,200 cases/100,000 inhabitants) (Radke et al., 2013).

Reports of CP events in East/Southeast Asia remain scarce and are mainly reported by local media, health authorities' press release or annual reports. As shown in Table 2, only IR data from the Guangdong region (China), Hong Kong, Japan and the Philippines are currently available (Chan, 2014b; Chan, 2015c; Chan, 2015a). Of note, for all countries except Japan, these data date back to 2008. This gap in incidence information is all the more surprising considering the high interest in tropical fish trade and consumption in these countries. This clearly highlights that most health professionals and the public in this region remain largely unaware of this toxic threat. To date, no specific CP reporting system is established in this region, with the exception of Hong Kong where notification of $\mathrm{CP}$ is mandatory (Chan, 2014a), and where fish traceability was instituted in 2012 (Yau, 2012).

In the Indian Ocean, a regional ciguatera survey conducted in 1979 allowed confirmation that the Mascareignes archipelago (which comprises La Réunion, Mauritius, Rodrigues, and nearby offshore shoals of Saya de Malha, and Saint Brandon) was endemic for CP (Bagnis, 1980). In order to ban risky seafood, either imported or caught from coastal waters, from local markets, fish control programs and regulatory texts were then implemented in the region. As a result, epidemiological data started to be collected in La Réunion from 1988 to 1990 (Quod et al., 1990), and a regional database on seafood poisoning incidents was even set up in the framework of the ECOTOX program (1998-2004). La Réunion, Mauritius, and Madagascar also have more specific surveillance programs on seafood poisonings (e.g., epidemiology, characterization of fish species, toxin profiles involved in poisoning events) and HAB events. 
The estimated annual IRs reported in La Réunion during (1986-1996) and (2010-2015) periods were 8 and 3/100,000 inhabitants, respectively (Sève et al., 2011), and corresponded mainly to imported CP cases.

\subsection{Ciguatera Poisoning occurrences by region}

In this section, $\mathrm{CP}$ occurrences will be reviewed in different regions recognized as ciguatera-endemic areas, including Macaronesia and the Mediterranean Sea. Figure 3 shows the regions where $\mathrm{CP}$ occurrences have been documented at a global scale, overlaid with areas where toxicological investigations have confirmed the presence of CTXs in fish and/or marine invertebrates implicated in sporadic outbreaks, or analyzed in the frame of random fish testing surveys, as detailed in Table 3. Of note, the highest CTX levels measured in toxic meals were not always linked to severe CP cases or those which required patients' hospitalization, suggesting that each patient has a different exposure history and sensitivity to ciguatera (see Table 3 and references therein). These confirmatory analyses also provided data useful for the differentiation of ciguatoxin profiles in fish from one region to the next and the determination of toxicity thresholds (Dickey and Plakas, 2010). The guidance levels for CTXs in fish established by the US FDA are $0.01 \mu \mathrm{g}$ CTX1B eq $/ \mathrm{kg}$ in the Pacific and $0.1 \mu \mathrm{g} \mathrm{C}-\mathrm{CTX} 1 \mathrm{eq} / \mathrm{kg}$ in the Caribbean (US Food and Drug Administration (FDA), 2019), consistent with the European Food Safety Authority (EFSA) opinion which indicates that a fish CTX concentration of $0.01 \mu \mathrm{g} / \mathrm{kg}$ P-CTX1B, regardless of source, should not exert effects in sensitive individuals when consuming a single meal (European Food Safety Authority (EFSA), 2010).

\subsubsection{Pacific region}

According to Skinner et al. (2011), an estimated 500,000 people may have suffered from 
ciguatera in PICTs between 1973 and 2008. This represents a 60\% increase in the annual incidence of ciguatera between (1973-1983) and (1998-2008), based on PICTs that reported for both time periods.

Between 2000-2016, Fiji, French Polynesia, and The Republic of Kiribati recorded at least 8,715 cases (Skinner et al., 2011; Skinner, 2015), 8,046 cases (Institut Louis Malardé (ILM), 2007-2018; Château-Degat et al., 2009), and 6,400 cases (Skinner et al., 2011; Skinner, 2015); respectively, while the Cook Islands registered 2,961 cases (Iorangi and Nanai, 2017), Marshall Islands, 2,726 cases (Skinner et al., 2011; Capelle and Lemari, 2015), and Hawaii, 410 cases (Disease Outbreak Control Division- State of Hawaii, 2019). However, in these areas, the distinction between isolated $\mathrm{CP}$ cases and outbreaks is unclear. According to Stafford (2019), 81\% of the CP cases recorded in Queensland (Australia) between 2006 and 2015 happened in a context of outbreaks, while in French Polynesia, $41 \%$ to $60 \%$ of the cases recorded since 2015 were associated with outbreaks with multiple victims (Institut Louis Malardé (ILM), 2007-2018). Except for two circumscribed CP outbreaks observed in the 1950s (Quod, 2014) and early 1990s (Australian Institute of Marine Science (AIMS), 2009), CP was not considered a threat in Wallis and Futuna until 2010. Since this date, 97 cases were reported by health and veterinary authorities (i.e., 23 cases in 2010, 40 cases in 2011, 9 in 2012-2013, 6 cases in 2018 and 19 cases in 2019) (Quod, 2014; Brunet, 2015; Agence de santé de Wallis et Futuna, 2020) (pers. comm. Brunet 2018).

In Australia, the first suspected CP outbreaks were reported in the 1960s in Queensland (Tonge et al., 1967). Between 2000 and 2015, 97 outbreaks totalizing 426 victims have been recorded in this country (Farrell et al., 2017), with a majority of cases reported from the state of Queensland, i.e., 475 cases in 2000-2016 (Stafford, 2019). However, since 2015, there has been an apparent increase in CP incidents in the state of New South Wales (NSW) linked to both locally caught Spanish mackerels (Scomberomorus commerson) and fish imported from 
the tropics (Farrell et al., 2017). But, as highlighted by the authors, it is not clear whether CP incidents have occurred previously in this region and were not reported or misdiagnosed, or if ciguatoxic risk has gradually increased in recent years.

In the absence of human biomarkers to confirm $\mathrm{CP}$, the detection of CTXs in fish implicated in poisoning incidents is most useful to help confirm CP diagnosis (Friedman et al., 2017). Confirmatory analysis conducted on both fish remnants implicated in toxic incidents and wild fish specimens caught from the Pacific region highlighted a number of interesting findings, such as: (i) Pacific CTXs (e.g., P-CTX1, 2 and 3) were the most commonly observed toxins found in tested samples (Yogi et al., 2011; Mak et al., 2013) (ii) liver had significantly higher concentrations of toxins than flesh, (iii) in some instances, there appeared to be an association between the severity of illness and how fish meal was prepared and consumed (Edwards et al., 2019), (iv) despite the widely accepted assumption that larger fish have a higher proportion of toxins, correlation between CTX concentrations and fish size/weight remains dubious (see Table 3 and references therein).

\subsubsection{Caribbean region including the Gulf of Mexico}

According to Celis and Mancera-Pineda (2015) who reported 10, $710 \mathrm{CP}$ cases between 1980-2010 in the Caribbean, an increase in CP incidence has been observed during the last 31 years, mainly in the eastern Caribbean. These findings are consistent with those of Tester et al. (2010) and Gingold et al. (2014) whose model predicted 200-400\% increase in CP incidences over the coming century if the Caribbean warms as much as $2.5-3.5^{\circ} \mathrm{C}$. Data obtained by a regional program for foodborne disease (FBD) surveillance (CARPHA website, Table 1) also contributes evidence for the increasing trend of CP in the Caribbean. There, between 2005-2012, CP represented 25\% of all reported cases of FBD pathogens. More evidence of higher CP incidence rates in the eastern Caribbean is found in Guadeloupe (French 
West Indies) with the report of 234 CP cases between 2013-2016 (Boucaud-Maitre et al., 2018). These authors suggested both ocean warming and habitat destruction as potential causes of increased CP in the Caribbean. This coincides with marked increases in hurricane activity (five-fold intensification) between 1995-2001 that was predicted to persist through 2040 (Goldenberg, 2001). These findings contrast with the study by Radke et al. (2013) who found no increase in CP incidence in the US Virgin Islands over a 30-year time period despite rising seawater temperatures.

In Mexico, the most recent review of epidemiological records documents 25 outbreaks involving 464 cases between 1984-2013 (i.e., 14 incidents affecting 208 people in the Mexican Caribbean Sea area and 11 incidents involving 256 patients in the Mexican Pacific Ocean region) with a subset of ciguatera cases from the Mexico's Caribbean coast occurring before 1984 (Núñez-Vázquez et al., 2019). Carnivorous fish, such as snapper (Lutjanus sp.) and groupers (Epinephelus sp. and Mycteroperca sp.) in the Mexican Pacific (Baja California peninsula), and great barracuda (Sphyraena barracuda) and snapper (Lutjanus sp.) in the Mexican Atlantic (Gulf of Mexico and Caribbean Sea), were involved in all cases.

According to the US FDA, prior to 2008, in the Gulf of Mexico region, "ciguatera was not historically associated with fish captured in the northern Gulf of Mexico". In 2008, however, there was sufficient concern by the US FDA about CP to warrant a ciguatera toxin alert after 28 cases of CP were reported including several confirmed outbreaks in St. Louis and Washington, D.C. This alert warned seafood processors who purchased fish harvested in the northern Gulf of Mexico off the coast of Texas to update their Hazard Analysis Critical Control Point (HACCP) Plans after confirmed CP outbreaks were linked to fish caught in the area of concern. As a result, CP is now considered to be a food safety hazard "reasonably likely" to occur upon consumption of groupers (Serranidae), snappers (Lutjanidae), hogfishes (Labridae), amberjacks (Carangidae) and barracudas (Sphyraenidae) caught within $50 \mathrm{~km}$ of 
the Flower Garden Banks (Tester et al., 2013). A follow up study of Gambierdiscus species diversity in the Flower Garden Banks found six species, three of which are known to be toxic (Litaker et al., 2017) and with multiple species found in single samples (Tester et al., 2013) (S1).

In the USA, sporadic reports of $\mathrm{CP}$ outbreaks generally associated with imported seafood are supported by more systematic reporting, albeit still far from complete (Begier et al., 2006; Pennotti, 2013; Barrett, 2017). Ciguatera is responsible for the highest reported incidence of non-bacterial food-borne illness outbreaks attributed to finfish in the USA (Dickey and Plakas, 2010), with 94 outbreaks (418 cases) between 1970 and 1980, 129 outbreaks (508 persons) from 1983 to 1992 (Nordström, 2013), and 288 outbreaks (1,117 cases) between 1999 and 2017 (Centers for Disease Control and Prevention (CDC), 2018). Hawaii, Florida, and Puerto Rico, alone, were responsible for 83\% of the outbreaks between 1998 and 2017 (Centers for Disease Control and Prevention (CDC), 2018).

Toxicological investigations conducted in the Caribbean (West Indies) on meal remnants revealed the lowest level of CTX measured in fish implicated in CP events was $0.02 \mathrm{ppb} \mathrm{P}$ CTX1B eqv. (Hossen et al., 2015). Random fish testing surveys conducted in various locations (Guadeloupe, US Virgin Islands, Gulf of Mexico, Cuba) were useful to i) confirm Caribbean CTXs (C-CTXs) are the main analogs involved in CP events in the Caribbean (see Table 3 and references therein), ii) estimate the consumption risk linked to invasive lionfish in this region (Litaker et al., 2014; Robertson et al., 2014; Soliño et al., 2015; Hardison et al., 2016), (iii) examine the impact of human activity (production platforms) on $\mathrm{CP}$ trends (Villareal et al., 2007), and iv) demonstrate for the first time ciguatoxicity in herbivorous fish in the Caribbean (Díaz-Asencio et al., 2019a).

\subsubsection{East and southeast Asia regions}


Countries of the east and southeast Asian regions appear to be diversely affected by ciguatera events. Overall, three groups can be distinguished: i) countries with a long history of ciguatera such as Japan, China, Hong Kong, the Philippines and Taiwan; ii) countries where ciguatera has emerged only recently ( $>2000$ s), such as Vietnam, Indonesia, Malaysia, Macau, Thailand and South Korea; and iii) countries not yet affected by ciguatera incidents. In any case, $\mathrm{CP}$ outbreaks in this region share at least two common characteristics: they often present as large cluster cases resulting from group consumption of a single toxic fish, and the vast majority of outbreaks primarily involve carnivorous fish, e.g., in the Lutjanidae (snappers), Serranidae (groupers), Muraenidae (moray eels) and Labridae (wrasses) families (Chan, 2015a; Chan, 2015b).

Japan is a long-standing ciguatera hotspot in Asia, especially the southern islands where the first suspected cases were documented as early as 1930 (Oshiro et al., 2010; Yogi et al., 2013; Chan, 2015a; Fukuyo, 2018). Since then, at least 278 outbreaks have occurred in this country between 1930 and 2010, affecting a minimum of 1,404 persons. In Hong Kong, early records of CP outbreaks date back to the 1980s coinciding with the increasing interest of consumers for live reef fish. Since 1984, at least 393 outbreaks implicating at least 1,750 persons have been recorded. Hong Kong experienced a second prominent CP outbreak in 2004 (Wong et al., 2005). Nearly $90 \%$ of CP present events correspond to local cases, with the remaining 10\% involving fish imported mostly from mainland China and Fiji (Wun, 2017). In Taiwan and the Philippines, ciguatera is known from the late 1980s (Chan, 2015a; Tabbada, 2015; Azanza et al., 2019) (de los Reyes, pers. comm.).

Indonesia was considered free of ciguatera until recently when several poisoning incidents (five outbreaks implicating at least 77 people between 2015 and 2018) were reported from Bengkulu, West Java, Maumere, and Kendari regions (Putra, 2018). Of note, snappers imported from this country were also responsible for a CP outbreak in Germany in 2014. 
Toxicological analyses further confirmed the presence of CTXs in the implicated fish (Friedemann, 2019).

Similarly, no CP cases were known in Vietnam before 2008. Since then, at least eight outbreaks, affecting a minimum of 180 persons, have been recorded, consistent with the concurrent report of species of Gambierdiscus in Vietnamese waters (Ho and Bing, 2018). Based on liquid chromatography coupled to mass spectrometry (LC-MS/MS) analyses conducted on two locally caught specimens of L. bohar involved in CP cases in 2014 and 2016, it was concluded that the CTX profile in local red snappers is similar to those of ciguatera fish from Australia, Okinawa Islands (Japan), Kiribati and Hong Kong (Ha et al., 2018) (Table 3). Of note, CTX quantifications in toxic fish samples from Japan showed good consistency between toxin concentrations and fish size/weight, mostly in carnivorous fish (Oshiro et al., 2010), while detailed LC-MS/MS analysis of CTXs revealed regional differences and species-specific toxin profiles in fish collected from Japanese waters (Yogi et al., 2011; Yogi et al., 2014).

The first imported CP cases reported in Macau involved a humphead wrasse (Cheilinus undulatus) caught in Shenzen (China) in 2004, and a specimen of Epinephelus sp. in 2006 of unknown origin (GCS, 2004, 2006), while the first suspected local CP outbreak was linked to a grouper (Epinephelus sp.) consumed in a local restaurant in 2005 (GCS, 2005).

Only one isolated case of CP has been documented in 1984 in Thailand and concerned an Italian tourist who developed a polyneuritis following the consumption of fish of unknown origin (Sozzi et al., 1988). Since then, two suspected CP outbreaks that implicated six people have been reported in Bangkok and Phuket, in 2007 and 2009, respectively, although the origin of the fish was unclear (Saraya et al., 2014).

Malaysia has recorded its first CP events in 2010 (Chan, 2015a). Two additional CP outbreaks have been further reported in this country between 2017 and 2019 (Lim, 2018; Lee 
et al., 2019) and all of these events were associated with Lutjanidae consumption, with at least two outbreaks involving fish imported from China.

In contrast, no CP events have been reported so far from Brunei, Laos, Cambodia, and Myanmar (Burma), while the only known CP outbreak reported from Singapore, in 2000, implicated mackerels imported from Fiji (Chan, 2015a). Similarly, no CP outbreak is known from East Timor, although an isolated case has been suspected in Dili in 2000 (IDSEP, 2000).

\subsubsection{Indian Ocean region}

The Indian Ocean region is the site of various seafood poisonings, including ciguatera poisoning, shark poisoning, ichthyoallyeinotoxism, scombrotoxism, clupeotoxism, chelonitoxism, crab poisoning and shell poisoning (Jones, 1956; Lagraulet, 1975b; Stempf, 2015). So far, there is no evidence of the involvement of either herbivorous fish or marine invertebrates (e.g., giant clams or sea urchins) in CP incidents reported from the Indian Ocean. Based on the surveys conducted from 1995 to 2005, as many as 34 carnivorous fish species have been implicated in CP outbreaks reported from the Mascareignes archipelago (Quod and Turquet, 1996). In 1993, a mass-poisoning incident involving a shark supposedly caught in the coastal waters of La Réunion, but more likely imported from the east coast of Madagascar (Le Bouquin et al., 1993) has prompted the revision of existing regulatory texts to specifically address the issue of shark poisonings.

In La Réunion Island, a total of 375 cases of CP have been recorded between 1986 and 1994 (Quod and Turquet, 1996), and 150 cases between 2000 and 2010 (Stempf, 2015). Of note, Serranidae, Lethrinidae, Lutjanidae, and Carangidae accounted for 53\%, 12\%, 8\%, and 6\%, respectively, of CP cases reported from 1986 to 1994 (Quod and Turquet, 1996).

Ciguatera is regarded as endemic in Mauritius Island and Rodrigues where this phenomenon is well known to local fishermen who often reject suspect catches. However, the 
exact IRs in these localities are not known since outbreaks are merely notified as "food poisonings". Of note, one fatality was documented around 2000 in Rodrigues following the consumption of a grouper (Variola louti) by a child. The first identification of Indian ciguatoxins analogs, i.e., two major (I-CTX1 and 2) and two minor (I-CTX3 and 4) compounds, was achieved from confirmatory analysis conducted on toxic snappers (Lutjanus sebae, L. bohar) caught from Mauritius (Hamilton et al., 2002a; Hamilton et al., 2002b) (Table 3). Unlike P-CTXs and C-CTXs, the exact chemical structure of these compounds remains unresolved.

Multiple forms of severe seafood poisonings are reported from Madagascar, including shark poisoning, chelonitoxism, and clupeotoxism. Records of sporadic outbreaks caused by a sea snail (Strombus gibberelus) and mussels have also been documented from the southwest region of Toliara (Champetier de Ribes et al., 1997). A retrospective study conducted between 1993 to 1997 showed a total of 19 seafood poisoning events involving 1,000 people occurred in Madagascar during this five years' period (Champetier de Ribes et al., 1997), but only one outbreak involving a locally caught snapper (Lutjanus erythropterus) was conclusively linked to CP. In addition, Diogène et al. (2017) recently confirmed that consumption of sharks from Madagascar should now be considered a ciguatera risk, thus expanding the range of pelagic fish species that are involved in ciguatera in the Indian Ocean. These authors also found two new analogs (I-CTX5,6) in shark samples (see section III.2, and Table 3).

In southwest India, CP was not described until 2015 when two successive outbreaks involving red snapper (Lutjanus bohar, locally known as chempalli) occurred in Mangalore (Rajeish et al., 2016; Rajisha et al., 2017b). The first outbreak (June 2015) involved two individuals who became ill following consumption of a red snapper purchased from a local market (Rajeish et al., 2016), whereas the second outbreak (September 2016) affected $>200$ people (Karunasagar et al., 2018). The confirmation of the presence of CTXs in implicated 
fish samples was further provided using a variety of toxicity methods including mouse bioassay, cytotoxicity and receptor binding assays, and LC-MS/MS (Rajisha et al., 2017a; Rajisha et al., 2017b; Karunasagar et al., 2018) (Table 3). A large-scale testing survey conducted on 262 locally caught reef fish further allowed confirmation of CTX-like activity in two specimens of L. bohar as assessed by MBA (Rajisha et al., 2017b) (Table 3). Consequently, ciguatera is now considered an emerging hazard in this area although the formal characterization of the species of Gambierdiscus and CTX analogs involved has yet to be completed.

In contrast, all the countries bordering the Mozambique Channel (e.g. Mayotte, Comoros, Mozambique) including those in the east African coast are presently regarded as ciguaterafree areas. Interestingly, in Mayotte where no CP case is reported so far, a survey conducted in the context of a flare-up of Gambierdiscus following the major 1998 El Niño event and subsequent coral bleaching episodes, show no increase of CP risk in randomly tested fish and species commonly consumed by local residents (Quod et al., 2000; Turquet et al., 2001). In the Comoros archipelago, all seafood poisoning incidents reported so far have been linked to clupeotoxism. Although CP cases have been suspected in the Unguja Islands (Tanzania), no official reporting is currently in place there (Quod, pers. comm.). Similarly, no ciguatera cases are currently documented from the Maldives archipelago and Sri Lanka.

In the Seychelles, no additional poisoning incidents have been reported by national authorities or consumers since the first historical poisoning record linked to a specimen of Lutjanus gibbus caught in Amirantes plateau (Wheeler, 1953), whereas in the Chagos archipelago, sporadic poisoning cases involving Plectropomus specimens have been reported but due to the lack of detailed information, they were not vetted as CP cases (Lebeau, 1979). Likewise, areas located in the marginal seas of the Indian Ocean (e.g. Laquedives Sea) seem to be spared by ciguatera (Lagraulet, 1975a). One CP record involving a location in the Red 
Sea exists (de Haro et al., 2003), but the implicated fish was not confirmed as a locally sourced fish. A single outbreak resulting in one fatality has also been reported from Pakistan but again, the fish species involved and its origin could not be confirmed (Wasay et al., 2008).

\subsubsection{Eastern Atlantic Ocean and Mediterranean Sea}

The first CP event reported from the Canary Islands occurred in 2004 and involved five individuals who ate a $26 \mathrm{~kg}$ lesser amberjack (Seriola rivoliana) captured by sport fishing in Las Palmas. Analytical tests, including CBA-N2a and LC-MS/MS, confirmed the presence of CTXs in the suspected fish (Pérez-Arellano et al., 2005). This first CP notification prompted the implementation of the Epidemiological Surveillance System for Ciguatera Poisoning in the Canary Islands (SVEICC) launched in 2009. This program requires the compulsory notification to the Epidemiology and Prevention Service of the General Directorate of Public Health of all cases treated in healthcare centers with symptoms consistent with ciguatera (Nuñez et al., 2012). As a result, between 2004-2012, at least nine outbreaks involving approximately 90 individuals have been documented from both the Canary Islands (i.e., seven incidents in Tenerife, Lanzarote, Gran Canaria, 72 individuals) and the Madeira Archipelago (i.e., two incidents in the Selvagens Islands, 17 individuals) (Pérez-Arellano et al., 2005; Gouveia et al., 2009; Boada et al., 2010; Caillaud et al., 2010; Otero et al., 2010; Nuñez et al., 2012). Of note, all documented outbreaks in the Canary Islands area have been associated with the consumption of large amberjacks (Seriola spp.) captured by sport fishing or bought at local markets (Bravo et al., 2015), whereas 1,500 km south, in the Madeira Archipelago, $\mathrm{CP}$ outbreaks involved various fish species including both herbivorous (Sparisoma credence) and carnivorous fish such as Seriola spp. and Pagrus pagrus (Gouveia et al., 2009).

Large-scale testing surveys conducted in the Canary Islands, Madeira and the Selvagens Islands have confirmed the presence of C-CTXs in Seriola spp., although recent investigations 
showed bioaccumulation of CTXs in locally sourced fish of the Canary Islands is no longer limited to Seriola spp. but also concern dusky groupers and other carnivorous fish such as moray eels (see Table 3 and references therein). Toxicity data derived from these large-scale surveys were tentatively used to establish a predictive score of ciguatoxicity in fish. In the surveys conducted in the Canary Islands, factors such as fish species and weight, fishing area, fish activity (i.e. commercial vs. sport fishing), as well as the season of the year were determined as risk factors associated with the probability of catching fish containing CTXs (Bravo et al., 2015; Sanchez-Henao et al., 2019), while Mak et al. (2013) concluded that CTXs accumulation in predatory fish from Kiribati does not depend on fish lipid content.

The eastern Mediterranean basin is an unusual region for ciguatera poisoning, however, several cases of ichtyosarchotoxism have been reported in the eastern Mediterranean Sea since the 1970s, following the consumption of Siganus luridus (Raikhlin-Eisenkraft and Bentur, 2002) and salema (Sarpa salpa) (Spanier et al., 1989). In Egypt, reports on the occurrence of ciguatera cases (including several fatalities) since the 1980s until recently are found in the literature (Abd-Elhaleem and Abd-Elkarim, 2011; El Masry and Fawzi, 2011; El Masry and Tawfik, 2013). Recent poisoning cases with a hallucinatory component also were described in 1994 and 2002 in the western Mediterranean (de Haro and Pommier, 2006). These observations are consistent with the report of Gambierdiscus cells on various macroalgal species sampled in Crete in 2003, which constitutes the earliest record of this genus in the Mediterranean Sea (Aligizaki and Nikolaidis, 2008). Since then, Gambierdiscus has been documented repeatedly in the area $(2004,2005,2007)$ (Aligizaki and Nikolaidis, 2008). However, studies conducted on various rabbit fish (Siganus sp.) samples failed to unequivocally link these incidents to CP, since the presence of CTXs could not be confirmed (Bentur and Spanier, 2007). This raises concern for possible misdiagnosis of CP with other forms of ichthyosarchotoxism occurring in this area (Chevaldonné, 1990; de Haro and 
Pommier, 2006). For instance, it was suggested that previous poisoning cases linked to $S$. salpa consumption were in fact the result of these fish feeding on Caulerpa macroalgae and contaminated with caulerpenyne, a sesquiterpene with strong neurotoxic and deterrent properties (Paul and Fenical, 1986; Brunelli, 2000).

\section{Potential drivers of Ciguatera Poisoning trends}

Figure 4 provides a compilation of the time-series CP data available from 2000 to 2018 for a number of countries/regions where ciguatera is endemic. From these graphs, it can be concluded that none of these areas showed identical CP trends. This likely reflects that CP occurrences in a given region depend on data collection/reporting capabilities and a complex combination of trend drivers specific to each country, among which socio-cultural determinants, tourism and fish trade activities, and climate change play roles.

\subsection{Impact of socio-cultural determinants}

Dietary habits and lifestyle of communities in CP-endemic areas can significantly impact ciguatera trends. It is recognized that the highest prevalence of CP illnesses are reported from coastal communities because of their strong reliance on marine resources. Updated estimates of the annual fish consumption rates per region are $10.5 \mathrm{~kg}$ per capita in Latin America/Caribbean, $21.6 \mathrm{~kg}$ per capita in Europe, $24.1 \mathrm{~kg}$ per capita in Asia, with the highest records reported from the Oceania region and the Maldives (Indian Ocean) i.e., 50-110 kg per capita and $163 \mathrm{~kg}$ per capita, respectively (Food and Agricultural Organization of the United Nations (FAO), 2020; Food and Agricultural Organization of the United Nations (FAO) and World Health Organization (WHO), 2020). Ciguatera clearly represents a major threat to food safety and food security in PICTs (Bell et al., 2009; Rongo and van Woesik, 2012; Morin et al., 2016). In many Pacific island communities people often contract $\mathrm{CP}$ several times during 
their lifetime (as many as 10 to 20 times for some). For instance, a study conducted in 2005 in New Caledonia among 559 patients reported that $37.8 \%$ presented with a previous history of CP (Baumann et al., 2010). Likewise, recent data from the French Polynesia CP surveillance program showed that approximately $52 \%$ of people newly affected by $\mathrm{CP}$ had actually experienced at least one CP previously in their life (Institut Louis Malardé (ILM), 2007-2018). The same proportion was observed by Rongo and van Woesik (2011) in a survey conducted between December 2008 and January 2010 in the Cook Islands (Rongo and van Woesik, 2011). Repeated exposure to CP is common in the Caribbean as well. In a sitespecific study (US Virgin Islands), Radke et al. (2013) found 59\% of their respondents $(\mathrm{n}=339)$ experienced $\mathrm{CP}$ and $19 \%$ and $12 \%$ had multiple bouts, two and three episodes respectively. Ten percent reported four episodes of $\mathrm{CP}$ with 10 illnesses being the maximum

\subsection{Impact of climate change}

Multiple causes are believed to contribute to the current expansion of ciguatera to more temperate areas. Among them, global ocean warming attributable to climate change is often cited as a main driver of increased CP occurrences (Ruff, 1989; Hales et al., 1999; Villareal et al., 2007; Tester et al., 2010; Gingold et al., 2014). Cyclical weather patterns such as El Niño, associated with unusual warming of Pacific Ocean waters, have resulted in spikes of ciguatera cases in Kiribati, Western Samoa, Tuvalu and the Cook Islands (Hales et al., 1999). In these areas where food diversity is limited, increased coral bleaching events, cyclones and poor reef conditions due to global changes may act as additional risk factors (Skinner et al., 2011).

In southern California, a 1995 outbreak linked to groupers caught from the Baja California peninsula was arguably a result of El Niño phenomenon (Barton et al., 1995). Similarly, Gingold et al. (2014) found an association between CP incidence and warmer sea surface 
temperatures in the Caribbean basin. This observation parallels those of Tosteson (2004) who reported a seasonal correlation between the abundance of toxic, benthic dinoflagellates, the toxicity of barracuda, and incidences of CP in Puerto Rico from 1985 to 1988. This was followed by a gradual loss of seasonality and a significant increase in the number of toxic barracuda between 1990 and 2000 from the southwest coast of Puerto Rico. Tosteson (2004) argued these changes were due to increasing periods of elevated sea surface temperatures.

Traditionally, CP in the Caribbean Sea is managed by local knowledge of the fishermen who understand which reefs are ciguatoxic and the seasonality of CP. In a Caribbean-wide study conducted from 1996 to 2006 to examine the relationship between CP and sea surface temperatures, six of the seven highest $\mathrm{CP}$ incidence rates occurred in islands between $12.5^{\circ} \mathrm{N}$ and $25^{\circ} \mathrm{N}$ in the eastern Caribbean. The highest rates of $\mathrm{CP}(340-590$ cases $/ 100,000$ inhabitants per year) were found in the Lesser Antilles, the easternmost part of the Caribbean (Tester et al., 2010). These high CP incidence rates co-occurred with the warmest water temperatures in the Caribbean and where annual temperatures are least variable. This has significance for the Caribbean because local CP management, based in part on seasonality, may no longer be reliable due to changing environmental conditions. Predictions by the Intergovernmental Panel on Climate Change (IPCC) (2007) are for mean decadal rates of warming of $\sim 0.13^{\circ} \mathrm{C}$ from 2000 to 2029 , a $0.31^{\circ} \mathrm{C}$ increase from 2030 to 2059 , reaching $0.41^{\circ} \mathrm{C}$ during the years 2070 to 2099 in the Caribbean Sea. Unlike other regions, the Caribbean is expected to have a reduced seasonality in the coming decades.

Increased hurricane activity in the Atlantic Ocean severely impacts the Caribbean region, Gulf of Mexico and US South Atlantic Bight and the potential for CP. Damaged reef habitats are conducive to Gambierdiscus recruitment and higher incidences of CP (Lehane and Lewis, 2000; Skinner et al., 2011). A combination of increasing North Atlantic sea-surface temperatures and decreasing vertical wind shear is credited by Goldenberg (2001), for major 
increases in hurricane activity (compared to the base period 1971-1994) affecting the Caribbean through 2010-2040. Their prediction have been borne out (NOAA, National Hurricane Center, https://www.nhc.noaa.gov/data/\#tcr).

One possible explanation for the current global expansion of ciguatera is that climate change has likely provided favorable conditions for the migration and settlement of $\mathrm{CP}$ causative organisms in new areas, consistent with novel reports of Gambierdiscus and Fukuyoa spp distribution in temperate-like areas of the globe (Tester et al., 2013; Nishimura et al., 2016; Rhodes et al., 2017a; Rodríguez et al., 2017; Jang et al., 2018; Larsson et al., 2018; Tudó et al., 2018; Larsson et al., 2019). As an example, the average annual increases in seawater temperatures observed in both south-eastern Australia and New Zealand's coastal waters are consistent with the recent occurrence reports of both Fukuyoa and Gambierdiscus in the subtropical northern region of New Zealand and the Kermadec Islands (Rhodes et al., 2017a; Rhodes et al., 2017c; Rhodes and Smith, 2018; Rhodes et al., 2020)(Rhodes et al., 2017a; Rhodes et al., 2017c; Rhodes and Smith, 2018; Rhodes et al., 2020) and the more temperate waters of New South Wales (Australia) (Rhodes et al., 2020, and references therein). The case of Macaronesia might be somewhat different as it has been suggested that the high diversity of Gambierdiscus species found in this area might actually reflect an ancient settlement of this organism in the Macaronesia region (Rodríguez et al., 2017). Of note, the first report of Gambierdiscus (originally referred to as Goniodoma sp.) dates back to 1948, in Cabo Verde (Silva, 1956). Therefore, in the case of the Canary Islands, it is likely that global warming has provided favorable conditions for growth (blooms) of Gambierdiscus populations.

Based on water temperature projections over the coming century, a substantial shift in both the distribution and abundance of ciguatera dinoflagellates is to be expected (Parsons et al., 2010; Kibler et al., 2015), provided species-specific habitat requirements are met (e.g., temperature, suitable substrate, low turbulence, light, salinity, $\mathrm{pH}$ ) (Tester et al., 2020a). 


\subsection{Impact of tourism}

Increased international tourism (World Tourism Organization (WTO), 2017) and fish imports from endemic areas such as tropical and subtropical regions of the Caribbean Sea and Pacific and Indian Oceans, have contributed to wider distribution and increasing frequency of imported cases of this disease among seafood consumers in all climate zones (Lewis, 1986; Lange, 1987; Morris, 1990; Morris et al., 1990; Lange et al., 1992; Dickey and Plakas, 2010; Bravo et al., 2015; de Haro et al., 2020). According to Lange et al. (1992), the risk of travelers contracting CP in endemic areas "likely equals that of indigenous groups". Indeed, establishing random fish testing surveys on a regular basis in $\mathrm{CP}$-endemic island states to prevent outbreaks is unrealistic because it is beyond the capacity of most of these countries. Therefore, recurrent $\mathrm{CP}$ incidents in tourists traveling to these endemic areas may have deleterious effects on the economies of these countries which rely heavily on tourism revenue. For instance, tourism income amounts to $\$ 25$ billion per year in the Caribbean (Burke and Maidens, 2005; Celis and Mancera-Pineda, 2015).

The imported CP events and outbreaks reported in the literature between the early 1980s to present day are summarized in S2. For the majority of travelers, the greatest risk of contracting ciguatera will be from consuming groupers, barracudas, snappers, jacks, and humphead wrasses, although in many cases the fish species involved in the poisoning incidents was unknown. Of interest, in several examples, the importance of a good interagency (e.g., between implicated local, provincial/state and federal authorities) dynamics and communication was credited for the effectiveness of trace back investigations and management of poisoning incidents (Mattei et al., 2014; Muecke et al., 2015; Rebato et al., 2018). 


\subsection{Impact of fish trade}

Increased importation of fish from the tropics to industrialized countries or between countries within the same region (case of Asian countries) is responsible for the worldwide increase of imported cases of CP (S2).

In 2007, it was estimated that the European Union (EU) and the USA imported $>80 \%$ of their fishery products to meet consumer demand (Dickey and Plakas, 2010). In the USA only a small percent of imported fishery products originates from $\mathrm{CP}$ endemic areas $(2.4 \%$ from the islands of Oceania, 2\% from the tropical Atlantic including the Caribbean Sea) (National Marine Fisheries Service (NMFS) Washington, 2008). Of note, while the sale or trade of barracuda was banned early in the $20^{\text {th }}$ century in Dade County (Miami) Florida the first published record of a $\mathrm{CP}$ incident among people with no travel history occurred as early as 1980 and involved nine patrons of a Maryland restaurant who ate a grouper (Doorenbos, 1984). In the Indian Ocean, La Réunion and Mauritius started to experience several large CP outbreaks in the 1960s following the development of commercial fishing activities in the near offshore banks of Nazareth, Saint-Brandon, and Saya de Malha (Lebeau, 1979).

The case of Hong Kong is even more emblematic of the role played by fish trade in increased CP trends. In southeast Asia, CP was not originally considered a threat since CTXs had rarely been reported in fish from the northern South China Sea, but as more and more live reef fish from known hot-spots of ciguatera (e.g., the Indian Ocean and PICTs) were brought to Hong Kong markets, the number of reported CP cases, although likely underestimated, has increased accordingly (Sadovy, 1997) (S2). The demand for live fish in southeast Asia has grown rapidly since the late 1980s (Johannes and Riepen, 1995), especially in Hong Kong, Taiwan, and China, forcing these importing nations to seek sources well beyond the South China Sea (Sadovy, 1997). For example, by the 1990s, live food fish entering Hong Kong, came from as far west in the Indian Ocean as the Maldives and as far south and east as the 
Marshall Islands, Solomon Islands, Kiribati, Tuvalu, the Great Barrier Reef (Australia) and adjacent locales (Johannes and Riepen, 1995) that are known to be high-risk ciguatera areas (Wong et al., 2014). The species of fish being marketed, mostly top reef predators such as groupers (Epinephelus spp, Plectropomus spp, Cephalopholis argus, Variola louti), snappers (Lutjanus spp.) and wrasses (Cheilinus undulatus) have resulted in a steady increase in the number of reported CP cases in southeast Asia (Chan, 2013a, 2013b, 2014a; Chan, 2014b; Chan, 2015a; Chan, 2015b). In Hong Kong alone, two prominent outbreaks affecting more than 600 people were recorded in 1998 and 2004, caused mainly by fish imported from the western Pacific (Wong et al., 2005). Consequently, CP is now recognized as a prominent health issue in Hong Kong, and the Hong Kong Health and Food Safety authorities periodically issue warnings of the risk of CP (Sadovy, 1997; Yau, 2010). In parallel, decisions were also made to ban the import of marine products from at risk regions (Chan, 2000), to avoid eating large fish (>1.8 kg) and to reduce overall fish intake (Sadovy, 1998).

\section{Conclusions}

In the early 1990s, it was estimated that CP represented a potential threat for approximately 400 million people living in tropical and subtropical coastal regions (Glaziou and Legrand, 1994). In light of the current range expansion of CP to novel areas, as well as the increasing popularity of reef fish in international (temperate) markets, the current number of people at risk should be examined and accurately evaluated. Gaining an accurate knowledge on CP global prevalence is therefore useful to inform public health interventions in order to limit the health and socio-economic impacts of this toxic threat. However, this review has highlighted the current inefficiency, on a global level, of existing reporting systems in collecting, collating, and communicating ciguatera data. While the expansion of CP to novel areas of the globe is now well established since the 2000 s, it is not possible, with any great certainty, to ascertain 
whether there has been a global increase in $\mathrm{CP}$ occurrences over the past decade, because $\mathrm{CP}$ cases are inconsistently reported. In CP-endemic countries, despite the very high IRs of this disease, ciguatera remains dangerously under-recognized by most national governments due mainly to a lack of resources and competing health priorities (e.g., non-communicable diseases). For example, the CARPHA established by the Caribbean Community (CARICOM) Caribbean Cooperation in Health Phase IV (CCH IV), Summary of the Regional Health Framework 2016-2025, does not include ciguatera poisoning (Razzaghi et al., 2019). In this forward-looking, decadal document, an important opportunity to address under-reporting of $\mathrm{CP}$ in the Caribbean has been neglected.

In an effort to implement a proactive surveillance of this disease at a global level, the critical issue of educating the medical community and the general public needs to be addressed as a priority. Relevant measures need to be taken to promote heightened awareness of the problem to allow both early recognition of clinical symptoms of ciguatera and improved patient care followed on by accurate, timely reporting (Thompson et al., 2017). Adopting a consensus case definition of $\mathrm{CP}$ to account for the variability in symptom presentation across different geographic regions appears a prerequisite. Establishing standardized case investigation forms may also help improve the data quality and characterize the epidemiology of ciguatera more accurately. Moreover, increased efforts to link patient data to CP toxicological reports in a single database will hopefully help prevent unnecessary investigations and morbidity in affected patients. There is currently no regional data platform to collate epidemiological data gathered from health care professionals, laboratory results and/or the public, an issue that urgently needs to be addressed as well.

International initiatives for increased, coordinated efforts in ciguatera education, monitoring, and research are being addressed by several international agencies. The IAEA Technical Cooperation in partnership with RAMOGE (www.ramoge.org), the 
Intergovernmental Oceanographic Commission of UNESCO, the Food and Agriculture Organization (FAO), the World Health Organization (WHO), the Scientific Committee on Oceanic Research on Harmful Algal Blooms in collaboration with (IOC-SCOR Global HAB) and the National Oceanic and Atmospheric Administration (NOAA) have come together with coastal managers and scientists from Asia-Pacific, Africa, Latin America, and the Caribbean to develop monitoring plans, identify gaps to detect toxic ciguatera causing dinoflagellates and monitor toxins (Tester et al., 2018). An epidemiology module was also included in the workshop to help increase recognition and reporting of $\mathrm{CP}$ victims. In the Pacific, recent initiatives such as the Pace-Net Plus project funded by the European Commission to reinforce EU-Pacific cooperation on Science, Technology, and Innovation (Pace-Net Plus website, Table 1), and the Safefish National Ciguatera Poisoning Research Strategy (Safefish website, Table 1), have recently emerged and could, hopefully, assist Pacific countries in setting up their own surveillance and management programs.

It is also highly encouraging that at the $32^{\text {nd }}$ Session of the Codex Committee on Fisheries and Fishery Products (Food and Agricultural Organization of the United Nations (FAO), 2016), CP was raised by the Pacific Nations as an issue that increasingly affects the tropical and subtropical regions of the Pacific Ocean, Indian Ocean, and Caribbean Sea. This prompted the Codex Committee to request FAO/WHO for scientific advice, and resulted in the FAO/WHO call for data and expert meeting on Ciguatera, in 2018 (Food and Agricultural Organization of the United Nations (FAO) and World Health Organization (WHO), 2020). It was noted that environmental changes, some closely associated with climate change, like the increasing frequency of storms and hurricanes as well as rising sea surface temperature impact the distribution and proliferation of ciguatoxins and make the occurrence of CP less predictable. Both the World Health Organization (WHO) and the Food and Agricultural Organization (FAO) of the United Nations recognize that globalization of trade and climate 
change may lead to the presence of ciguatoxins over a wider geographical area, and understand that further guidance may be needed for those countries that have not considered ciguatoxins in their risk management programs in the past.

\section{Acknowledgments}

Program funds from the Country of French Polynesia supported MC, CMG and HTD. Ocean Tester, LLC provided support for PAT. The authors thank N. Oshiro and J. E. ManceraPineda for providing supplementary data for Japan and the Caribbean respectively. They also gratefully acknowledge the two anonymous reviewers whose comments significantly helped improve the manuscript. Finally, the authors wish to pay tribute to all the pioneers in ciguatera research whose leading and dedicated efforts contributed to pave the way for young researchers.

\section{Figure captions}

Fig. 1: Global distribution of A) ciguatera-related Gambierdiscus and Fukuyoa genera, and B) CTX-producing species G. australes, G. excentricus, G. pacificus, G. polynesiensis, and G. silvae.

Fig.2: A) Ciguatera related phone calls to the Poison Control Center for the 48 contiguous United States of America, Puerto Rico and the US Virgin Islands (Gingold et al., 2014; Parsons and Richlen, 2016); B) Ciguatera related illnesses, outbreaks and hospitalizations for the United States of America, Puerto Rico and Guam from 1998-2017 (CDC website, Table 1). The CDC defines outbreaks as "the occurrence of cases of disease in excess of what would normally be expected in a defined community, geographical area or season. An outbreak may 
occur in a restricted geographical area or may extend over several countries. It may last for a few days or weeks, or for several years."

Fig.3: Areas with at least one local CP case reported (red), CTXs confirmation in locally caught fish (orange) and marine invertebrates (yellow)

Fig.4: CP cases (histogram) and number of outbreaks (curves) reported between 2000 and 2018 in French Polynesia, Cook Islands, Hawaii, Queensland (Australia), Caribbean (light green), Mexico (dark green), Okinawa (Japan), Hong Kong, and Canary Islands. Data extracted from (Pérez-Arellano et al., 2005; Institut Louis Malardé (ILM), 2007-2018; Oshiro et al., 2010; Lin and Hwang, 2012; Celis and Mancera-Pineda, 2015; Iorangi and Nanai, 2017; Wun, 2017; Disease Outbreak Control Division- State of Hawaii, 2019; Núñez-Vázquez et al., 2019). Produced with help of Naomasa Oshiro and J. Ernesto Mancera-Pineda who provided supplementary data for Japan and the Caribbean, respectively 


\section{BIBLIOGRAPHY}

Abd-Elhaleem, Z., Abd-Elkarim, M., 2011. Pattern of food poisoning in Egypt, a retrospective study. J. Pharmacol. Toxicol. 6(5), 505-515.

Adachi, R., Fukuyo, Y., 1979. The thecal structure of a marine toxic dinoflagellate Gambierdiscus toxicus gen. et sp. nov. collected in a ciguatera-endemic area. Bull. Jpn. Soc. Sci. Fish. 45, 67-71. Agence de santé de Wallis et Futuna, 2020. Synthèse des intoxications ciguatérique à FUTUNA depuis 2018. 2.

Aligizaki, K., Nikolaidis, G., 2008. Morphological identification of two tropical dinoflagellates of the genera Gambierdiscus and Sinophysis in the Mediterranean Sea. J. Biol. Res.-Thessalon. 9, 75-82. Anderson, D.M., Hoagland, P., Kaoru, Y., White, A.W., 2000. Estimated annual economic impacts from harmful algal blooms (HABs) in the United States. 96.

Anderson, D.M., Lobel, P.S., 1987. The continuing enigma of ciguatera. Biol. Bull. 172, 89-107.

Arena, P., Levin, B., Fleming, L.E., Friedman, M.A., Blythe, D., 2004. A pilot study of the cognitive and psychological correlates of chronic ciguatera poisoning. Harmful Algae 3, 51-60.

Australian Institute of Marine Science (AIMS), 2009. South Pacific Epidemiological And Health Information Services (SPEHIS) fish poisoning database.

Azanza, M.P., Membrebe, B.N.Q., Sanchez, R.G.R., Estilo, E.E.C., Dollete, U.G.M., Feliciano, R.J., Garcia, N.K.A., 2019. Foodborne disease outbreaks in the Philippines (2005-2018). Philipp. J. Sci. $148(2), 323-342$.

Azziz-Baumgartner, E., Luber, G., Conklin, L., Tosteson, T.R., Granade, H.R., Dickey, R.W., Backer, L.C., 2012. Assessing the incidence of ciguatera fish poisoning with two surveys conducted in Culebra, Puerto Rico, during 2005 and 2006. Environ. Health Persp. 120, 526-529.

Bagnis, R., 1980. L’ichthyosarcotoxisme dans l'Océan Indien. DGRST, IRM/K10. 154.

Bagnis, R., Julvez, J., Allaoui, A., Dubray, B., Conan, H., Ali Halidi, M.A., Mieli, L., and Galtier, J., 1988. Le risque ciguatérique dans l'île de Mayotte (Archipel des Comores). Revue Internationale d'Oceanographie Medicale. 31(3), 43-54. 
Bailey, S., Withers, T., 2014. Ciguatera poisoning in the Cook Islands. BMJ Case Rep.

Barrett, K.A., Nakao J.H.,Taylor E.V., Eggers C., Gould, L.H., 2017. Fish-Associated Foodborne Disease Outbreaks: United States, 1998-2015. Foodborne Pathogens and Disease 14(9), 537-543.

Barton, E.D., Tanner, P., Turchen, S.G., Tunget, C.L., Manoguerra, A., Clark, R.F., 1995. Ciguatera fish poisoning a Southern California epidemic. West. J. Med. 163(1), 31-35.

Baumann, F., Bourrat, M.B., Pauillac, S., 2010. Prevalence, symptoms and chronicity of ciguatera in New Caledonia: results from an adult population survey conducted in Noumea during 2005. Toxicon $56,662-667$

Beaglehole, J., 1961. Vol ii: The voyage of the resolution and adventure, 1772-1775. Cambridge University Press, Cambridge, England.

Begier, E.M., Backer, L.C., Weisman, R.S., Hammond, R.M., Fleming, L.E., Blythe, D., 2006. Outbreak bias in illness reporting and case confirmation in ciguatera fish poisoning surveillance in South Florida. Public Health Rep. 121.

Bell, J.D., Kronen, M., Vunisea, A., Nash, W.J., Keeble, G., Demmke, A., Pontifex, S., Andréfouët, S., 2009. Planning the use of fish for food security in the Pacific. Mar. Policy 33(1), 64-76.

Bentur, Y., Spanier, E., 2007. Ciguatoxin-like substances in edible fish on the Eastern Mediterranean. Clin. Toxicol. 45(6), 695-700.

Biaggi, J., 1990. Legal aspects of ciguatera fish poisoning in Puerto Rico. IIIrd International Conference on Ciguatera Fish Poisoning, 201-204.

Bienfang, P., Oben, B., DeFelice, S., Moeller, P., Huncik, K., Oben, P., Toonen, R., Daly-Engel, T., Bowen, B., 2008. Ciguatera: the detection of neurotoxins in carnivorous reef fish from the coast of Cameroon, West Africa. Afr. J. Mar. Sci. 30(3), 533-540.

Blythe, D.G., De Sylva, D.P., Cramer-Castro, S., 1992a. Ciguatera fish poisoning-the name may be difficult to remember. But if you get this disease, you'll never forget it. Aqua Int. 13, 26.

Blythe, D.G.D.S., D.P.; Fleming, L.E.; Ayyar, R.A.; Baden, D.G.; Shrank, K., 1992b. Clinical experience with I.V. Mannitol in the treatment of ciguatera. Bull. Soc. Pathol. Exot.(1990) 85, 425426. 
Boada, L.D., Zumbado, M., Luzardo, O.P., Almeida-Gonzalez, M., Plakas, S.M., Granade, H.R., Abraham, A., Jester, E.L.E., Dickey, R.W., 2010. Ciguatera fish poisoning on the West Africa Coast: an emerging risk in the Canary Islands (Spain). Toxicon 56(8), 1516-1519.

Boisier, P., Ranaivoson, G., Rasolofonirina, N., Andriamahefazafy, B., Roux, J., Chanteau, S., Satake, M., Takeshi, Y., 1995. Fatal mass poisoning in Madagascar following ingestion of a shark (Carcharhinus leucas): clinical and epidemiological aspects and isolation of toxins. Toxicon 33(10), $1359-1364$.

Boucaud-Maitre, D., Vernoux, J.-P., Pelczar, S., Daudens-Vaysse, E., Aubert, L., Boa, S., Ferracci, S., Garnier, R., 2018. Incidence and clinical characteristics of ciguatera fish poisoning in Guadeloupe (French West Indies) between 2013 and 2016: a retrospective cases-series. Scientific Reports 8(1), 3095.

Bourdy, G., Cabalion, P., Amade, P., Laurent, D., 1992. Traditional remedies used in the Western Pacific for the treatment of ciguatera poisoning. J. Ethnopharmacol. 36(2), 163-174.

Bravo, J., Suarez, F.C., Ramirez, A.S., Acosta, F., 2015. Ciguatera, an emerging human poisoning in Europe. J. Aquac. Mar. Biol. 3(1), 00053.

Bruneau, A., Mahanty, S., Al-Azraqui, T., MacLean, J., Bourque, M., Desroches, F., 1997. Ciguatera fish poisoning linked to the ingestion of barracuda in a Montreal restaurant-Quebec. Canada communicable disease report $=$ Relevé des maladies transmissibles au Canada 23(20), 153.

Brunelli, M.G.-G., M.; Mozzachiodi, R.; Roberto, M.; Scuri, R.; Traina, G.; Zaccardi, M.L., 2000. Neurotoxic effects of caulerpenyne. Prog. Neuropsychopharmacol. Biol. Psychiatry 24(6), 939-954.

Brunet, K., 2015. The follow-up of a possible risk of the ciguatera fish poisoning in Wallis and Futuna. Workshop on Ciguatera Fish Poisoning (CFP) - RAS7026 Project.

Burke, L., Maidens, J., 2005. Reefs at risk in the Caribbean. Washington: World Resources Institute, 80.

Caillaud, A., de la Iglesia, P., Darius, H.T., Pauillac, S., Aligizaki, K., Fraga, S., Chinain, M., Diogène, J., 2010. Update on methodologies available for ciguatoxin determination: perspectives to confront the onset of ciguatera fish poisoning in Europe. Mar. Drugs 8(6), 1838-1907. 
Capelle, J., Lemari, L., 2015. Marshall Islands Country Report. Workshop on Ciguatera Fish Poisoning (CFP) - RAS7026 Project.

Caplan, C.E., 1998. Ciguatera fish poisoning. CMAJ: Canadian Medical Association Journal 159(11), 1394.

Catania, D., Richlen, M.L., Mak, Y.L., Morton, S.L., Laban, E.H., Xu, Y., Anderson, D.M., Chan, L.L., Berumen, M.L., 2017. The prevalence of benthic dinoflagellates associated with ciguatera fish poisoning in the Central Red Sea. Harmful Algae 68, 206-216.

Celis, J.S., Mancera-Pineda, J.E., 2015. Análisis histórico de la incidencia de ciguatera en las Islas del Caribe durante 31 años: 1980 -2010. Bol. Invest. Mar. Cost. 44(1), 7-32.

Centers for Disease Control and Prevention (CDC), 2018. National Outbreak Reporting System (NORS). https://wwwn.cdc.gov/norsdashboard/. Last accessed 6/2/2020

Champetier de Ribes, G., Rasolofonirina, R.N., Ranaivoson, G., Razafimahefa, N., Rakotoson, J.D., Rabeson, D., 1997. Intoxication by marine animal venoms in Madagascar (ichthyosarcotoxism and chelonitoxism): recent epidemiological data. Bull. Soc. Pathol. Exot. 90(4), 286-290.

Chan, P.S.W., 2000. Current status of the live reef fish trade based in Hong Kong. SPC Live Reef Fish Information Bulletin 7, 8-9.

Chan, T.Y.K., 2013a. Ciguatera caused by consumption of humphead wrasse. Toxicon 76, 255-259. Chan, T.Y.K., 2013b. Severe bradycardia and prolonged hypotension in ciguatera. Singap. Med. J., 17.

Chan, T.Y.K., 2014a. Epidemiology and clinical features of ciguatera fish poisoning in Hong Kong. Toxins 6(10), 2989-2997.

Chan, T.Y.K., 2014b. Large outbreaks of ciguatera after consumption of brown marbled grouper. Toxins 6(7), 2041-2049.

Chan, T.Y.K., 2015a. Ciguatera fish poisoning in East Asia and Southeast Asia. Mar. Drugs 13(6), 3466-3478.

Chan, T.Y.K., 2015b. Ciguatoxic potential of brown-marbled grouper in relation to fish size and geographical origin. Am. J. Trop. Med. Hyg. 93(5), 1117-1121. 
Chan, T.Y.K., 2015c. Emergence and epidemiology of ciguatera in the coastal cities of Southern China. Mar. Drugs 13(3), 1175-1184.

Chan, T.Y.K., 2016. Characteristic features and contributory factors in fatal ciguatera fish poisoningimplications for prevention and public education. Am. J. Trop. Med. Hyg. 94(4), 704-709.

Château-Degat, M.L., Chinain, M., Darius, T., Dewailly, E., Mallet, H.P., 2009. Surveillance épidémiologique de la ciguatéra en Polynésie française. Bulletin d’Epidémiologie Hebdomadaire, BEH thématique 48-50, 522-525.

Chateau-Degat, M.L., Huin-Blondey, M.O., Chinain, M., Darius, T., Legrand, A.M., Nguyen, N.L., Laudon, F., Chansin, R., Dewailly, E., 2007. Prevalence of chronic symptoms of ciguatera disease in French Polynesian adults. Am. J. Trop. Med. Hyg. 77(5), 842-846.

Chevaldonné, P., 1990. Ciguatera and the saupe, Sarpa salpa (L.), in the Mediterranean: a possible misinterpretation. J. Fish Biol. 37, 503-504.

Chinain, M., Darius, H.T., Gatti, C.M., Roué, M., 2016. Update on ciguatera research in French Polynesia. SPC Fisheries Newsletter 150, 42-51.

Chinain, M., Darius, H.T., Ung, A., Cruchet, P., Wang, Z., Ponton, D., Laurent, D., Pauillac, S., 2010. Growth and toxin production in the ciguatera-causing dinoflagellate Gambierdiscus polynesiensis (Dinophyceae) in culture. Toxicon 56(5), 739-750.

Chinain, M., Faust, M., Pauillac, S., 1999. Morphology and molecular analyses of three toxic species of Gambierdiscus (Dinophyceae): G. pacificus, sp. nov., G. australes, sp. nov., and G. polynesiensis, sp. nov. J. Phycol. 35(6), 1282-1296.

Chinain, M., Gatti, C.M., Roué, M., Darius, H.T., 2020. Ciguatera-causing dinoflagellates in the genera Gambierdiscus and Fukuyoa: distribution, ecophysiology and toxicology, In: Durvasula, S.R. (Ed.), Dinoflagellates: Morphology, Life History and Ecological Significance. The Nova Science Publishers, Inc., New York, p. in press.

Chomérat, N., Couté, A., Quod, J.P., Turquet, J., 2008. Quelques dinophytes benthiques marins des Iles Glorieuses (sud ouest de l'Océan Indien). Cryptogamie Algol. 29(4), 356. 
Clua, E., Brena, P.F., Lecasble, C., Ghnassia, R., Chauvet, C., 2011. Prevalence and proposal for costeffective management of the ciguatera risk in the Noumea fish market, New Caledonia (South Pacific). Toxicon 58(6-7), 591-601.

Darius, H.T., Roué, M., Sibat, M., Viallon, J., Gatti, C.M., Vandersea, M.W., Tester, P.A., Litaker, R.W., Amzil, Z., Hess, P., Chinain, M., 2018a. Tectus niloticus (Tegulidae, Gastropod) as a novel vector of ciguatera poisoning: detection of pacific ciguatoxins in toxic samples from Nuku Hiva Island (French Polynesia). Toxins 10(1), 2.

Darius, H.T., Roué, M., Sibat, M., Viallon, J., Gatti, C.M., Vandersea, M.W., Tester, P.A., Litaker, R.W., Amzil, Z., Hess, P., Chinain, M., 2018b. Toxicological investigations on the sea urchin Tripneustes gratilla (Toxopneustidae, Echinoid) from Anaho Bay (Nuku Hiva, French Polynesia): evidence for the presence of pacific ciguatoxins. Mar. Drugs 16(4), 122.

de Haro, L., Hayek-Lanthois, M., Joosen, F., Pes, P., Castanier, L., Jouglard, J., 1997. Medical management in the Marseilles Poison Centre of a ciguatera poisoning collective case after a meal of one barracuda in Mexico. Toxicon 35(6), 810.

de Haro, L., Pommier, P., 2006. Hallucinatory fish poisoning (ichthyoallyeinotoxism): two case reports from the Western Mediterranean and literature review. Clin. Toxicol. 44(2), 185-188.

de Haro, L., Pommier, P., Valli, M., 2003. Emergence of imported ciguatera in Europe: report of 18 cases at the Poison Control Centre of Marseille. J. Toxicol. Clin. Toxicol. 41(7), 927-930.

de Haro, L., Schmitt, C., Glaizal, M., Domangé, B., Torrents, R., Simon, N., 2020. La ciguatera: 25 ans d'expérience du Centre Antipoison de Marseille. Toxicologie Analytique et Clinique 32(1), 23 32.

Dembert, M., Pearn, J., 1982. Physicians: know thy ciguatera poisoning symptoms! Am. J. Public Health 72(11), 1298-1298.

Díaz-Asencio, L., Clausing, R.J., Vandersea, M., Chamero-Lago, D., Gómez-Batista, M., HernándezAlbernas, J.I., Chomérat, N., Rojas-Abrahantes, G., Litaker, R.W., Tester, P., Diogène, J., AlonsoHernández, C.M., Dechraoui Bottein, M.-Y., 2019a. Ciguatoxin occurrence in food-web components of a Cuban coral reef ecosystem: risk-assessment implications. Toxins 11(12), 722. 
Díaz-Asencio, L., Vandersea, M., Chomérat, N., Fraga, S., Clausing, R., Litaker, R., Chamero-Lago, D., Gómez-Batista, M., Moreira-González, A., Tester, P., Alonso-Hernández, C., Dechraoui Bottein, M., 2019b. Morphology, toxicity and molecular characterization of Gambierdiscus spp. towards risk assessment of ciguatera in South Central Cuba. Harmful Algae 86, 119-127.

Dickey, R.W., Plakas, S.M., 2010. Ciguatera: a public health perspective. Toxicon 56(2), 123-136.

Diogène, J., Reverté, L., Rambla-Alegre, M., del Rio, V., de la Iglesia, P., Campas, M., Palacios, O., Flores, C., Caixach, J., Ralijaona, C., Razanajatovo, I., Pirog, A., Magalon, H., Arnich, N., Turquet, J., 2017. Identification of ciguatoxins in a shark involved in a fatal food poisoning in the Indian Ocean. Sci. Rep. 7(1), 8240.

Disease Outbreak Control Division- State of Hawaii, 2019. Historical data of reported cases of notifiable diseases for state of Hawaii, Honolulu County, Hawaii County, Kauai County, and Maui County (1990-2018).

Doherty, M.D., 2005. Captain Cook on poison fish. Neurology 65, 1788-1791.

Doorenbos, N., 1984. Ciguatera toxins: where do we go from here? American Chemical Society, Washington D.C., pp. 60-73.

Edwards, A., Zammit, A., Farrell, H., 2019. Four recent ciguatera fish poisoning incidents in New South Wales, Australia linked to imported fish. Commun. Dis. Intell. 43, 1-9.

El Masry, M., Tawfik, H., 2013. 2011 Annual report of the poison control centre of Ain Shams University Hospital, Cairo, Egypt. Ain Shams J. Forensic Med. Clin. Toxicol. 20(1), 10-17.

El Masry, M.K., Fawzi, M.M., 2011. Tetrodotoxin versus ciguatera fish poisoning in the Mediterranean Sea. Ind. J. Forensic Med. Toxicol. 5(2), 50-53.

Epelboin, L., Pérignon, A., Hossen, V., Vincent, R., Krys, S., Caumes, E., 2014. Two clusters of ciguatera fish poisoning in Paris, France, related to tropical fish imported from the French Caribbean by travelers. J. Travel Med. 21(6), 397-402.

European Food Safety Authority (EFSA), 2010. Scientific opinion on marine biotoxins in shellfish Emerging toxins: ciguatoxin group. EFSA Journal 8(6), 1627.

Farrell, H., Murray, S.A., Zammit, A., Edwards, A.W., 2017. Management of ciguatoxin risk in Eastern Australia. Toxins 9(11), 367. 
Farstad, D.J., Chow, T., 2001. A brief case report and review of ciguatera poisoning. Wild. Environ. Med. 12(4), 263-269.

Faust, M.A., 1995. Observation of sand-dwelling toxic dinoflagellates (Dinophyceae) from widely differing sites, including two new species. J. Phycol. 31(6), 996-1003.

Fleming, L., Baden, D., Bean, J., Weisman, R., Blythe, D., 1998. Seafood toxin diseases: issues in epidemiology \& community outreach, In: Reguera, B., lanco, J., Fernandez, M.L., Wyatt, T. (Eds.), Harmful Algae. Xunta de Galicia and Intergovernmental Oceanographic Commission of UNESCO, pp. 245-248.

Fleming, L.E.B., D., 1997. Ciguatera fish poisoning. Shoreman's Travel Med. Mon. 1, 1-5.

Food and Agricultural Organization of the United Nations (FAO), 2016. Codex Alimentarius. http://www.fao.org/fao-who-codexalimentarius/news-and-events/news-details/en/c/1173604/. Last accessed 6/2/2020

Food and Agricultural Organization of the United Nations (FAO), 2020. The State of World Fisheries and Aquaculture 2020. Sustainability in action. 244.

Food and Agricultural Organization of the United Nations (FAO) and World Health Organization (WHO), 2020. Expert Meeting on Ciguatera Poisoning. 9(574).

Food and Drug Administration, U.F., 2013. Guidance for Industry Purchasing Reef Fish Species Associated with the Hazard of Ciguatera Fish Poisoning.

Fraga, S., Rodríguez, F., 2014. Genus Gambierdiscus in the Canary Islands (NE Atlantic Ocean) with description of Gambierdiscus silvae sp. nov., a new potentially toxic epiphytic benthic dinoflagellate. Protist 165(6), 839-853.

Fraga, S., Rodríguez, F., Caillaud, A., Diogène, J., Raho, N., Zapata, M., 2011. Gambierdiscus excentricus sp. nov. (Dinophyceae), a benthic toxic dinoflagellate from the Canary Islands (NE Atlantic Ocean). Harmful Algae 11, 10-22.

Fraga, S., Rodríguez, F., Riobó, P., Bravo, I., 2016. Gambierdiscus balechii sp. nov (Dinophyceae), a new benthic toxic dinoflagellate from the Celebes Sea (SW Pacific Ocean). Harmful Algae 58, 93 105. 
Freudenthal, A.R., 1990. Public health aspects of ciguatera poisoning contracted on tropical vacations by North American tourists, Toxic Marine Phytoplankton. Elsevier, New York, pp. 463-468.

Friedemann, M., 2019. Ciguatera fish poisoning outbreaks from 2012 to 2017 in Germany caused by snappers from India, Indonesia, and Vietnam. J. Consum. Prot. Food Saf. 14(1), 71-80.

Friedman, M.A., Fernandez, M., Backer, L.C., Dickey, R.W., Bernstein, J., Schrank, K., Kibler, S., Stephan, W., Gribble, M.O., Bienfang, P., Bowen, R.E., Degrasse, S., Flores Quintana, H.A., Loeffler, C.R., Weisman, R., Blythe, D., Berdalet, E., Ayvar, R., Clarkson-Townsend , D., Swajian , K., Benner, $\begin{array}{lllll}\text { R., } & \text { Brewer, } & \text { T., } & \text { Fleming, } & \text { L.E., }\end{array}$ An updated review of ciguatera fish poisoning: clinical, epidemiological, environmental, and public health management. Mar. Drugs 15(3), 72.

Friedman, M.A., Fleming, L.E., Fernandez, M., Bienfang, P., Schrank, K., Dickey, R., Bottein, M.Y., Backer, L., Ayyar, R., Weisman, R., Watkins, S., Granade, R., Reich, A., 2008. Ciguatera fish poisoning: treatment, prevention and management. Mar. Drugs 6(3), 456-479.

Fukuyo, Y., 2018. CFP study and management - The experience of Japan. WESTPAC Training Workshop on "Applying analytical method for detecting ciguatoxins (CTXs) in fish".

Gatti, C.M., Lonati, D., Darius, H.T., Zancan, A., Roué, M., Schicchi, A., Locatelli, C.A., Chinain, M., 2018. Tectus niloticus (Tegulidae, Gastropod) as a novel vector of ciguatera poisoning: clinical characterization and follow-up of a mass poisoning event in Nuku Hiva Island (French Polynesia). Toxins 10(3), 102.

Gatti, C.M., Oelher, E., Legrand, A.M., 2008. Severe seafood poisoning in French Polynesia: a retrospective analysis of 129 medical files. Toxicon 51(5), 746-753.

GCS, 2004. Os Serviços de Saúde registaram o primeiro caso suspeito anual de envenenamento por ciguatera provocado pela ingestão de peixe no exterior.

GCS, 2005. Primeiro caso suspeito de envenenamento por ciguatera, registado este ano pelos Serviços de Saúde, provocado pela ingestão de peixe.

GCS, 2006. Caso suspeito de envenenamento por ciguatera, informado aos Serviços de Saúde, provocado pela ingestão de peixe. 
Gingold, D.B., Strickland, M.J., Hess, J.J., 2014. Ciguatera fish poisoning and climate change: analysis of national poison center data in the United States, 2001-2011. Environ. Health Persp. 122(6), 580586.

Glaziou, P., Legrand, A.M., 1994. The epidemiology of ciguatera fish poisoning. Toxicon 32(8), 863873.

Goater, S., Derne, B., Weinstein, P., 2011. Critical issues in the development of health information systems in supporting environmental health: a case study of ciguatera. Environ. Health Persp. 119, $585-590$

Goldenberg, S.B., Landsea, C.W., Mestas-Nunez, M., Gray, W.M., 2001. The recent increase in Atlantic hurricane activity: Causes and implications. Science 239, 474-479.

Gouveia, N., Delgado, J., Gouveia, N., Vale, P., 2009. Primeiro registo da ocorrência de episódios do tipo ciguatérico no arquipélago da Madeira, In: Costa, P.R., Botelho, M.J., Rodrigues, S.M., Palma, A.S., Moita, M.T. (Eds.), Algas tóxicas e biotoxinas nas águas da Península Ibérica. IPIMAR, Lisboa, Potugal, pp. 152-157.

Grzebyk, D., Berland, B., Thomassin, B.A., Bosi, C., Arnoux, A., 1994. Ecology of ciguateric dinoflagellates in the coral reef complex of Mayotte Island (S.W. Indian Ocean). J. Exp. Mar. Biol. Ecol. 178(1), 51-66.

Ha, D.V., Uesugi, A., Uchida, H., Ky, P.X., Minh, D.Q., Watanabe, R., Matsushima, R., Oikawa, H., Nagai, S., Iwataki, M., Fukuyo, Y., Suzuki, T., 2018. Identification of causative ciguatoxins in red snappers Lutjanus bohar implicated in ciguatera fish poisonings in Vietnam. Toxins 10(10), 420.

Habermehl, G.G., Krebs, H.C., Rasoanaivo, P., Ramialiharisoa, A., 1994. Severe ciguatera poisoning in Madagascar: a case report. Toxicon 32(12), 1539-1542.

Hales, S., Weinstein, P., Woodward, A., 1999. Ciguatera (fish poisoning), El Niño, and Pacific sea surface temperatures. Ecosyst. Health 5(1), 20-25.

Halstead, B.W., 1967. Poisonous and venomous marine animals of the world., ed. US Government Printing Office, Washington, DC, USA.

Halstead, B.W., 1978. Poisonous and venomous marine animals of the world. Darwin Press, Princeton, New Jersey. 
Halstead, B.W., Cox, K.W., 1973. An investigation on fish poisoning in Mauritius. Imprimerie Commerciale.

Hamilton, B., Hurbungs, M., Jones, A., Lewis, R.J., 2002a. Multiple ciguatoxins present in Indian Ocean reef fish. Toxicon 40(9), 1347-1353.

Hamilton, B., Hurbungs, M., Vernoux, J.P., Jones, A., Lewis, R.J., 2002b. Isolation and characterisation of Indian Ocean ciguatoxin. Toxicon 40(6), 685-693.

Hansen, G., Turquet, J., Quod, J.P., Ten-Hage, L., Lugomela, C., Kyewalyanga, M., Hurbungs, M., Wawiye, P., Ogongo, B., Tunje, S., Rakotoarinjanahary, H., 2001. Potentially harmful micoralgae of the Western Indian Ocean - a guide based on a preliminary survey. IOC Manuals and Guides 41.

Hardison, D.R., Holland, W.C., McCall, J.R., Bourdelais, A.J., Baden, D.G., Darius, H.T., Chinain, M., Tester, P.A., Shea, D., Flores Quintana, H.A., Morris, J.A., Jr., Litaker, R.W., 2016. Fluorescent Receptor Binding Assay for detecting ciguatoxins in fish. PLOS One 11(4), e0153348.

Ho, T.V., Bing, H.Y.N., 2018. First report of Gambierdiscus caribaeus and G. carpenteri (Dinophyceae) from Nha Trang Bay, South Central Vietnam. J. Mar. Biol. Ass. India 60(2), 5-11.

Hossen, V., Soliño, L., Leroy, P., David, E., Velge, P., Dragacci, S., Krys, S., Flores Quintana, H., Diogène, J., 2015. Contribution to the risk characterization of ciguatoxins: LOAEL estimated from eight ciguatera fish poisoning events in Guadeloupe (French West Indies). Environ. Res. 143, 100108.

IAMAT, 2017. Ciguatera fish poisoning. https://www.iamat.org/risks/ciguatera-fish-poisoning. Last accessed 27/11/2019

IDSEP, 2000. Weekly Epidemiological Bulletin - Week 37.

Institut Louis Malardé (ILM), 2007-2018. Ciguatera Epidemiology Annual Report.

Intergovernmental Panel on Climate Change (IPCC), 2007. Climate change 2007 - the physical science basis: contribution of working group I to the Fourth Assessment Report of the IPCC. 996. Iorangi, T., Nanai, A., 2017. National Health Information Bulletin 2016. 71.

Jang, S.H., Jeong, H.J., Yoo, Y.D., 2018. Gambierdiscus jejuensis sp. nov., an epiphytic dinoflagellate from the waters of Jeju Island, Korea, effect of temperature on the growth, and its global distribution. Harmful Algae 80, 149-157. 
Jeong, H.J., Lim, A.S., Jang, S.H., Yih, W.H., Kang, N.S., Lee, S.Y., Yoo, Y.D., Kim, H.S., 2012. First report of the epiphytic dinoflagellate Gambierdiscus caribaeus in the temperate waters off Jeju Island, Korea: morphology and molecular characterization. J. Eukaryot. Microbiol. 59(6), 637-650. Johannes, R.E., Riepen, M., 1995. Environmental, economic, and social implications of the live reef fish trade in Asia and the Western Pacific. 82, http://agris.fao.org/agrissearch/search.do?recordID=XF2015023335.

Jones, J.D., 1956. Observations on fish poisoning in Mauritius. Proc. R. Soc. Arts Sci. Mauritius 1(4), 367-385.

Karunasagar, I., Turner, A.D., Maskrey, B., Robertson, A., Shivanagouda Hosagoudar, S., Rai, P., Adappa, S., Hiremath, S., Kogaluru Shivakumaraswamy, S., Dechraoui Bottein, M.Y., Clausing, R., Turner, L., Godhe, A., 2018. Report of a major outbreak of ciguatera fish poisoning in Mangalore, India. 18th International Conference on Harmful Algae, 482.

Katz, A.R., Terrell-Perica, S., Sasaki, D.M., 1993. Ciguatera on Kauai: investigation of factors associated with severity of illness. Am. J. Trop. Med. Hyg. 49(4), 448-454.

Kibler, S.R., Tester, P.A., Kunlec, K.E., Moored, S.K., Litaker, W.R., 2015. Effects of ocean warming on growth and distribution of dinoflagellates associated with ciguatera fish poisoning in the Caribbean. Ecol. Model. 316, 194-210.

Kintzing, M.D., Butler, I.M., 2014. Effects of predation upon the long-spined sea urchin Diadema antillarum by the spotted spiny lobster Panulirus guttatus. Marine Ecology Progress Series 495, $185-$ 191.

Kiteresi, L., Ochieng, O.E., Mwangi, S., Mkonu, M., 2013. Potentially harmful algae along the Kenyan coast: a norm or threat. Journal of Environment and Earth Science 3(9), 1-10.

Kretzschmar, A.L., Larsson, M.E., Hoppenrath, M., Doblin, M.A., Murray, S.A., 2019. Characterisation of two toxic Gambierdiscus spp. (Gonyaulacales, Dinophyceae) from the Great Barrier Reef (Australia): G. lewisii sp. nov. and G. holmesii sp. nov. Protist 170(6), 125699.

Kretzschmar, A.L., Verma, A., Harwood, D.T., Hoppenrath, M., Murray, S., 2017. Characterization of Gambierdiscus lapillus sp. nov. (Gonyaulacales, Dinophyceae): a new toxic dinoflagellate from the Great Barrier Reef (Australia). J. Phycol. 53(2), 283-297. 
Kumar-Roiné, S., Darius, H.T., Matsui, M., Fabre, N., Haddad, M., Chinain, M., Pauillac, S., Laurent, D., 2011. A review of traditional remedies of ciguatera fish poisoning in the Pacific. Phytother. Res. 25(7), 947-958.

Lagraulet, J., 1975a. Ciguatera in the Maldive Islands. Bull. Soc. Pathol. Exot. Filiales 68(5), 511-515. Lagraulet, J., 1975b. A propos de l'ichthyotoxisme aux Iles Seychelles. Bull. Soc. Pathol. Exot. Filiales $68(1), 115-122$.

Lange, W.R., 1987. Ciguatera toxicity. Am. Fam. Physician 35(4), 177-182.

Lange, W.R., Snyder, F.R., Fudala, P.J., 1992. Travel and ciguatera fish poisoning. Arch. Intern. Med. 152(10), 2049-2053.

Larsson, M.E., Harwood, T.D., Lewis, R.J., Himaya, S.W.A., Doblin, M.A., 2019. Toxicological characterization of Fukuyoa paulensis (Dinophyceae) from temperate Australia. Phycol. Res. 67(1), $65-71$

Larsson, M.E., Laczka, O.F., Harwood, D.T., Lewis, R.J., Himaya, S.W.A., Murray, S.A., Doblin, M.A., 2018. Toxicology of Gambierdiscus spp. (Dinophyceae) from tropical and temperate Australian waters. Mar. Drugs 16(1), 7.

Laurent, D., Kerbrat, A.-S., Darius, H.T., Girard, E., Golubic, S., Benoit, E., Sauviat, M.-P., Chinain, M., Molgo, J., Pauillac, S., 2008. Are cyanobacteria involved in Ciguatera Fish Poisoning-like outbreaks in New Caledonia? Harmful Algae 7(6), 827-838.

Laurent, D., Kerbrat, A.S., Darius, H.T., Rossi, F., Yeeting, B., Haddad, M., Golubic, S., Pauillac, S., Chinain, M., 2012. Ciguatera shellfish poisoning (CSP): a new ecotoxicological phenomenon from cyanobacteria to humans via giant clams., In: Jensen, M.A., et al, (Ed.), Food Chains: New Research. Nova Science Publishers, Inc., NewYork, pp. 1-43.

Lavenu, L., Chomérat, N., Díaz-Asencio, L., Gerry, C., Belmont, C., Hollanda, S., Tunin-Ley, A., Dechraoui Bottein, M.Y., 2018. Gambierdiscus from Seychelles: morphology, molecular identification and toxicity. 18th International Conference on Harmful Algae, 497.

Lawrence, D.N.E., M.B.; Lumish, R.M.; Maceo, A. , 1980. Ciguatera fish poisoning in Miami. J. Am. Med. Assoc. 244, 254-258. 
Le Bouquin, V., d'Hooge, G., Quod, J.P., Marasse, C., 1993. Ciguatera une forme particulière à la Réunion. La Presse Médicale 22, 1061.

Lebeau, A., 1979. La ciguatera dans l'Océan Indien: étude des poissons vénéneux des bancs de l'archipel des Mascareignes et de la crête centrale de l'Océan Indien. Re. Trav. Inst. Pêches Maritimes $42(4), 325-345$.

Lee, H.G., Leaw, C.P., Jipanin, S.J., 2019. Ciguatera fish poisoning: first reported case in Sabah, Malaysia. Med J Malaysia 74(6), 545.

Lehane, L., Lewis, R.J., 2000. Ciguatera: recent advances but the risk remains. Int. J. Food Microbiol. 61(2-3), 91-125.

Lewis, N.D., 1986. Epidemiology and impact of ciguatera in the Pacific: a review. Marine Fisheries Review 48(4), 6-13.

Lewis, R.J., 2001. The changing face of ciguatera. Toxicon 39(1), 97-106.

Lewis, R.J., Sellin, M., 1992. Multiple ciguatoxins in the flesh of fish. Toxicon 30(8), 915-919.

Lim, Z.F., 2018. Status of ciguatera in Malaysia 2018. WESTPAC Training Workshop on "Applying analytical method for detecting Ciguatoxins (CTXs) in fish".

Lin, W.-F., Hwang, D.-F., 2012. Analysis of poisoning cases, monitoring and risk warning for marine toxins (TTX, PSP and CTXs) in Taiwan. Journal of Food and Drug Analysis 20(4), 764-771.

Litaker, R.W., Hardison, R.D., Holland, W.C., Bourdelais, A.J., Mc Call, J.R., Baden, D.G., Morris, J.A., Jr, Bogdanoff, A.K., Tester, P.A., 2014. Ciguatoxin concentrations in invasive lionfish estimated using a fluorescent receptor binding assay. Proceedings of the 16th International Conference on Harmful Algae, Wellington, New Zealand, 184-187.

Litaker, R.W., Holland, W.C., Hardison, D.R., Pisapia, F., Hess, P., Kibler, S.R., 2017. Ciguatoxicity of Gambierdiscus and Fukuyoa species from the Caribbean and Gulf of Mexico. PLoS One 12(10), e0185776.

Litaker, R.W., Tester, P.A., Vandersea, M.W., 2019. Species-specific PCR assays for Gambierdiscus excentricus and Gambierdiscus silvae (Gonyaulacales, Dinophyceae). J. Phycol. 55(3), 730-732.

Litaker, R.W., Vandersea, M.W., Faust, M.A., Kibler, S.R., Chinain, M., Holmes, M.J., Holland, W.C., Tester, P.A., 2009. Taxonomy of Gambierdiscus including four new species, Gambierdiscus 
caribaeus, Gambierdiscus carolinianus, Gambierdiscus carpenteri and Gambierdiscus ruetzleri (Gonyaulacales, Dinophyceae). Phycologia 48(5), 344-390.

Litaker, R.W., Vandersea, M.W., Faust, M.A., Kibler, S.R., Nau, A.W., Holland, W.C., Chinain, M., Holmes, M.J., Tester, P.A., 2010. Global distribution of ciguatera causing dinoflagellates in the genus Gambierdiscus. Toxicon 56(5), 711-730.

Longo, S., Sibat, M., Viallon, J., Darius, T.H., Hess, P., Chinain, M., 2019. Intraspecific variability in the toxin production and toxin profiles of in vitro cultures of Gambierdiscus polynesiensis (Dinophyceae) from French Polynesia. Toxins 11, 735.

López, R.M.G., 1999. Felipe Poey y Aloy: Obras. Imagen Contemporánea, La Habana, Cuba.

Lugomela, C., 2006. Autecology of the toxic dinoflagellate Gambierdiscus toxicus Adachi et Fukuyo (Dinophyceae) in central coastal areas of Tanzania. Western Indian Ocean J. Mar. Sci. 5(2), 213-221. Mak, Y.L., Wai, T.-C., Murphy, M.B., Chan, W.H., Wu, J.J., Lam, J.C.W., Chan, L.L., Lam, P.K.S., 2013. Pacific ciguatoxins in food web components of coral reef systems in the Republic of Kiribati. Environ. Sci. Technol. 47, 14070-14079.

Matta, J., Navas, J., Milad, M., Manger, R., Hupka, A., Frazer, T., 2002. A pilot study for the detection of acute ciguatera intoxication in human blood. J. Toxicol. Clin. Toxicol. 40(1), 49-57.

Mattei, C., Vetter, I., Eisenblatter, A., Krock, B., Ebbecke, M., Desel, H., Zimmermann, K., 2014. Ciguatera fish poisoning: a first epidemic in Germany highlights an increasing risk for European Countries. Toxicon, 1-8.

McKee, D.B., Fleming, L.E., Tamer, R., Weisman, R., Blythe, D., 2001. Physician diagnosis and reporting of ciguatera fish poisoning in an endemic area. Harmful Algal Blooms, 451-453.

Mendoza, C.O., Rabanes, A.C., Jimenez, E.C., Azanza, R.V., Cortez-Akhunzadah, J., Cruz, L.J., 2013. Detection of fish poisoning in the Philippines. J. Environ. Sci. Manag. 16(special issue 1), 50-55.

Meyer, L., Capper, A., Carter, S., Simpfendorfer, C., 2016. An investigation into ciguatoxin bioaccumulation in sharks. Toxicon 119, 234-243.

Morin, E., Gatti, C., Bambridge, T., Chinain, M., 2016. Ciguatera fish poisoning: incidence, health costs and risk perception on Moorea Island (Society Archipelago, French Polynesia). Harmful Algae $60,1-10$. 
Morris, J.G., Lewis, P., Hargrett, N.T., Smith, W., Blake, P.A., Schneider, R., 1982. Clinical features of ciguatera fish poisoning: a study of the disease in the US Virgin Islands. Arch. Intern. Med. 141, 1090-1092.

Morris, J.G.J., 1990. Ciguatera fish poisoning: barracuda's revenge. South. Med. J. 83(4), 371-372.

Morris, P.D., Campbell, D.S., Freeman, J.I., 1990. Ciguatera fish poisoning: an outbreak associated with fish caught from North Carolina coastal waters. South. Med. J. 83(4), 379-382.

Muecke, C., Hamper, L., Skinner, A.L., Osborne, C., 2015. Ciguatera fish poisoning in an international ship crew in Saint John Canada. CCDR 41(11).

Munir, S., Siddiqui, P.J.A., Morton, S.L., 2011. The occurrence of the ciguatera fish poisoning producing dinoflagellate genus Gambierdiscus in Pakistan Waters. Algae 26(4), 317-325.

Nagai, H., Murata, M., Torigoe, K., Satake, M., Yasumoto, T., 1992. Gambieric acids, new potent antifungal substances with unprecedented polyether structures from a marine dinoflagellate Gambierdiscus toxicus. The Journal of Organic Chemistry 57(20), 5448-5453.

Nascimento, S.M., Melo, G., Salgueiro, F., Dos Santos Diniz, B., Fraga, S., 2015. Morphology of Gambierdiscus excentricus (Dinophyceae) with emphasis on sulcal plates. Phycologia 54(6), 628-639. National Marine Fisheries Service (NMFS) Washington, D.C., 2008. Fisheries statistics of the Unitied States - 2007. Current Fisheries Statistics No. 2007118.

Nellis, D.W., Barnard, G.W., 1986. Ciguatera: a legal and social overview. Marine Fisheries Review. Nishimura, T., Hariganeya, N., Tawong , W., Sakanari, H., Yamaguchi , H., Adachi, M., 2016. Quantitative PCR assay for detection and enumeration of ciguatera-causing dinoflagellate Gambierdiscus spp. (Gonyaulacales) in coastal areas of Japan. Harmful Algae 52, 11-22.

Nordström, S., 2013. Ciguatera fish poisoning. Biology Education Centre, Uppsala University, and Livsmedelsverket Master of Science.

Núñez-Vázquez, E.J., Almazán-Becerril, A., López-Cortés, D.J., Heredia-Tapia, A., HernándezSandoval, F.E., Band-Schmidt, C.J., Bustillos-Guzmán, J.J., Gárate-Lizárraga, I., García-Mendoza, E., Salinas-Zavala, C.A., Cordero-Tapia, A., 2019. Ciguatera in Mexico (1984-2013). Mar. Drugs 17(1), 13. 
Nuñez, D., Matute, P., Garcia, A., Garcia, P., Abadía, N., 2012. Outbreak of ciguatera food poisoning by consumption of amberjack (Seriola spp.) in the Canary Islands, may 2012. Euro Surveillance 17(23), 20188.

Oshiro, N., Yogi, K., Asato, S., Sasaki, T., Tamanaha, K., Hirama, M., Yasumoto, T., Inafuku, Y., 2010. Ciguatera incidence and fish toxicity in Okinawa, Japan. Toxicon 56, 656-661.

Otero, P., Pérez, S., Alfonso, A., Vale, C., Rodriguez, P., Gouveia, N.N., Gouveia, N., Delgado, J., Vale, P., Hirama, M., Ishihara, Y., Molgo, J., Botana, L.M., 2010. First toxin profile of ciguateric fish in Madeira Arquipelago (Europe). Anal. Chem. 82(14), 6032-6039.

Parsons, M.L., Richlen, M.L., 2016. An overview of ciguatera fish poisoning in the Bahamas. The 15th Symposium on the Natural History of the Bahamas, 1-10.

Parsons, M.L., Settlemier, C.J., Bienfang, P.K., 2010. A simple model capable of simulating the population dynamics of Gambierdiscus, the benthic dinoflagellate responsible for ciguatera fish poisoning. Harmful Algae 10(1), 71-80.

Paul, V.J., Fenical, W., 1986. Chemical defense in tropical green algae, order caulerpales. Marine Ecology Progress Series 34, 157-169.

Pawlowiez, R., Darius, H.T., Cruchet, P., Rossi, F., Caillaud, A., Laurent, D., Chinain, M., 2013. Evaluation of seafood toxicity in the Australes Archipelago (French Polynesia) using the neuroblastoma cell-based assay. Food Addit. Contam. A 30(3), 567-586.

Pearn, J., 2001. Neurology of ciguatera. J. Neurol. Neurosurg. Ps. 70(1), 4-8.

Pearn, J.H., 1996. Chronic ciguatera : one organic cause of the chronic fatigue syndrome. Journal of Chronic Fatigue Syndrome 2(3), 29-34.

Pennotti, R., Scallan, E., Backer, L., Thomas, J., Angulo, F.J, 2013. Ciguatera and Scombroid Fish Poisoning in the United States. Foodborne Pathogens and Disease 10(12), 1059-1066.

Pérez-Arellano, J.L., Luzardo, O.P., Perez Brito, A., Hernandez Cabrera, M., Zumbado, M., Carranza, C., Angel-Moreno, A., Dickey, R.W., Boada, L.D., 2005. Ciguatera fish poisoning, Canary Islands. Emerg. Infect. Dis. 11(12), 1981-1982. 
Pisapia, F., Holland, W.C., Hardison, D.R., Litaker, R.W., Fraga, S., Nishimura, T., Adachi, M., Nguyen-Ngoc, L., Séchet, V., Amzil, Z., Herrenknecht, C., Hess, P., 2017a. Toxicity screening of 13 Gambierdiscus strains using neuro-2a and erythrocyte lysis bioassays. Harmful Algae 63, 173-183. Pisapia, F., Sibat, M., Herrenknecht, C., Lhaute, K., Gaiani, G., Ferron, P.-J., Fessard, V., Fraga , S., Nascimento, S.M., Litaker, R.W., Holland, W.C., Roullier, C., Hess, P., 2017b. Maitotoxin-4, a novel MTX analog produced by Gambierdiscus excentricus. Mar. Drugs 15(7), 220.

Putra, D.F., 2018. Current situation of CFP - Indonesia. WESTPAC Training Workshop on "Applying analytical method for detecting ciguatoxins (CTXs) in fish".

Quod, J.-P., Chomérat, N., Bilien, G., Durville, P., 2020. Are mesophotic seamounts reservoirs for potentially toxic dinoflagellates associated with Ciguatera poisoning? A case study from the SW Indian ocean (expédition La Pérouse, 2019). Harmful Algae News 64, 13.

Quod, J., 2014. Risque ciguatérique dans les îles de Wallis \& Futuna, évaluation et mise en place d'un plan de surveillance., 42 .

Quod, J.P., 1994. Ostreopsis mascarenensis sp. nov. (Dinophyceae), dinoflagellé toxique associé à la ciguatera dans l'Océan Indien. Crytpogamie Algol. 15, 243-251.

Quod, J.P., Prunaux, O., Guignard, A., 1990. Les empoisonnements par poissons tropicaux à la Réunion: synthèse et perspectives. Rev. Méd. Vét. 141, 1005-1009.

Quod, J.P., Turquet, J., 1996. Ciguatera in Reunion Island (SW Indian Ocean): epidemiology and clinical patterns. Toxicon 34(7), 779-785.

Quod, J.P., Turquet, J., Conejero, S., Ralijaona, C., 2000. Ciguatera risk assessment in the Indian Ocean following the 1998 coral bleaching event, In: Souter, D., Obura, D., Lindén, O. (Eds.), Coral reef degradation in the Indian Ocean. CORDIO SAREC Marine Science Stockholm, pp. 166-168. Radke, E.G., Grattan, L.M., Cook, R.L., Smith, T.B., Anderson, D.M., Morris, J.G.J., 2013. Ciguatera incidence in the US Virgin Islands has not increased over 30-year time period despite rising seawater temperatures. Am. J. Trop. Med. Hyg. 88(5), 908-913.

Radke, E.G., Reich, A., Morris, J.G., 2015. Epidemiology of ciguatera in Florida. Am. J. Trop. Med. Hyg. 93(2), 425-432. 
Raikhlin-Eisenkraft, B., Bentur, Y., 2002. Rabbitfish (" aras »): an unusual source of ciguatera poisoning. Isr. Med. Assoc. J. 4(1), 28-30.

Rains, L.K., Parsons, M.L., 2015. Gambierdiscus species exhibit different epiphytic behaviors toward a variety of macroalgal hosts. Harmful Algae 49, 29-39.

Rajeish, M., Shekar, M., Madhushree, H., Venugopal, M., 2016. Presumptive case of ciguatera fish poisoning in Mangalore, India. Curr. Sci. 111(9), 1543-1547.

Rajisha, R., Kishore, P., Panda, S.K., Harikrisnan, G., Ajitha, K.C., Suresh, M.K., Chowdhury, L.M., Ravishankar, C.N., Kumar, K.A., 2017a. Incidence of ciguatoxin fish poisoning in Trivandrum, India. Indian J. Fish. 64(4), 129-133.

Rajisha, R., Kishore, P., Panda, S.K., Ravishankar, C.N., Kumar, K.A., 2017b. Confirmation of ciguatoxin fish poisoning in red snapper, Lutjanus bohar (Forsskål, 1775) by mouse bioassay. Fishery Technology 54, 287-290.

Randall, J.E., 1958. A review of ciguatera, tropical fish poisoning, with a tentative explanation of its cause. B. Mar. Sci. 8(3), 236-267.

Razzaghi, H., Martin, D.N., Quesnel-Crooks, S., Hong, Y., Gregg, E., Andall-Brereton, G., Gawryszweski, V., Saraiya, M., 2019. 10-year trends in noncommunicable disease mortality in the Caribbean Region. Rev. Panam. Salud Publica 43, e37.

Rebato, N., de Los Reyes, V.C., Sucaldito, M.N., Gallardo, F.D.L., Ballera, J.E., Asuncion, I., Hartigan-Go, K., 2018. Consumption of barracuda in the Caribbean Sea linked to ciguatera fish poisoning among Filipino seafarers. Western Pacific surveillance and response journal : WPSAR 9(4), $12-15$.

Reverté, L., Toldrà, A., Andree, K.B., Fraga, S., Falco, G., Campàs, M., Diogène, J., 2018. Assessment of cytotoxicity in ten strains of Gambierdiscus australes from Macaronesian Islands by neuro-2a cellbased assays. J. Appl. Phycol. 30(4), 2447-2461.

Rhodes, L., Smith, K., 2018. A checklist of the benthic and epiphytic marine dinoflagellates of New Zealand, including Rangitāhua/Kermadec Islands. New Zeal. J. Mar. Fresh. 53(2), 1-20.

Rhodes, L.L., Smith, K., Harwood, T., Selwood, A., Argyle, P., Bedford, C., Munday, R., 2014. Gambierdiscus and Ostreopsis from New Zealand, the Kermadec Islands and the Cook Islands and the 
risk of ciguatera fish poisoning in New Zealand. Proceedings of the 16th International Conference on Harmful Algae, Wellington, New Zeland, 27-31.

Rhodes, L.L., Smith, K.F., Murray, J.S., Nishimura, T., Finch, S.C., 2020. Ciguatera fish poisoning: the risk from an Aotearoa/New Zealand perspective. Toxins 12(1), 50.

Rhodes, L.L., Smith, K.F., Murray, S., Harwood, D.T., Trnski, T., Munday, R., 2017a. The epiphytic genus Gambierdiscus (Dinophyceae) in the Kermadec Islands and Zealandia Regions of the Southwestern Pacific and the associated risk of ciguatera fish poisoning. Mar. Drugs 15(7), 219.

Rhodes, L.L., Smith, K.F., Verma , A., Curley, B.G., Harwood, D.T., Murray, S., Kohli, G.S., Solomona, D., Rongo, T., Munday, R., Murray, S.A., 2017b. A new species of Gambierdiscus (Dinophyceae) from the South-West Pacific: Gambierdiscus honu sp. nov. Harmful Algae 65, 61-70. Rhodes, L.L., Smith, K.F., Verma, A., Murray, S., Harwood, D.T., Trnski, T., 2017c. The dinoflagellate genera Gambierdiscus and Ostreopsis from subtropical Raoul Island and North Meyer Island, Kermadec Islands. New Zeal. J. Mar. Fresh. 51(4), 490-504.

Robertson, A., Garcia, A.C., Flores Quintana, H.A., Smith, T.B., Castillo II, B.F., Reale-Munroe, K., Gulli, J.A., Olsen, D.A., Hooe-Rollman, J.I., Jester, E.L.E., Klimek, B.J., Plakas, S.M., 2014. Invasive lionfish (Pterois volitans): a potential human health threat for ciguatera fish poisoning in tropical waters. Mar. Drugs 12(1), 88.

Rodríguez, F., Fraga, S., Ramilo, I., Rial, P., Figueroa, R.I., Riobó, P., Bravo, I., 2017. Canary Islands (NE Atlantic) as a biodiversity 'hotspot' of Gambierdiscus: implications for future trends of ciguatera in the area. Harmful Algae 67, 131-143.

Rongo, T., Bush, M., van Woesik, R., 2009. Did ciguatera prompt the late holocene polynesian voyages of discovery ? J. Biogeogr., 1-10.

Rongo, T., van Woesik, R., 2011. Ciguatera poisoning in Rarotonga, Southern Cook Islands. Harmful Algae 10(4), 345-355.

Rongo, T., van Woesik, R., 2012. Socioeconomic consequences of ciguatera poisoning in Rarotonga, Southern Cook Islands. Harmful Algae 20, 92-100.

Roué, M., Darius, H.T., Chinain, M., Sibat, M., Amzil, Z., 2016. Ability of giant clams to bioaccumulate ciguatoxins from Gambierdiscus cells. Harmful Algal News 55, 12-13. 
Roué, M., Darius, H.T., Ung, A., Viallon, J., Sibat, M., Hess, P., Amzil, Z., Chinain, M., 2018. Tissue distribution and elimination of ciguatoxins in Tridacna maxima (Tridacnidae, Bivalvia) fed Gambierdiscus polynesiensis. Toxins 10(5), 189.

Ruff, T.A., 1989. Ciguatera in the Pacific: a link with military activities. Lancet 333(8631), 201-205.

Saburova, M., Polikarpov, I., Al-Yamani, F., 2013. New records of the genus Gambierdiscus in marginal seas of the Indian Ocean. Marine Biodiversity Records 6, 1-11.

Sadovy, Y., 1997. Problems of sustainability in grouper fisheries. Proceedings of the Fourth Asian Fisheries Forum, China Ocean Press, Beijing.

Sadovy, Y., 1998. Ciguatera hits Hong Kong live food-fish trade. SPC Live Reef Fish Information Bulletin 4, 51-53.

Sanchez-Henao, A., García-Álvarez, N., Silva Sergent, F., Estévez, P., Gago-Martínez, A., Martín, F., Ramos-Sosa, M., Fernández, A., Diogène, J., Real, F., 2020. Presence of CTXs in moray eels and dusky groupers in the marine environment of the Canary Islands. Aquat. Toxicol. 221, 105427.

Sanchez-Henao, J.A., García-Álvarez, N., Fernández, A., Saavedra, P., Sergent, F.S., Padilla, D., Acosta-Hernández, B., Martel Suárez, M., Diogène, J., Real, F., 2019. Predictive score and probability of CTX-like toxicity in fish samples from the official control of ciguatera in the Canary Islands. Sci. Total Environ. 673, 576-584.

Sanseverino, I., Conduto, D., Pozzoli, L., Dobridic, S., Lettieri, T., 2016. Algal bloom and its economic impact.

Saraya, A., Sintunawa, C., Wacharapluesadee, S., Swangpun, K., Dumrongchua, S., Wilde, H., Hemachudha, T., 2014. Marine fish toxins in Thailand: report of 6 suspected ciguatera cases. Case Reports in Clinical Medicine 3, 286 -292.

Seger, A., Dowsett, N., Tumbull, A., 2019. National ciguatera research strategy: reducing the incidence of ciguatera in Australia through improved risk management. South Australian Research and Development Institute (SARDI), 32.

Sève, P., Tremblay, A., Rousset, H., Turquet, J., 2011. Ichthyosarcotoxisme par ciguatera à l'île de la Réunion de 2000 à 2010. À propos de 230 cas. Rev. Med. Int. 32(1). 
Silva, M., Rodriguez, I., Barreiro, A., Kaufmann, M., Neto, A.I., Hassouani, M., Sabour, B., Alfonso, A., Botana, L.M., Vasconcelos, V., 2015. First report of ciguatoxins in two starfish species : Ophidiaster ophidianus and Marthasterias glacialis. Toxins 7, 3740-3757.

Silva, S.E., 1956. Contribution à l'étude du microplankton de Dakar et des regions maritimes voisines. Bull. Inst. Fr. Afr. Noire. Ser. A. Sci. Nat. 18, 335-371.

Skinner, M., 2015. Ciguatera fish poisoning, in specific Pacific Island Countries, from 2009 to 2014., 34.

Skinner, M.P., Brewer, T.D., Johnstone, R., Fleming, L.E., Lewis, R.J., 2011. Ciguatera fish poisoning in the Pacific Islands (1998 to 2008). PLOS Neglect. Trop. D. 5(12), e1416.

Smith, K.F., Biessy, L., Argyle, P.A., Trnski, T., Halafihi, T., Rhodes, L.L., 2017. Molecular identification of Gambierdiscus and Fukuyoa (Dinophyceae) from environmental samples. Mar. Drugs 15(8), 243.

Smith, K.F., Rhodes, L., Verma, A., Curley, B.G., Harwood, D.T., Kohli, G.S., Solomona, D., Rongo, T., Munday, R., Murray, S.A., 2016. A new Gambierdiscus species (Dinophyceae) from Rarotonga, Cook Islands: Gambierdiscus cheloniae sp. nov. Harmful Algae 60, 45-56.

Soliño, L., Widgy, S., Pautonnier, A., Turquet, J., Loeffler, C.R., Flores Quintana, H.A., Diogène, J., 2015. Prevalence of ciguatoxins in lionfish (Pterois spp.) from Guadeloupe, Saint Martin, and Saint Barthélémy Islands (Caribbean). Toxicon 102, 62-68.

Sozzi, G., Marotta, P., Aldeghi, D., Tredici, G., Calvi, L., 1988. Polyneuropathy secondary to ciguatoxin poisoning. Ital. J. Neurol. Sci. 9(5), 491-495.

Spanier, E., Finkelstein, Y., Raikhlin-Eisenkraftn, B., 1989. Toxicity of the saupe, Sarpa salpa (Linnaeus, 1758), on the Mediterranean Coast of Israel. J. Fish Biol. 34, 635-636.

Stafford, R., 2019. The epidemiology of ciguatera fish poisoning in Australia. National ciguatera research strategy: reducing the incidence of ciguatera in Australia through improved risk management, 30.

Stempf, E., 2015. Incidence des formes chroniques de la ciguatera au sein de la population réunionnaise de 2000 à 2014. Médecine humaine et pathologie dumas-01412160, 58. 
Sumner, J., Turnbull, A., Dowsett, N., 2011. Hazards affecting Australian seafood. South Australian Research and Development Institute (SARDI) Part 1 Updates to existing hazard sheets, 15-20.

Sydney Fish Market, 2015. Seafood handling guidelines.

Tabbada, R., 2015. Harmful Algal Bloom (HAB) Activities - Country Report: Philippines. RAS Workshop on Ciguatera Fish Poisoning (CFP) Field Monitoring.

Ten-Hage, L., Turquet, J., Quod, J.P., Couté, A., 2000a. Coolia areolata sp. nov. (Dinophyceae), a new sand-dwelling dinoflagellate from the Southwestern Indian Ocean. Phycologia 39(5), 377-383.

Ten-Hage, L., Turquet, J., Quod, J.P., Puiseux-Dao, S., Couté, A., 2000b. Prorocentrum borbonicum sp. nov. (Dinophyceae), a new toxic benthic dinoflagellate from the Southwestern Indian Ocean. Phycologia 39(4), 296-301.

Tester, P.A., Berdalet, E., Litaker, R.W., 2020a. Climate change and benthic harmful microalgae. Harmful Algae 91, 101655.

Tester, P.A., Dechraoui-Bottein, M.-Y., Lemée, R., 2018. Regional workshop on monitoring and management strategies for benthic HABs. Harmful Algal News 60, 16.

Tester, P.A., Feldman, R.L., Nau, A.W., Kibler, S.R., Litaker, W.R., 2010. Ciguatera fish poisoning and sea surface temperatures in the Caribbean Sea and the West Indies. Toxicon 56(5), 698-710.

Tester, P.A., Vandersea, M.W., Buckel, C.A., Kibler, S.R., Holland, W.C., Davenport, E.D., Clark, R.D., Edwards, K.F., Taylor, J.C., Vander Pluym, J.L., Hickerson, E.L., Litaker, W.R., 2013. Gambierdiscus (Dinophyceae) species diversity in the Flower Garden Banks National Marine Sanctuary, Northern Gulf of Mexico, USA. Harmful Algae 29, 1-9.

Tester, P.A., Wicklaffe, L., Jossart, J., Rhodes, L.L., Enevoldsen, H., Adachi, M., Nishimura, T., Rodriguez, F., Chinain, M., Litaker, R.W., 2020b. Global distribution of the genera Gambierdiscus and Fukuyoa. 18th International Conference on Harmful Algae, 2018, Nantes, France in press, issha.org/publications-resources/conference-proceedings/.

Thomassin, B.A., Ali Halidi, M.E., Quod, J.P., Maggiorani, J.M., Berland, B., Grzebyk, D., Coqueugniot, J., 1992. Evolution of Gambierdiscus toxicus populations in the coral reef complex of Mayotte Island (SW Indian Ocean) during the 1985-1991 period. Bull. Soc. Pathol. Exot. 85(5 Pt 2), $449-452$. 
Thompson, C.A., Jazuli, F., Taggart, L.R., Boggild, A.K., 2017. Ciguatera fish poisoning after Caribbean travel. CMAJ 189(1), E19-E21.

Ting, J.Y., Brown, A.F., Pearn, J.H., 1998. Ciguatera poisoning: an example of a public health challenge. Aust. N.Z. J. Publ. Heal. 22(1), 140-142.

Ting, J.Y.S., Brown, A.F.T., 2001. Ciguatera poisoning: a global issue with common management problems. Eur. J. Emerg. Med. 8, 295-300.

Tonge, J.I., Battey, Y., Forbes, J.J., Grant, E.M., 1967. Ciguatera poisoning: a report of two outbreaks and a probable fatal case in Queensland. Aust. Med. J. 2, 1088.

Tosteson, T.R., 1995. The diversity and origins of toxins in ciguatera fish poisoning. Puerto Rico Health Sciences Journal 14(2), 117-129.

Tosteson, T.R., 2004. Caribbean ciguatera: a changing paradigm. Rev. Biol. Trop. 52(1), 109-113.

Tudó, A., Toldrà, A., Andree, K.B., Rey, M., Fernàndez-Tejedor, M., Compàs, M., Diogène, J., 2018. First report of Gambierdiscus in the Western Mediterranean Sea (Balearic Islands). Harmful Algal News 59, 22-23.

Turquet, J., Quod, J.-P., Ten-Hage, L., Dahalani, Y., Wendling, B., 2001. Example of a Gambierdiscus toxicus flare-up following the 1998 coral bleaching event in Mayotte Island (Comoros, South-West Indian Ocean). Harmful Algal Blooms, 364-366.

Turquet, J., Quod, J.P., Couté, A., Faust, M.A., 1998. Assemblage of benthic dinoflagellates and monitoring of harmful species in Reunion Island, SW Indian Ocean, 1993-1996, In: Reguera, B., Blanco, J., Fernandez, M.L., Wyatt, T. (Eds.), Proceedings of the 8th International Conference on Harmful Algae (Vigo, Spain). Xunta de Galicia and Intergovernmental Oceanographic Commission of UNESCO, Vigo, Spain, pp. 44-47.

US Food and Drug Administration (FDA), 2019. Fish and fishery products hazards and control guidance. Chapter 6: Natural Toxins, 1-19.

Villareal, T.A., Hanson, S., Qualia, S., Jester, E.L.E., Granade, H.R., Dickey, R.W., 2007. Petroleum production platforms as sites for the expansion of ciguatera in the Northwestern Gulf of Mexico. Harmful Algae 6(2), 253-259. 
Wang, D.-Z., 2008. Neurotoxins from Marine Dinoflagellates: A Brief Review. Mar. Drugs 6(2), 349371.

Wasay, M., Sarangzai, A., Siddiqi, A., Nizami, Q., 2008. Ciguatera fish poisoning with elevated muscle enzymes and abnormal spinal MRI. Southeast Asian J. Trop. Med. Public Health 39(2), 307309.

Wheeler, J.F., 1953. The problem of poisonous fishes. Mauritius-Seychelles Fish Survey 1, 44-48.

Wong, C.K., Hung, P., Lee, K.L., Kam, K.M., 2005. Study of an outbreak of ciguatera fish poisoning in Hong Kong. Toxicon 46(5), 563-571.

Wong, C.K., Hung, P., Lo, J.Y.C., 2014. Ciguatera fish poisoning in Hong Kong-A 10-year perspective on the class of ciguatoxins. Toxicon 86, 96-106.

World Tourism Organization (WTO), 2017. International tourism, number of arrivals. https://data.worldbank.org/indicator/st.int.arvl. Last accessed 27/11/2019

Wun, Z., 2017. Review of ciguatera fish poisoning in Hong Kong. Communication Diseases Watch $14,42-43$.

Yasumoto, T., 1998. Fish poisoning due to toxins of microalgal origins in the Pacific. Toxicon 36, $1515-1518$.

Yau, $\quad$ A., $2010 . \quad$ Ciguatera $\quad$ fish https://www.cfs.gov.hk/english/multimedia/multimedia pub/multimedia pub fsf $5101 \mathrm{html}$. Last accessed 31/01/2020

Yau, A., 2012. Ciguatoxins, fish and food poisoning. https://www.cfs.gov.hk/english/multimedia/multimedia_pub/multimedia_pub_fsf_69_02.html. Last accessed 31/01/2020

Yogi, K., Oshiro, N., Inafuku, Y., Hirama, M., Yasumoto, T., 2011. Detailed LC-MS/MS analysis of ciguatoxins revealing distinct regional and species characteristics in fish and causative alga from the Pacific. Analytical Chemistry 83(23), 8886-8891.

Yogi, K., Oshiro, N., Matsuda, S., Sakugawa, S., Matsuo, K., Yasumoto, T., 2013. Toxin profiles in fish implicated in ciguatera fish poisoning in Amami and Kakeroma Islands, Kagoshima Prefecture, Japan. Shokuhin Eiseigaku Zasshi. Journal of the Food Hygienic Society of Japan 54(6), 385-391. 
Yogi, K., Sakugawa, S., Oshiro, N., Ikehara, T., Sugiyama, K., Yasumoto, T., 2014. Determination of toxins involved in Ciguatera Fish Poisoning in the Pacific by LC/MS. Journal of AOAC International 97(2), 398-402.

Yong, H.L., Mustapa, N.I., Lee, L.K., Lim, Z.F., Tan, T.H., Usup, G., Gu, H., Litaker, R.W., Tester, P.A., Lim, P.T., Leaw, C.P., 2018. Habitat complexity affects benthic harmful dinoflagellate assemblages in the fringing reef of Rawa Island, Malaysia. Harmful Algae 78, 56-68.

Zlotnick, B.A., Hintz, S., Park, D.L., Auerbach, P.S., 1995. Ciguatera poisoning after ingestion of imported jellyfish: diagnostic application of serum immunoassay. Wild. Environ. Med. 6(3), 288-294. 

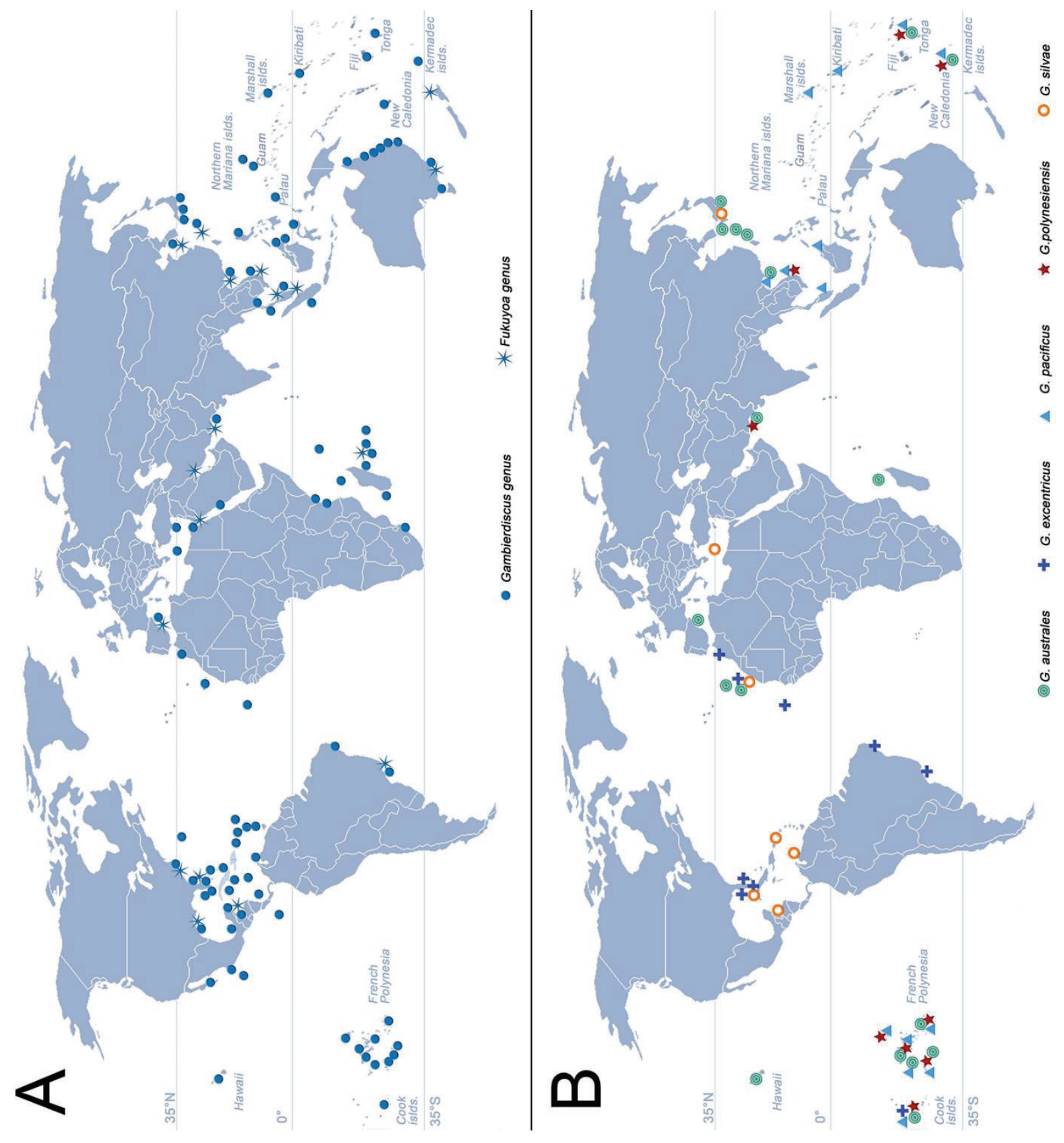


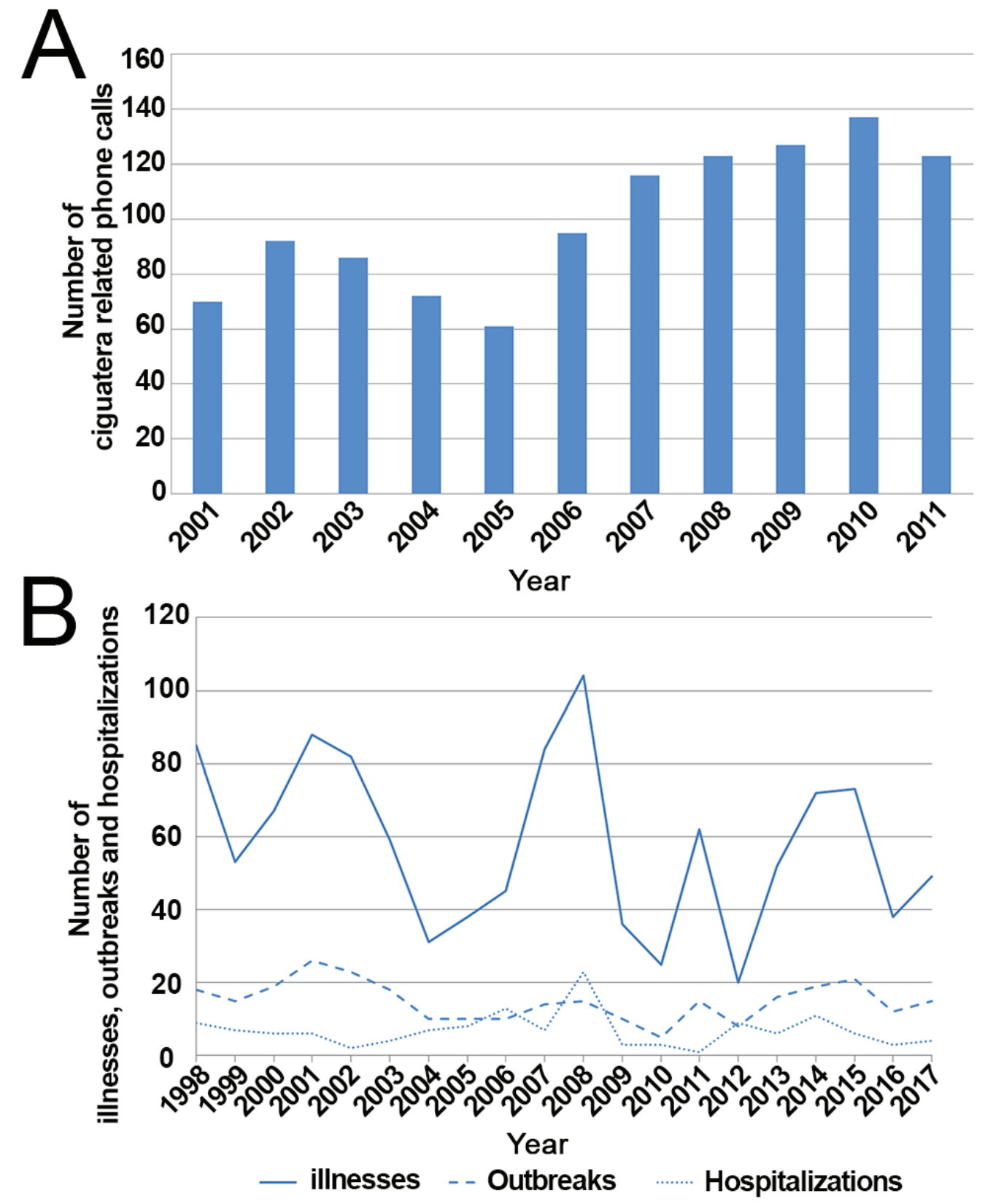








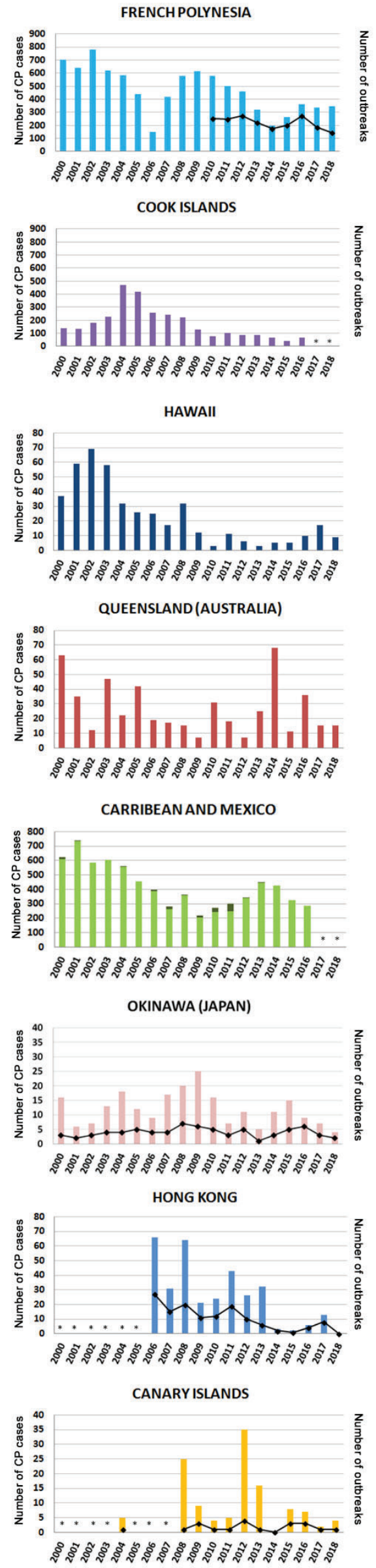


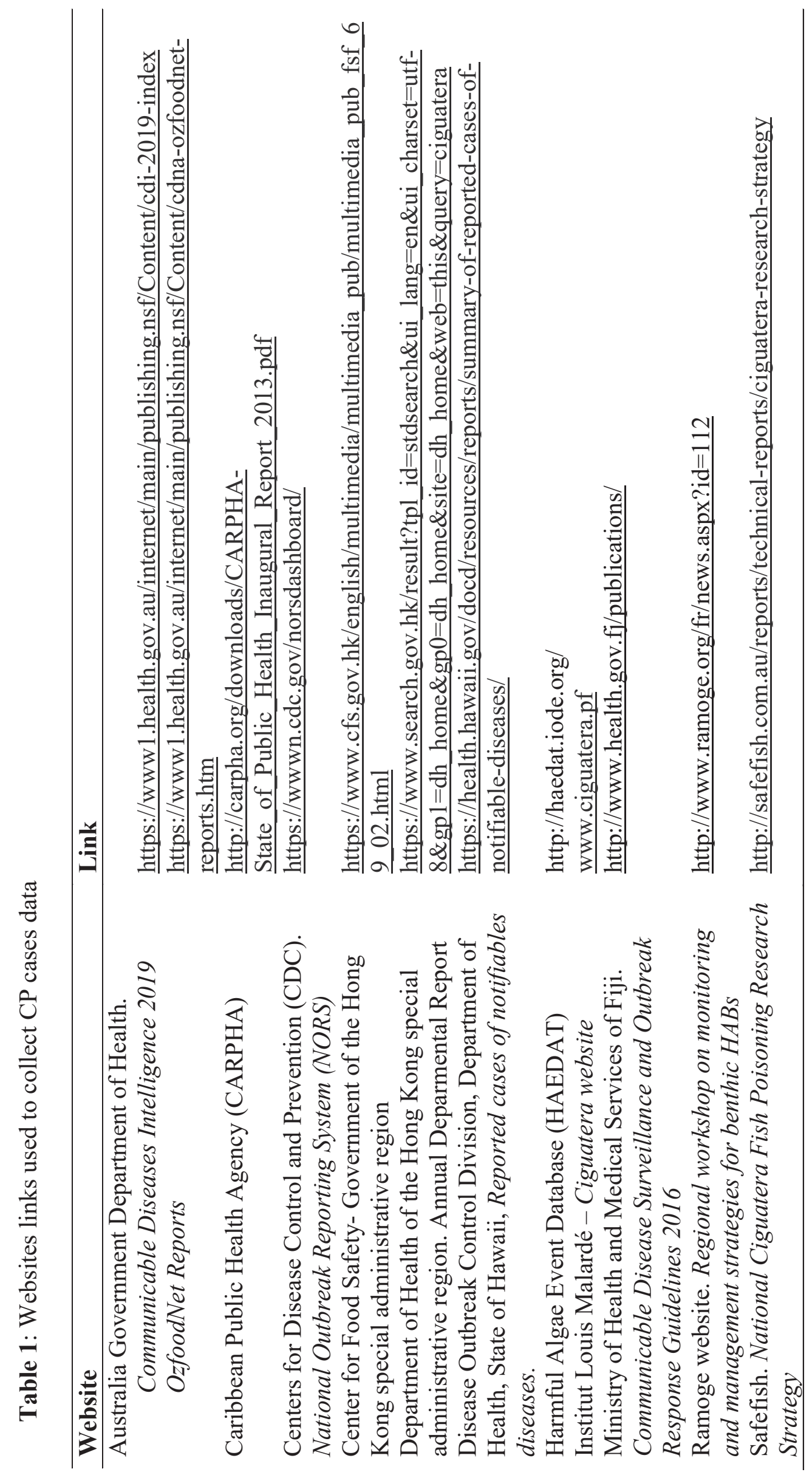




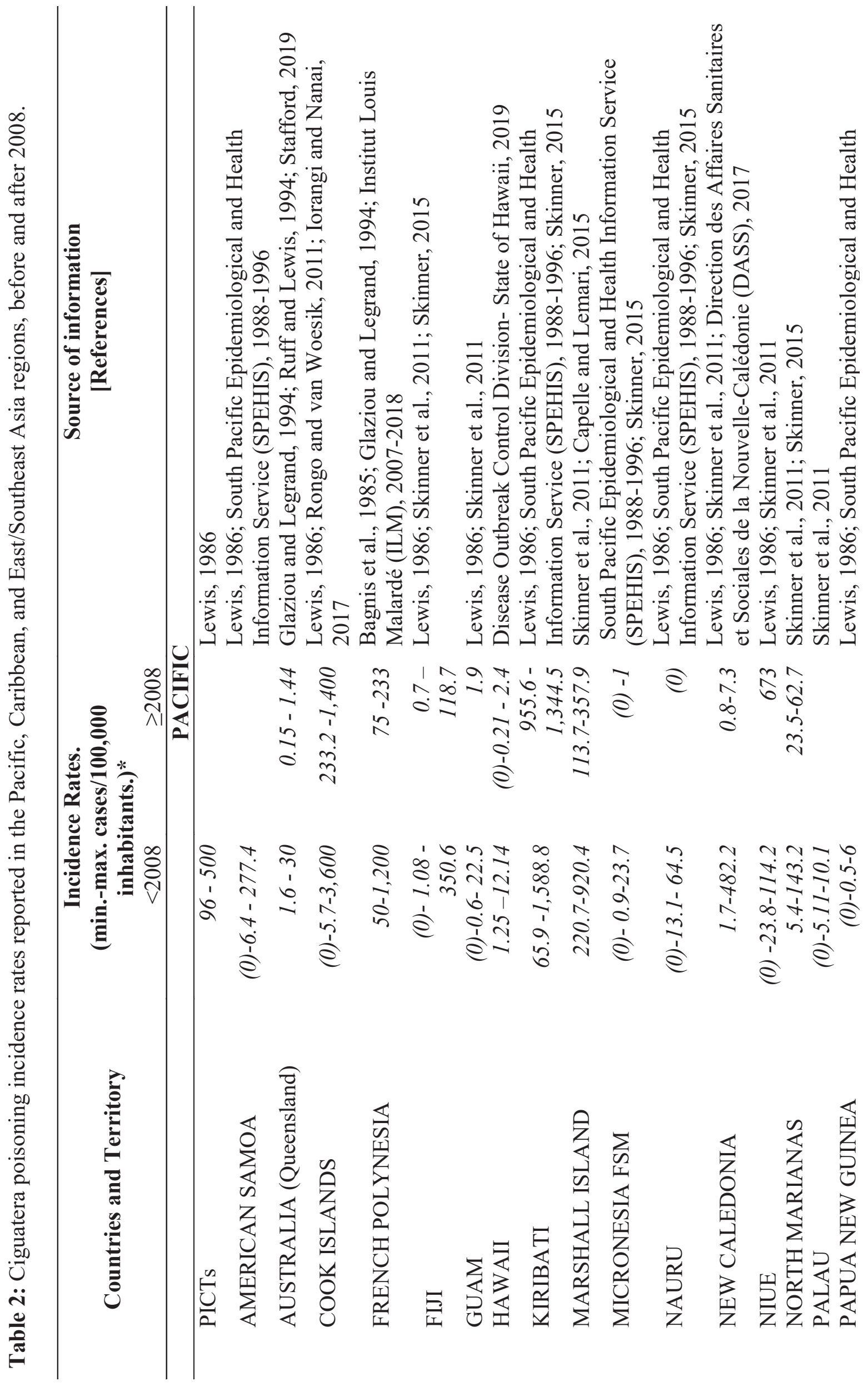




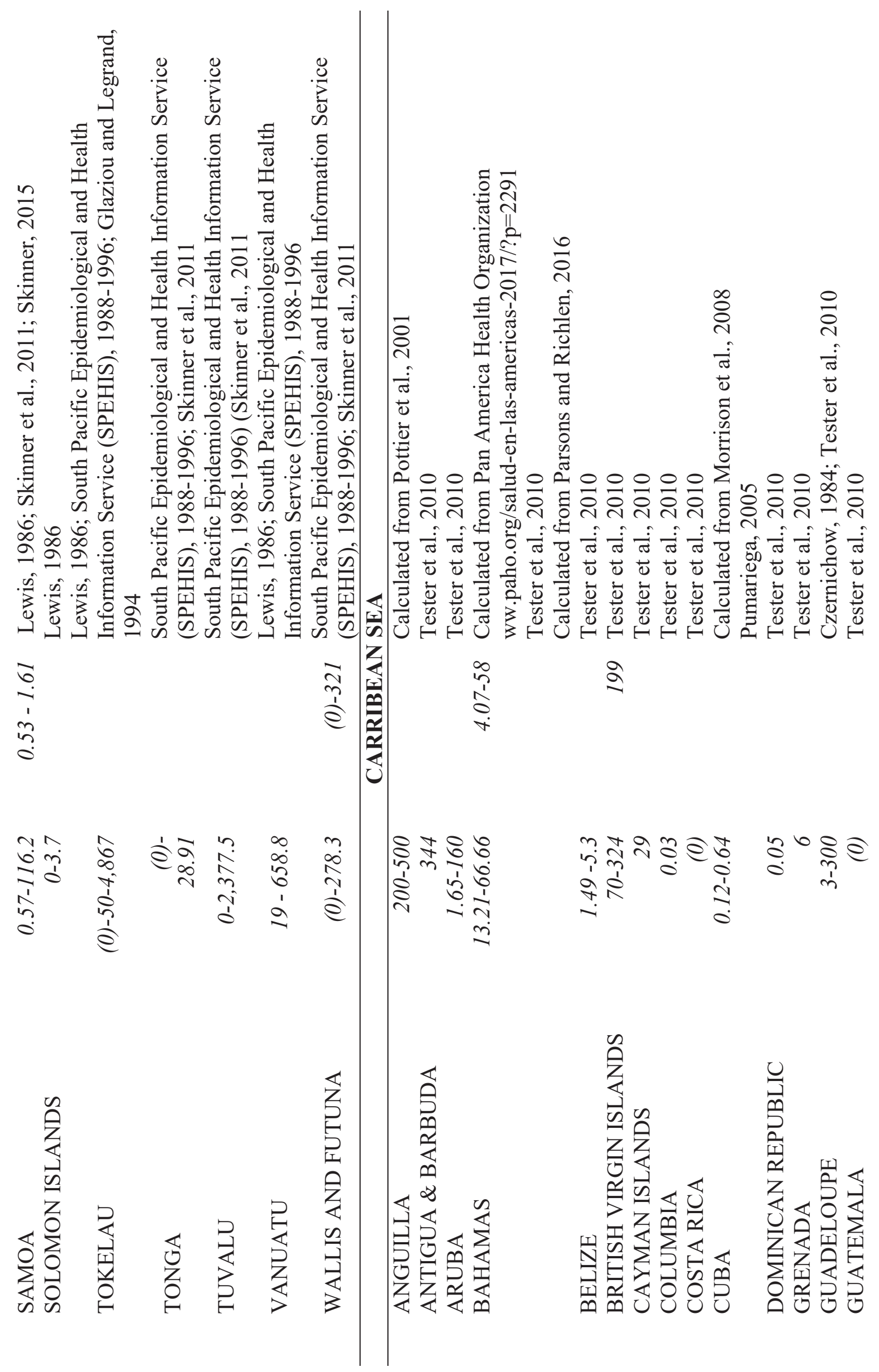




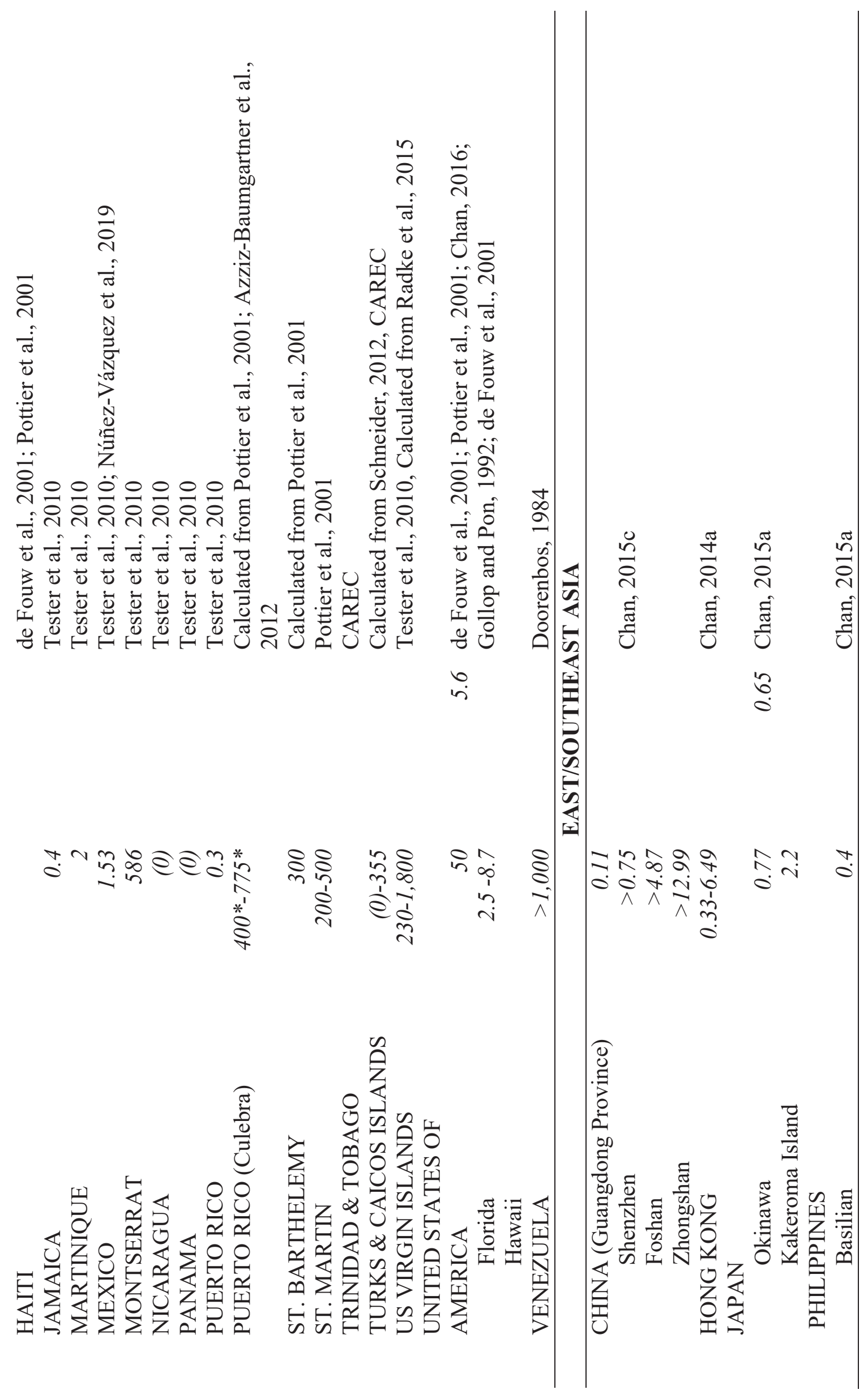




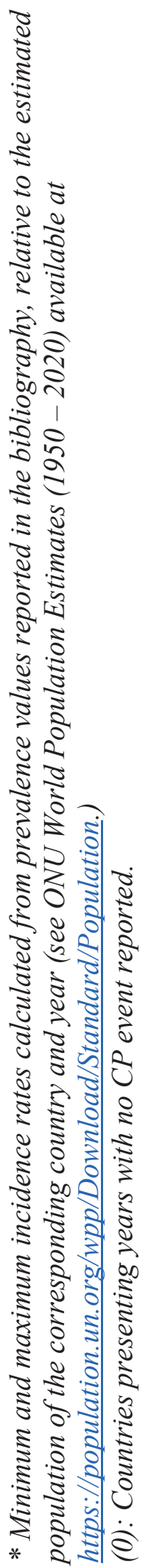




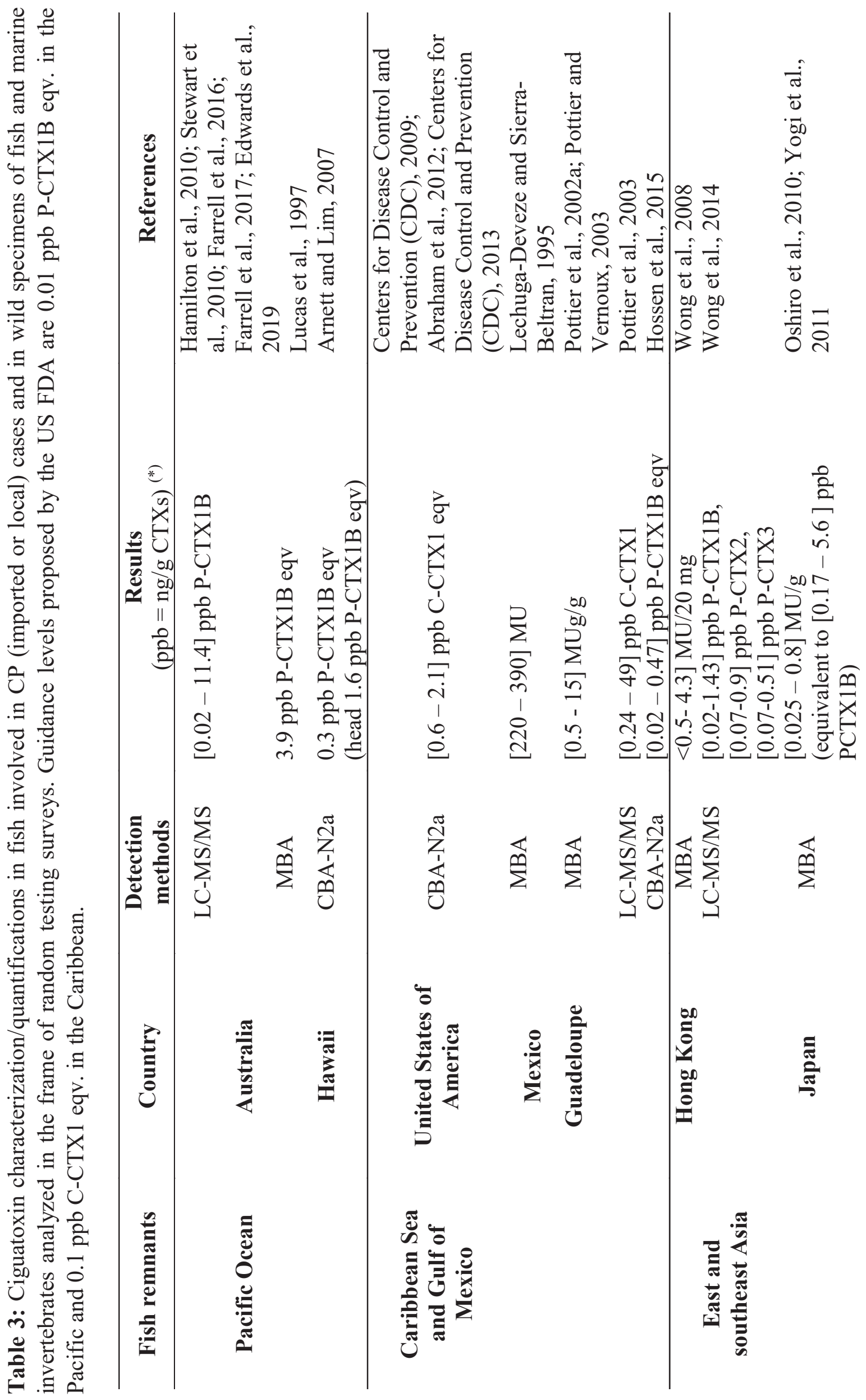




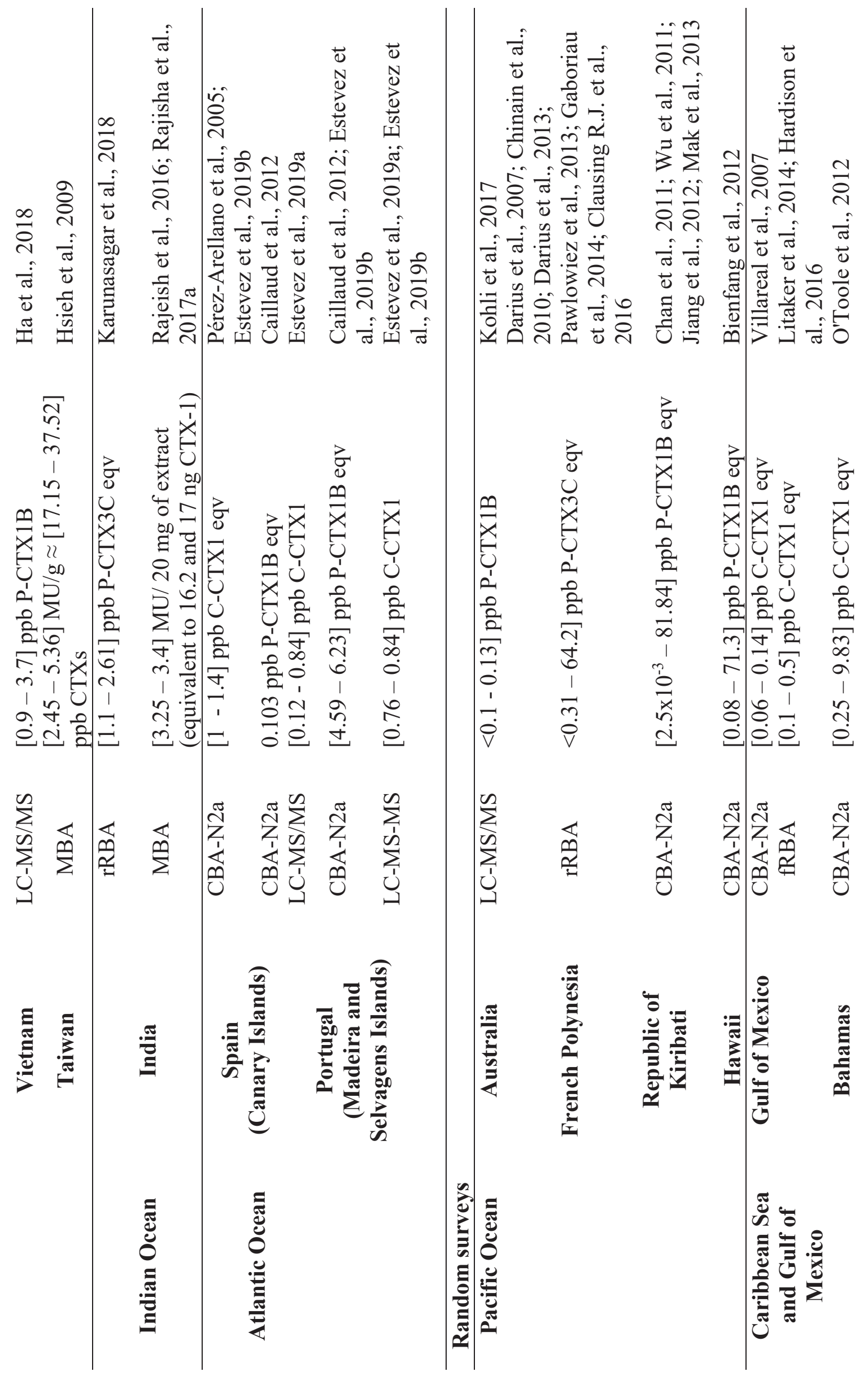




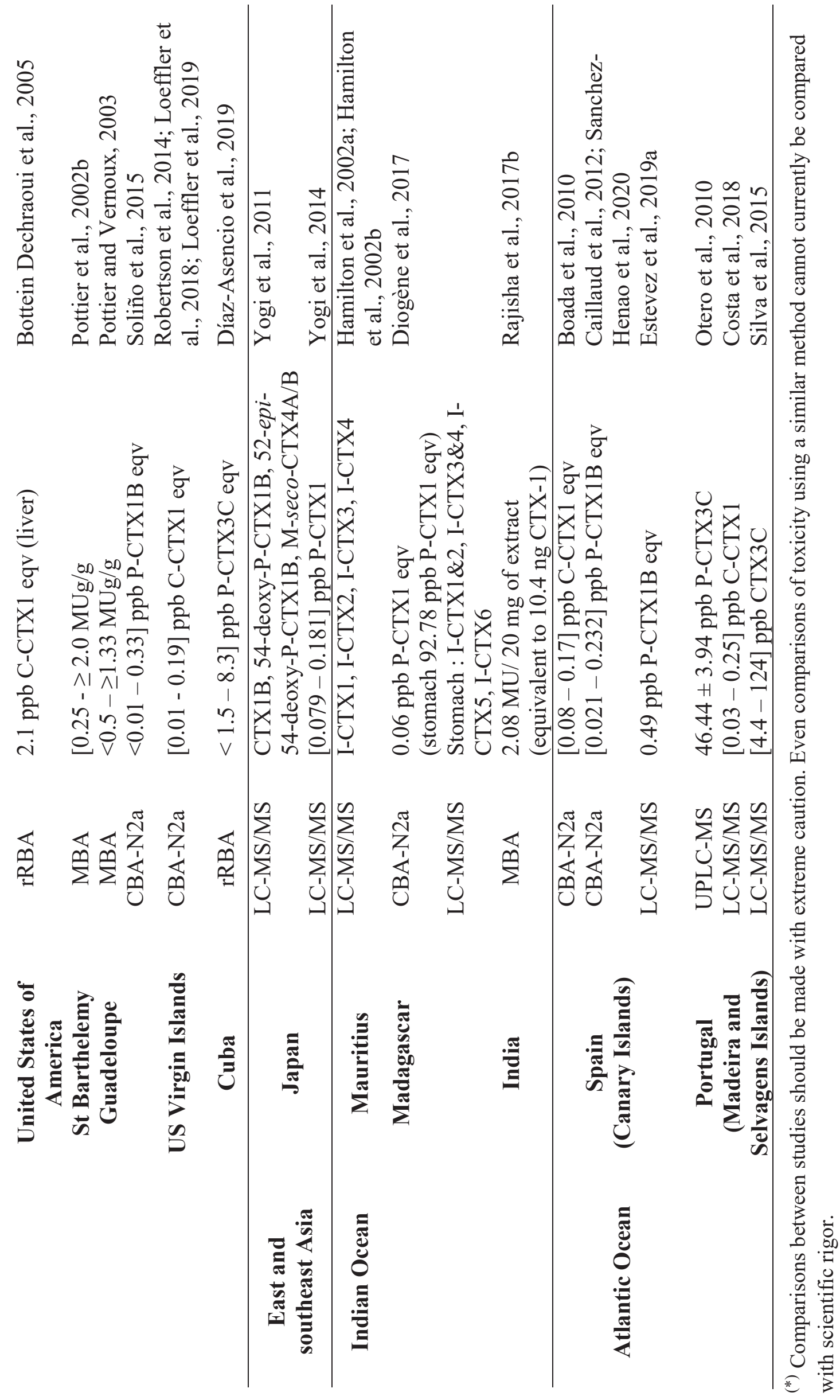




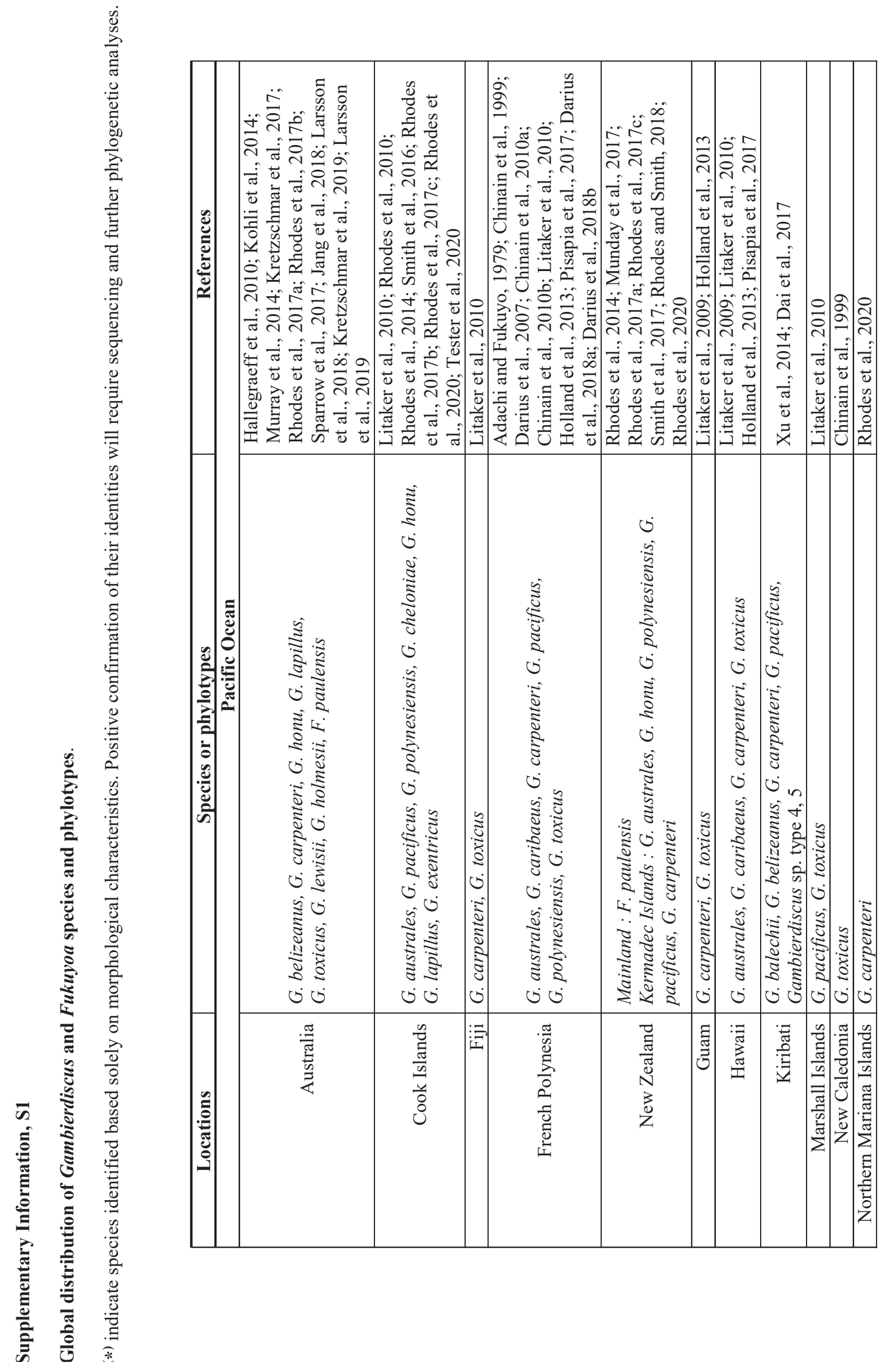




\begin{tabular}{|c|c|c|c|c|c|c|c|c|c|c|c|c|c|c|c|}
\hline$\frac{\dot{d}}{\tilde{\sigma}}$ & 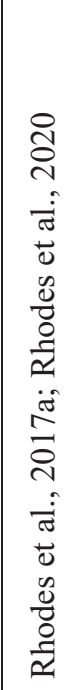 & 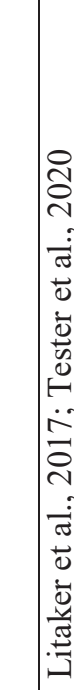 & 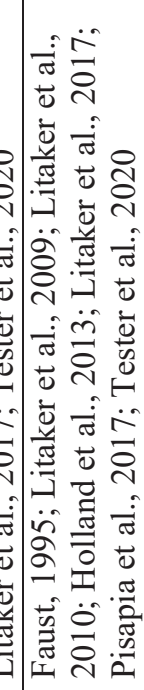 & 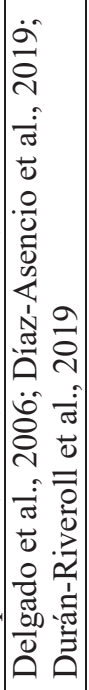 & 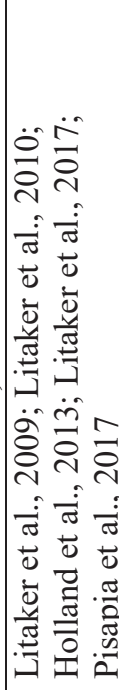 & 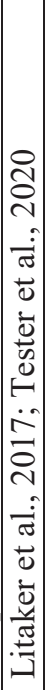 & 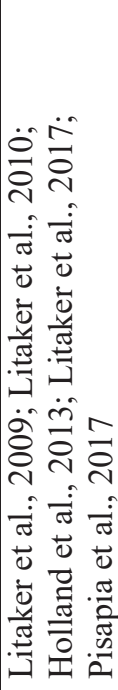 & 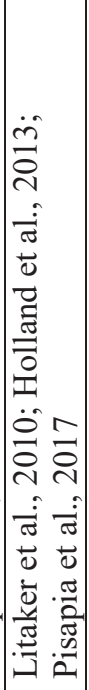 & 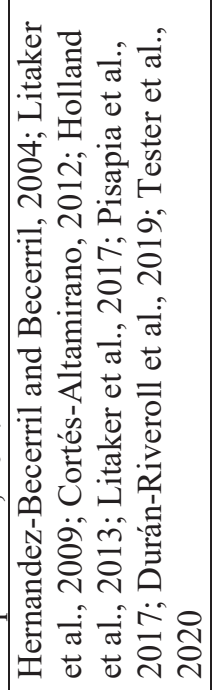 & 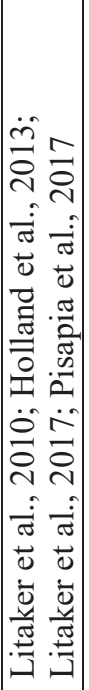 & 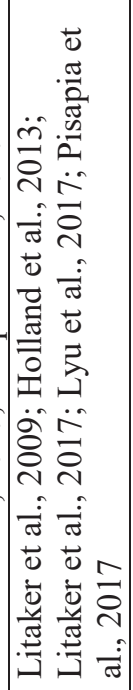 & 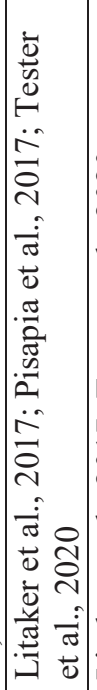 & 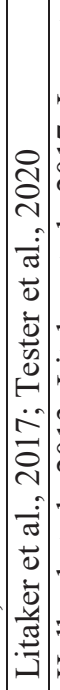 & 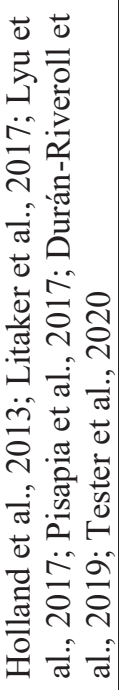 & 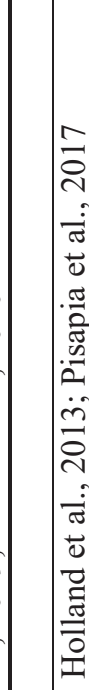 \\
\hline 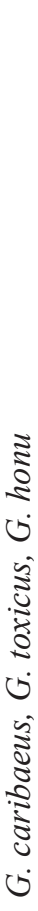 & 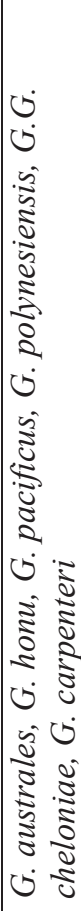 & 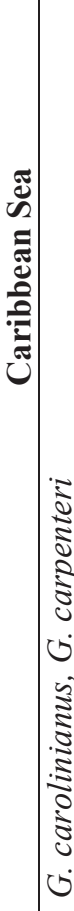 & 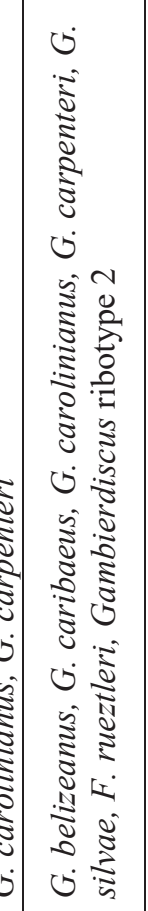 & 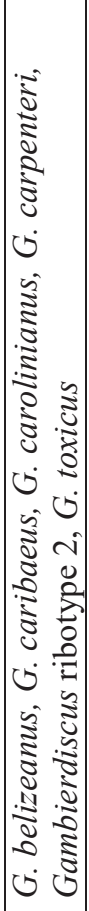 & 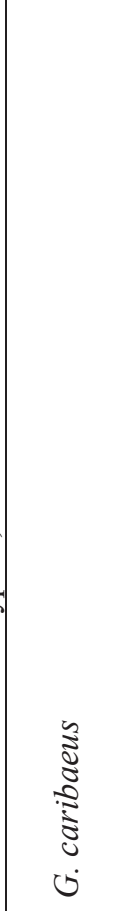 & 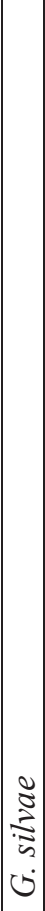 & 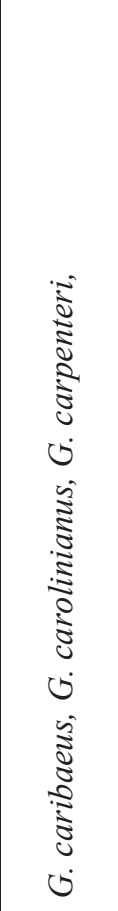 & 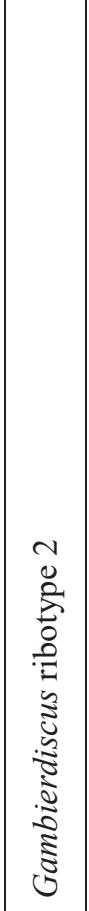 & 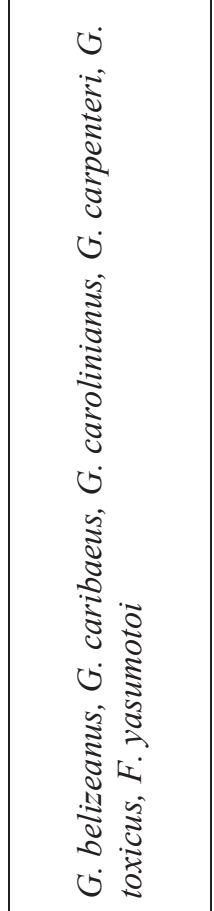 & $\begin{array}{l}1 \\
0 \\
0 \\
0 \\
0 \\
0 \\
0 \\
0 \\
0 \\
0 \\
0 \\
0 \\
0 \\
0 \\
0 \\
0 \\
0\end{array}$ & 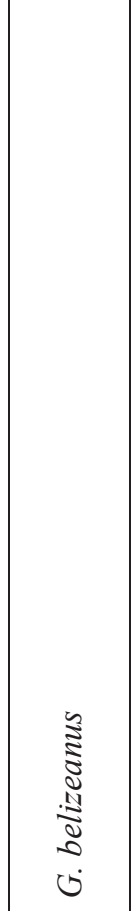 & 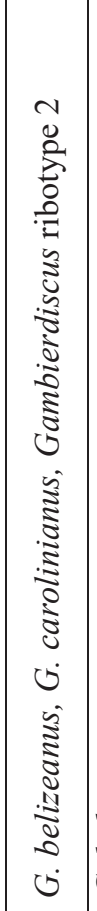 & 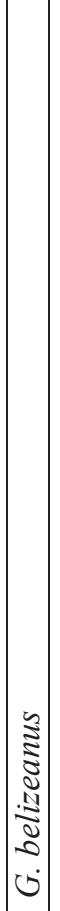 & 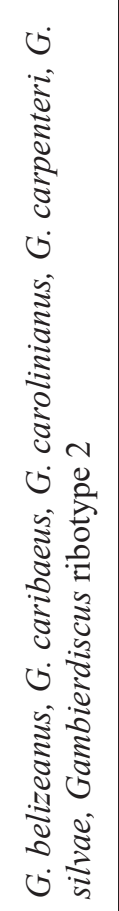 & 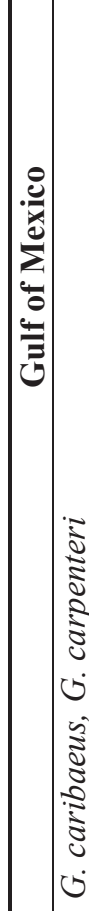 \\
\hline $\bar{\sigma}$ & $\begin{array}{l}\mathscr{E} \\
\stackrel{5}{0} \\
\stackrel{0}{\bullet}\end{array}$ & 胥 & $\stackrel{\mathscr{N}}{\overline{0}}$ & $\stackrel{\mathscr{a}}{\Xi}$ & 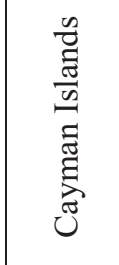 & 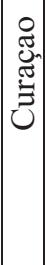 & 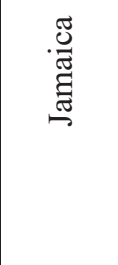 & 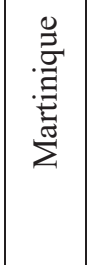 & 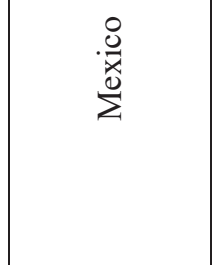 & $\begin{array}{l}\frac{0}{2} \\
\frac{0}{2} \\
\frac{0}{0} \\
2\end{array}$ & 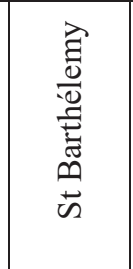 & 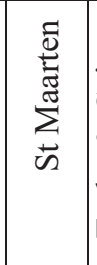 & 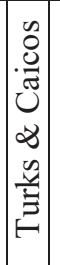 & 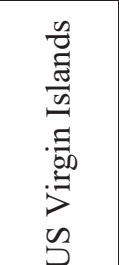 & : \\
\hline
\end{tabular}




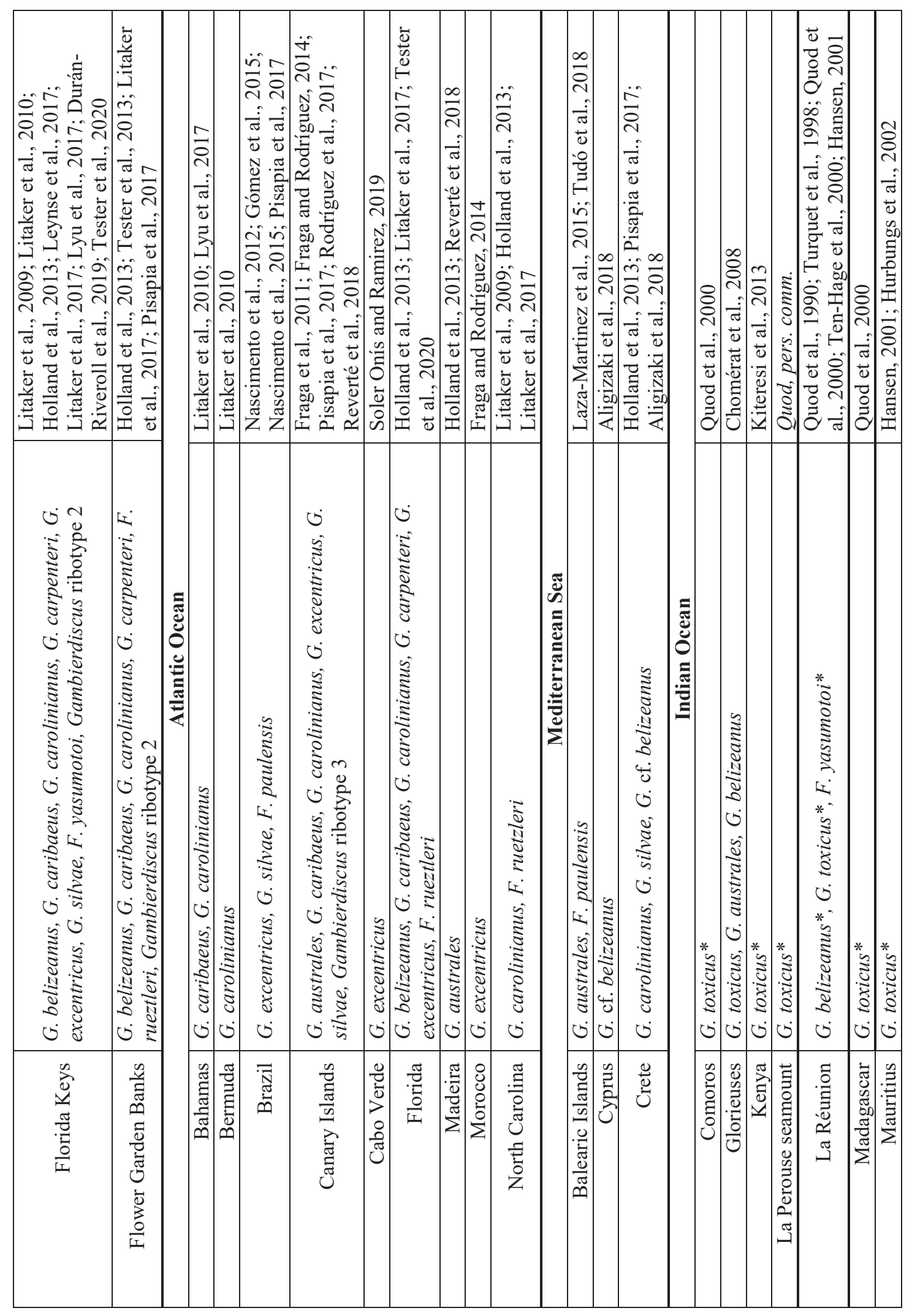




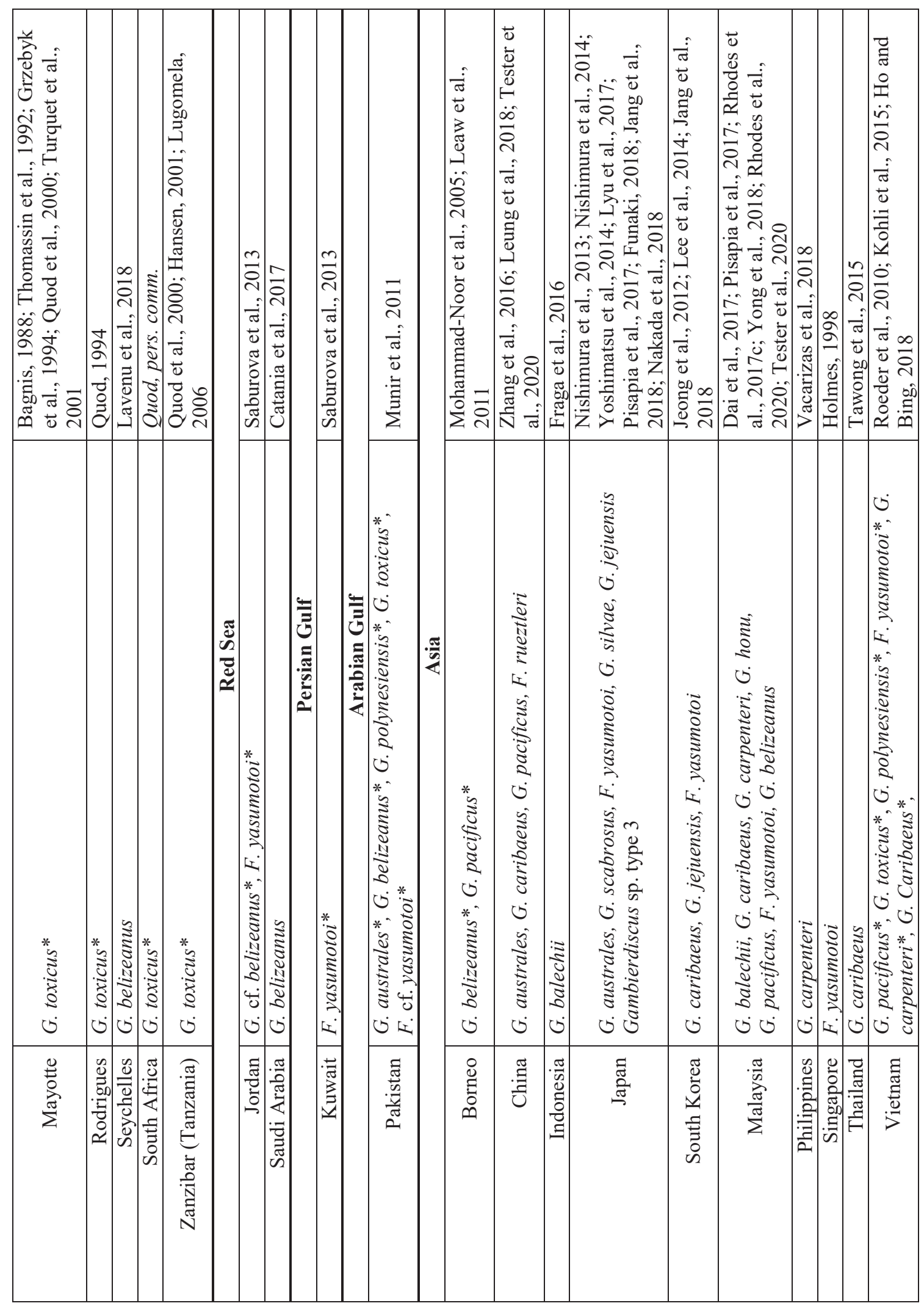




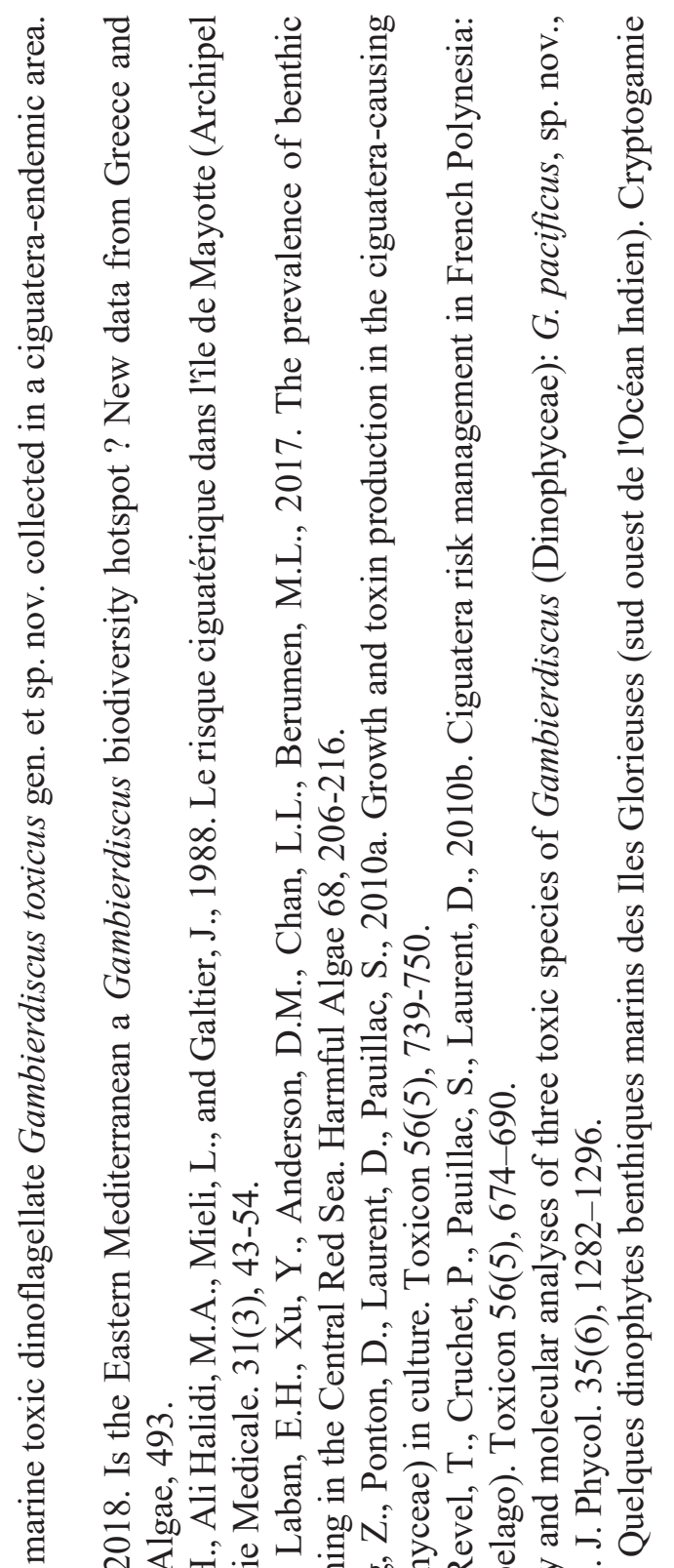

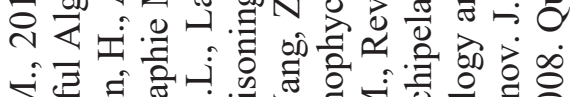

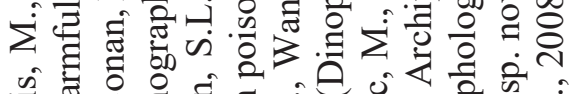

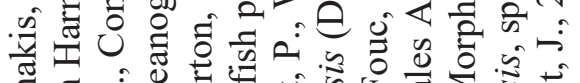
ठี

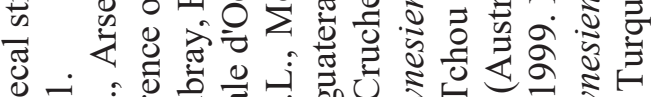

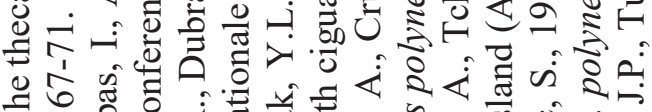
을

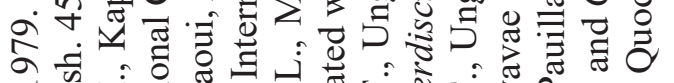

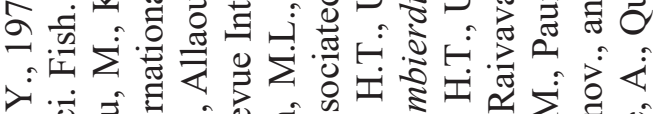
خ.j.

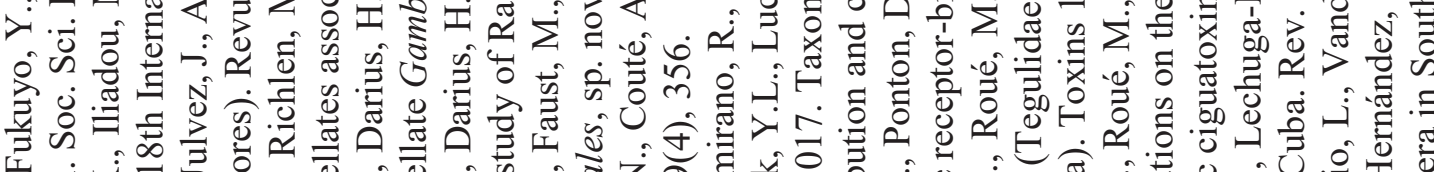
I $\dot{-1}=0$ थ

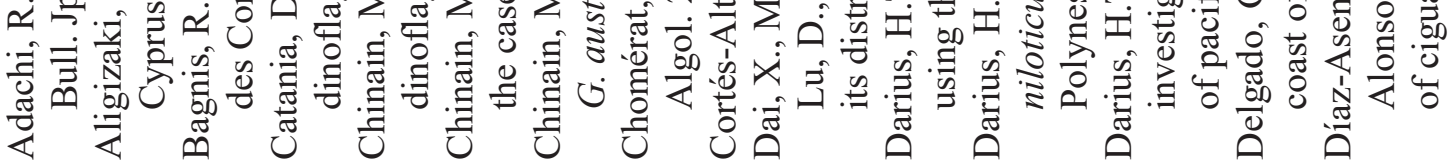




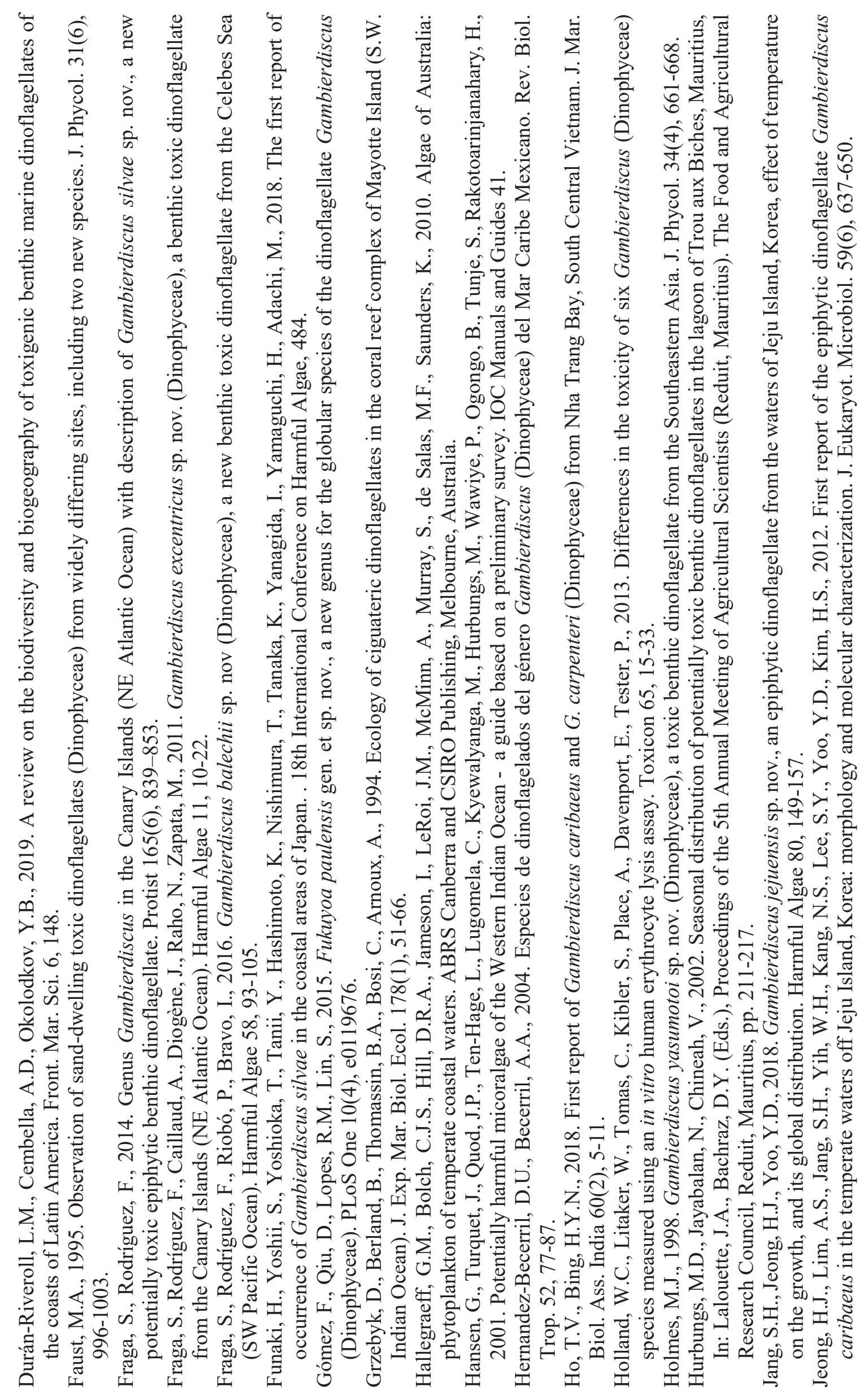




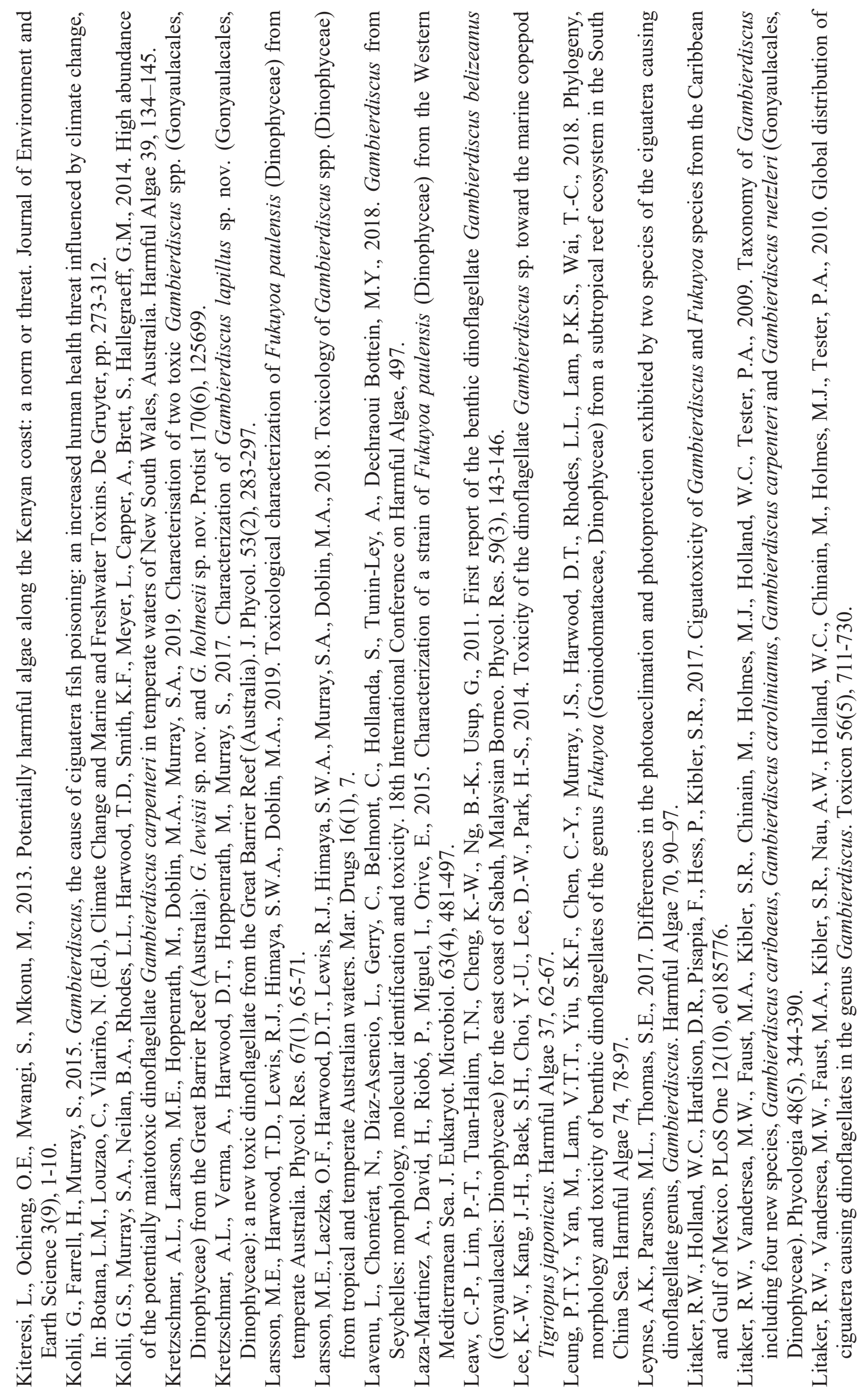




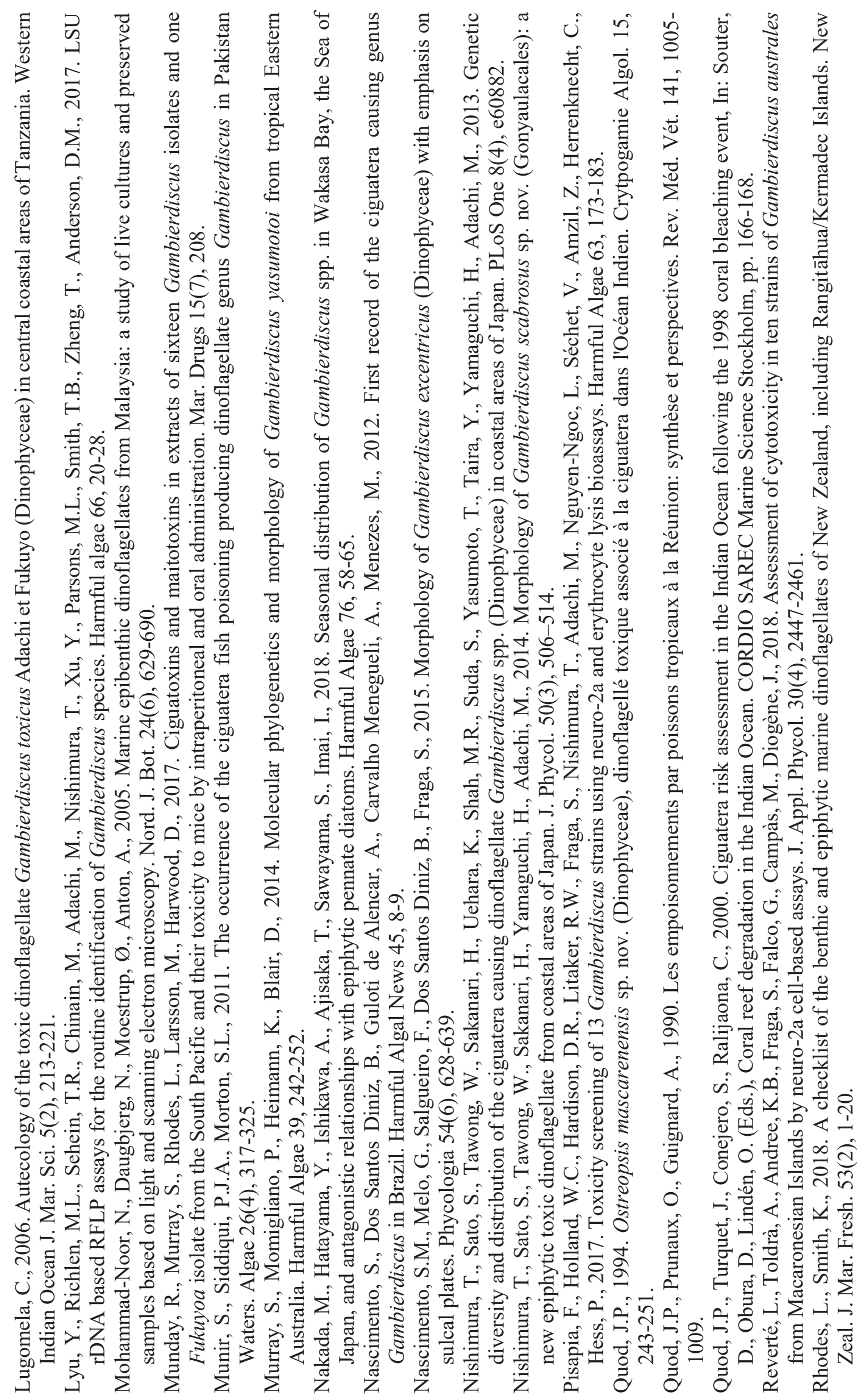




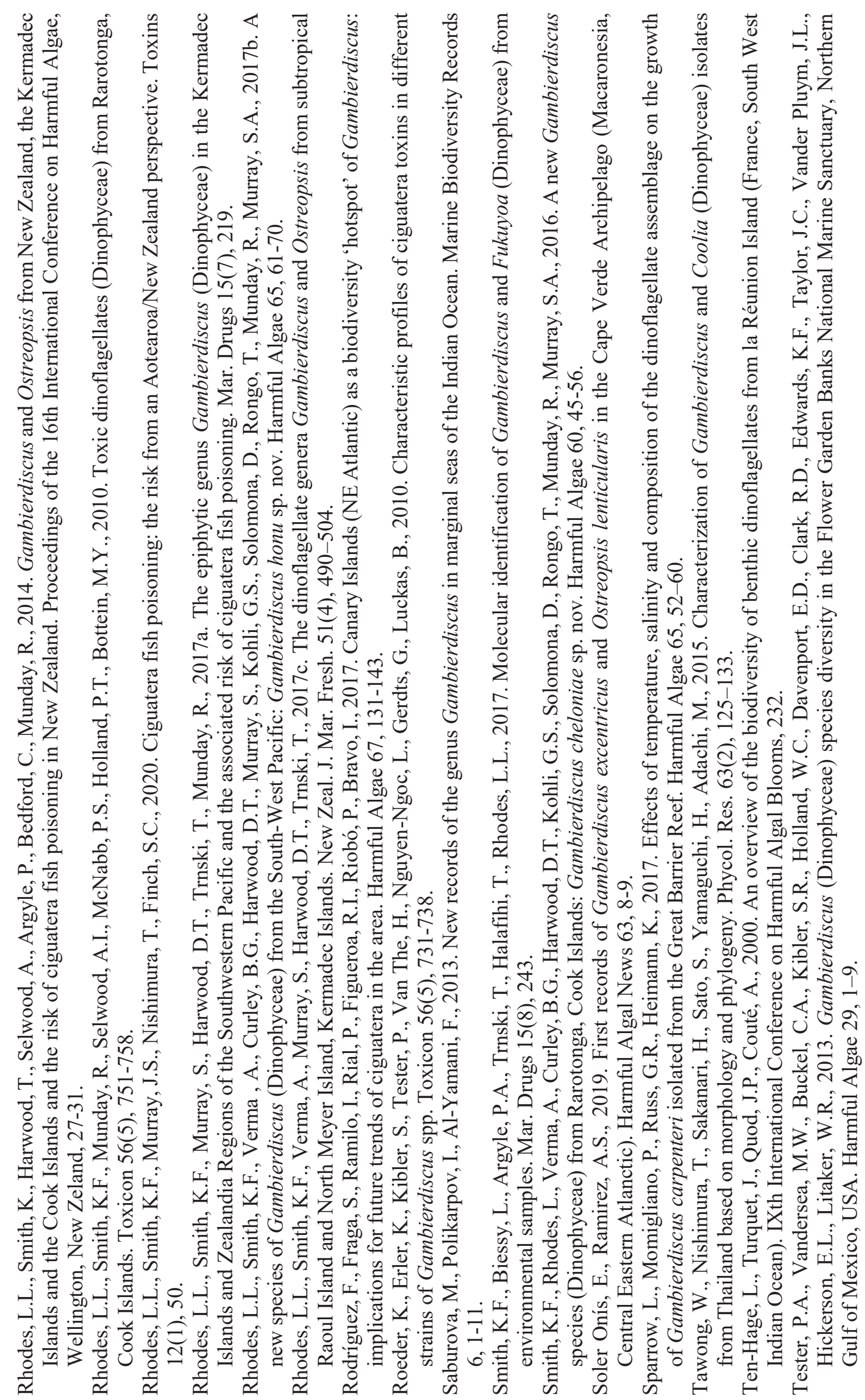




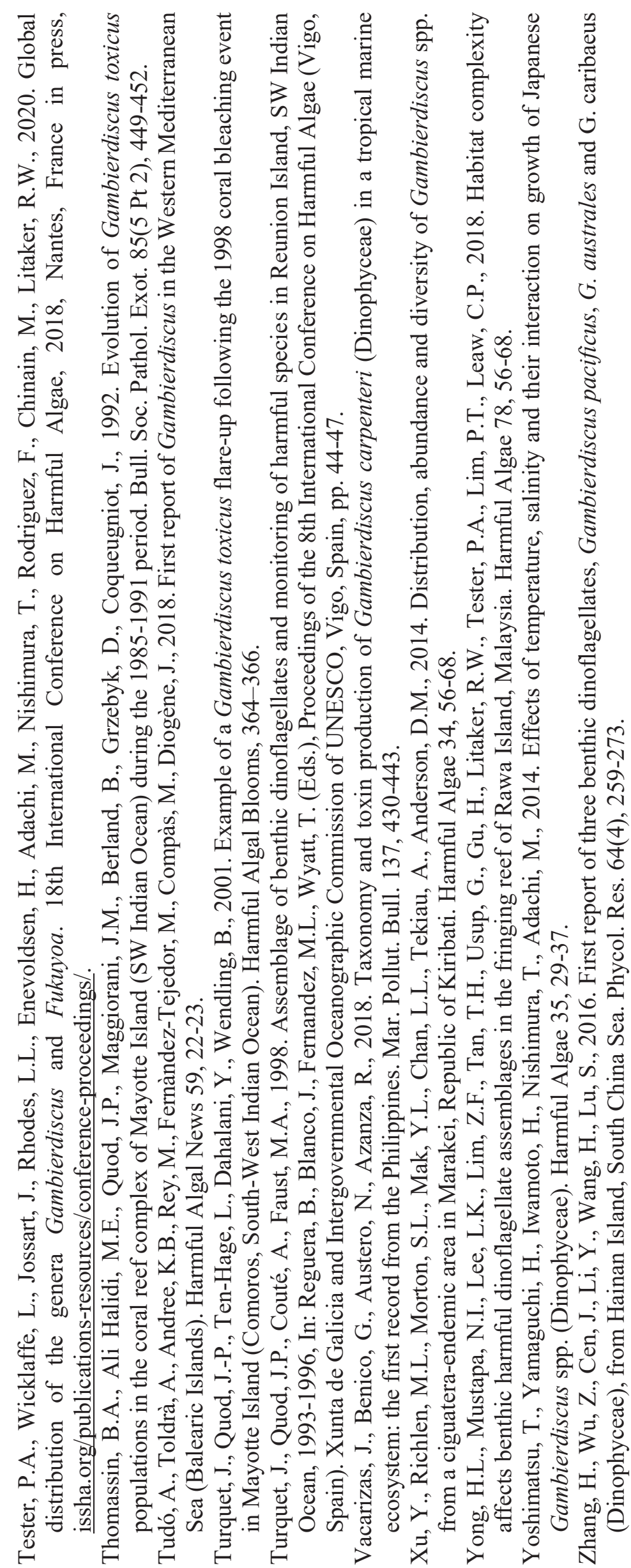




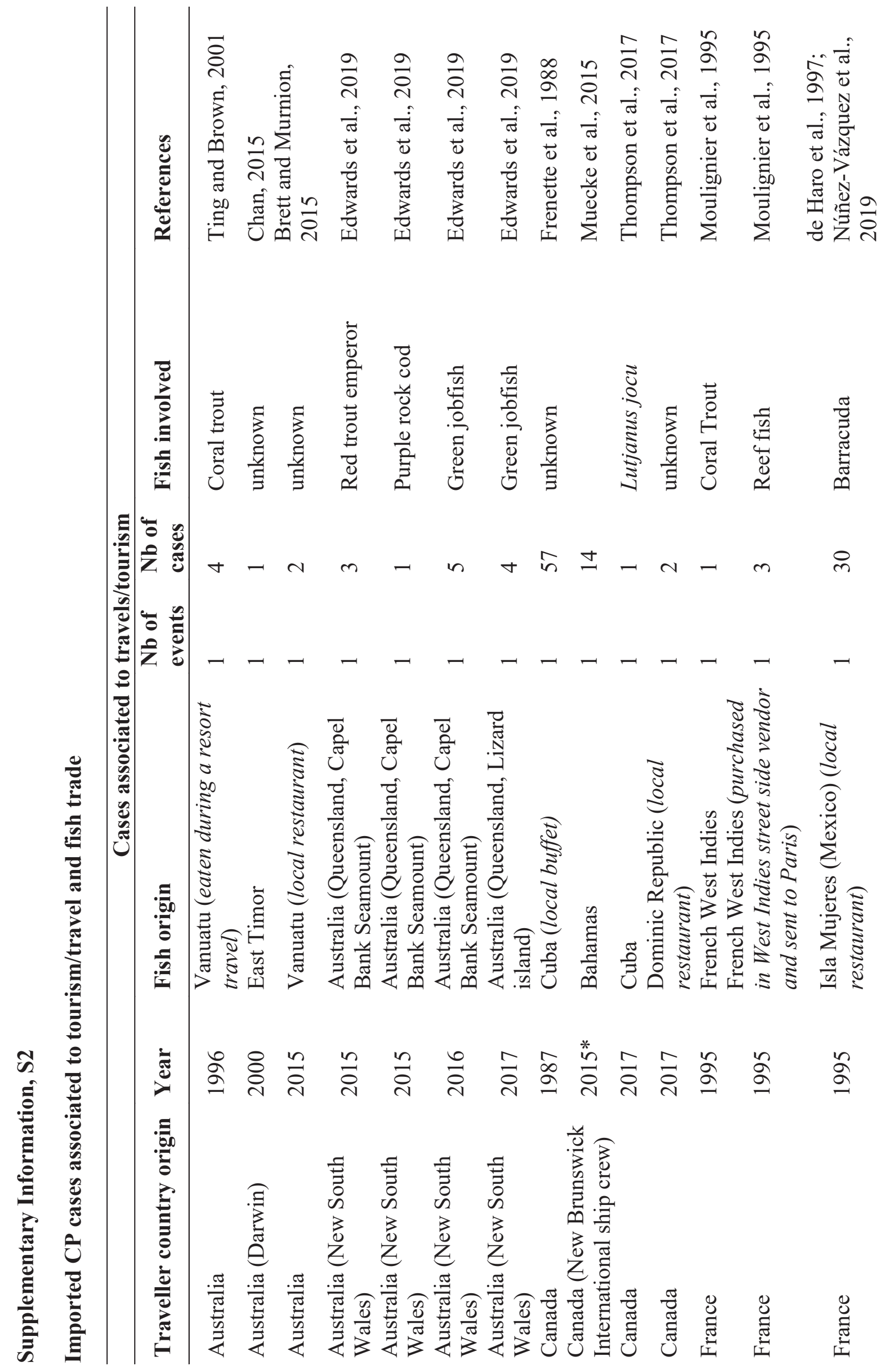




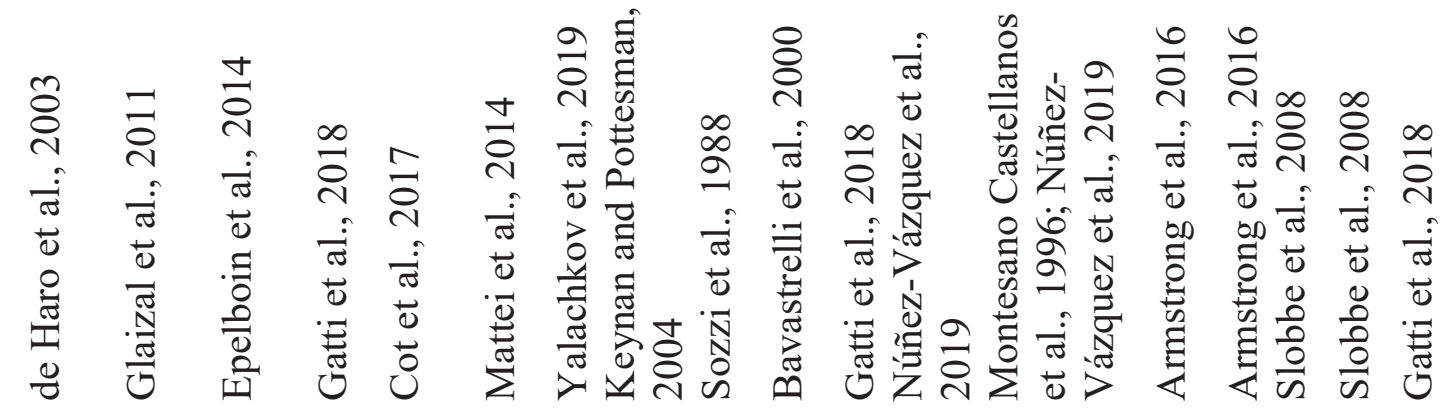
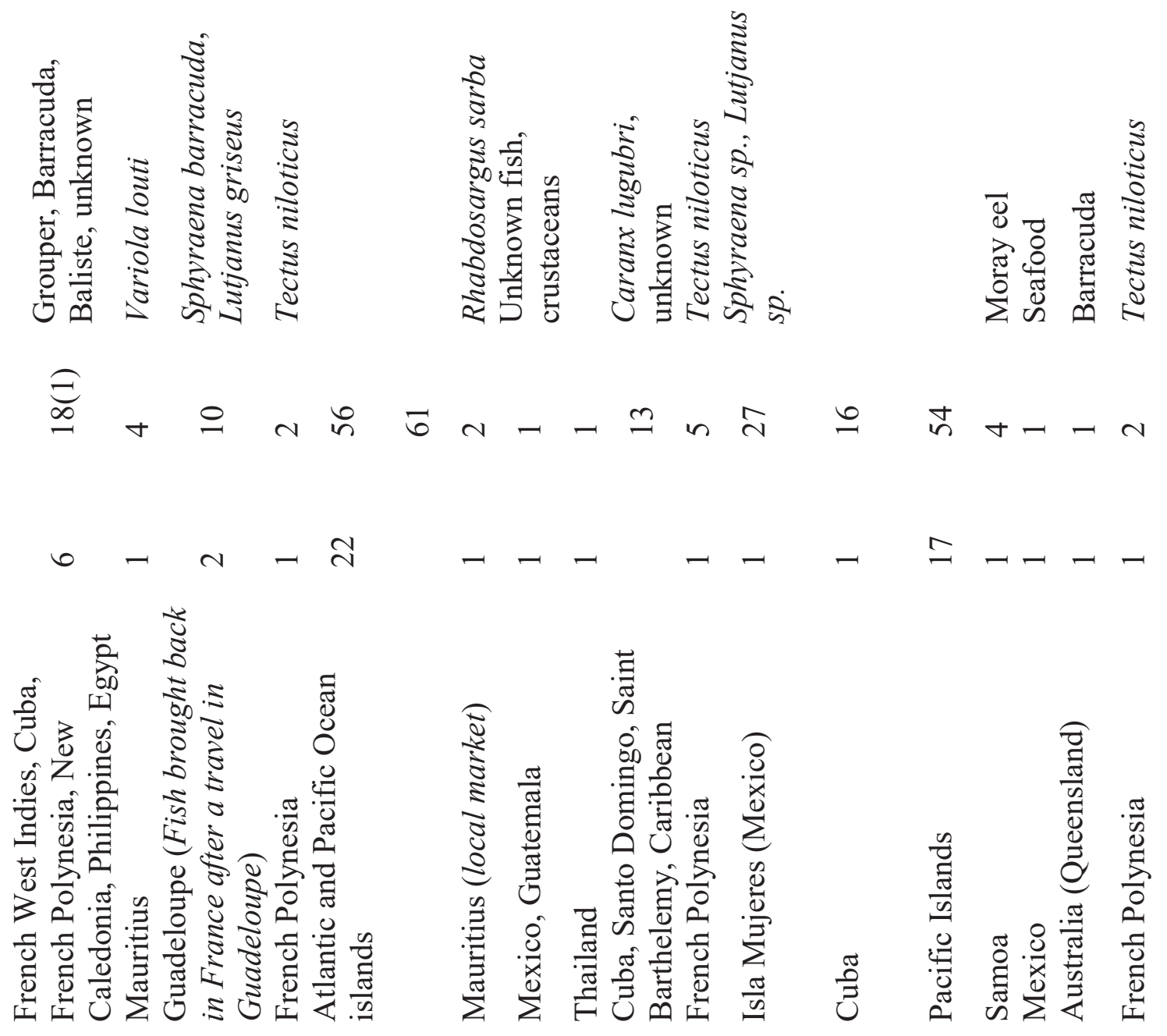

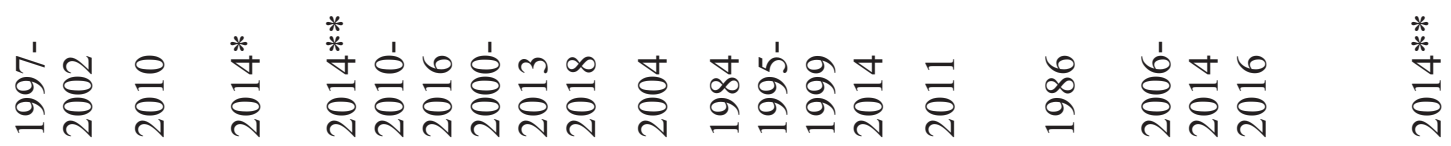

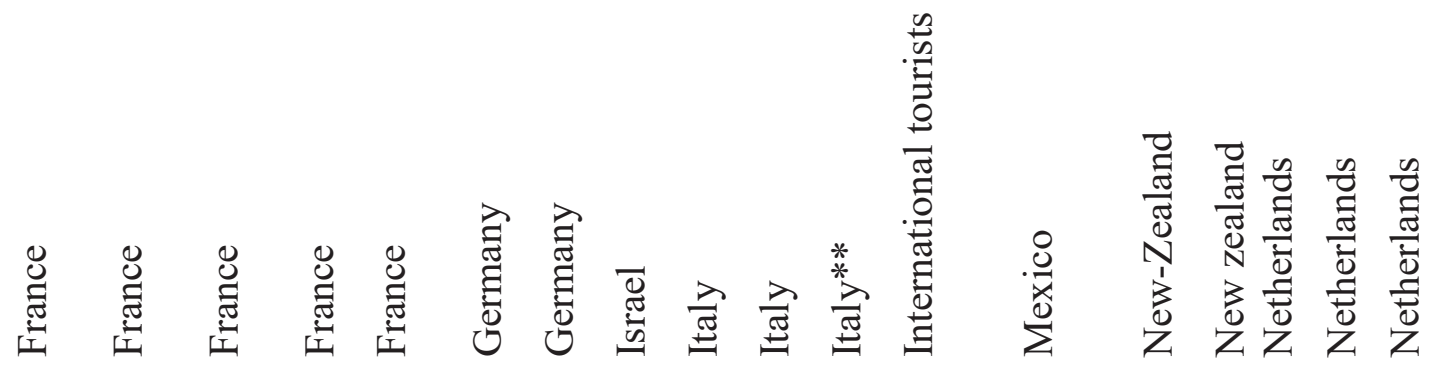




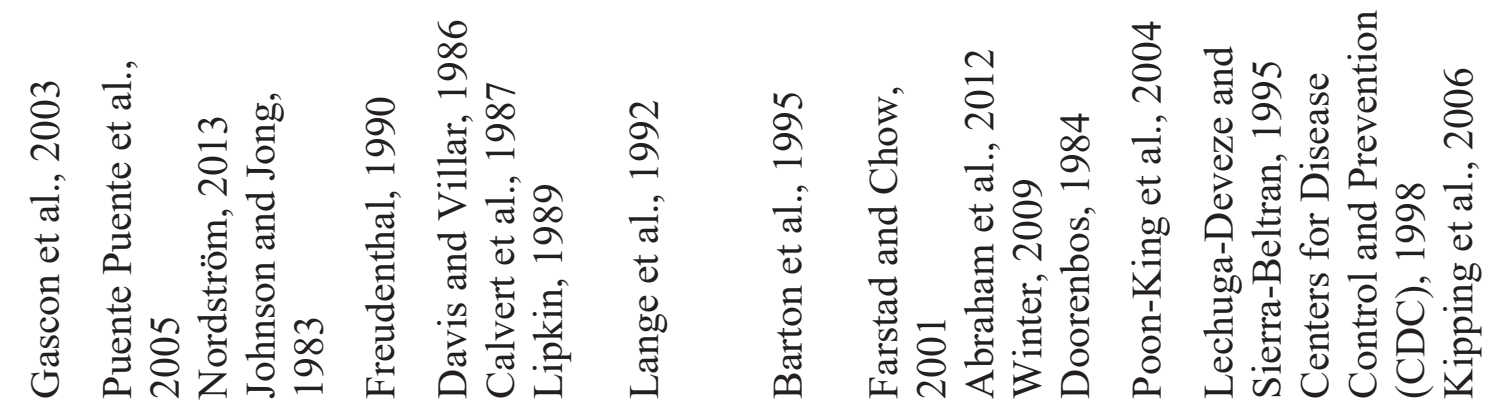

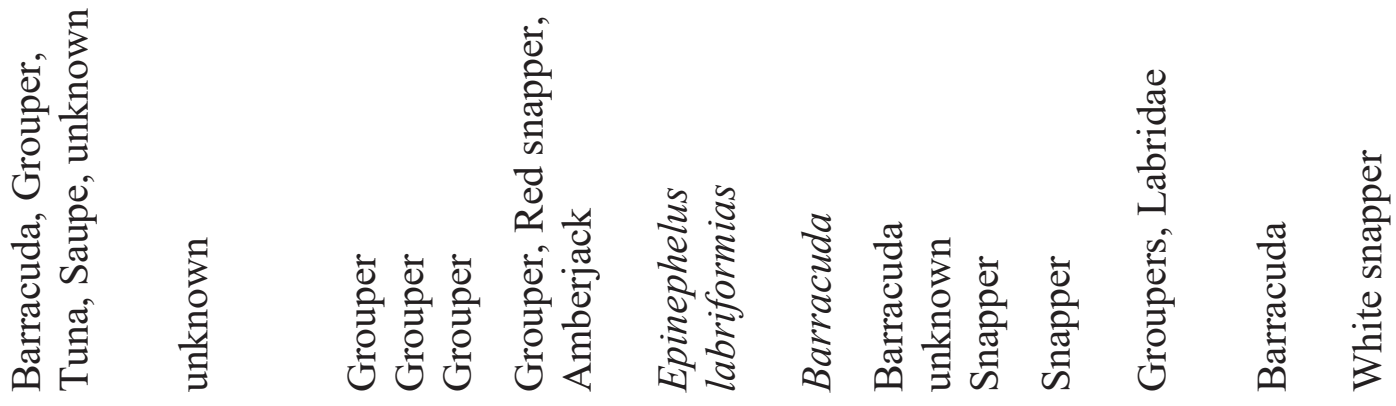

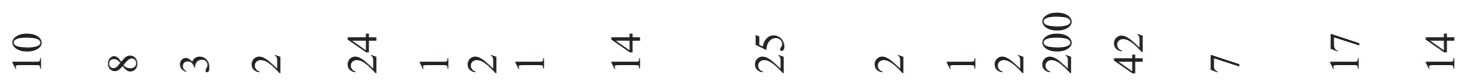

㕮

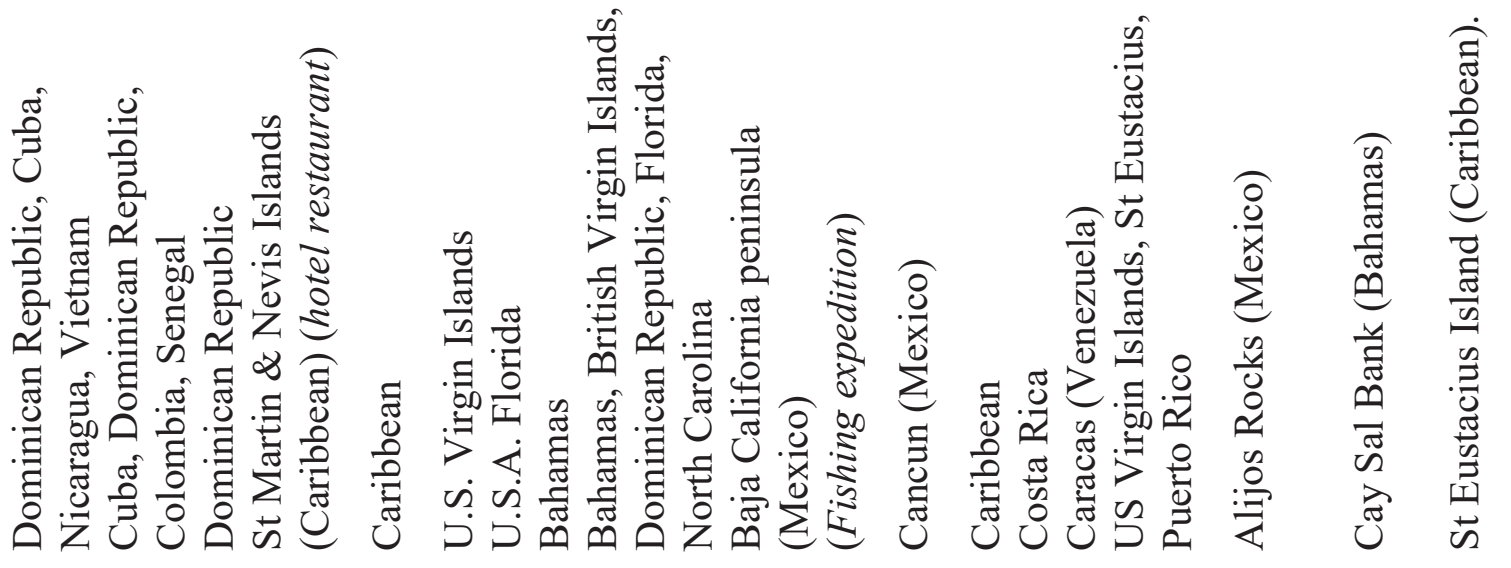

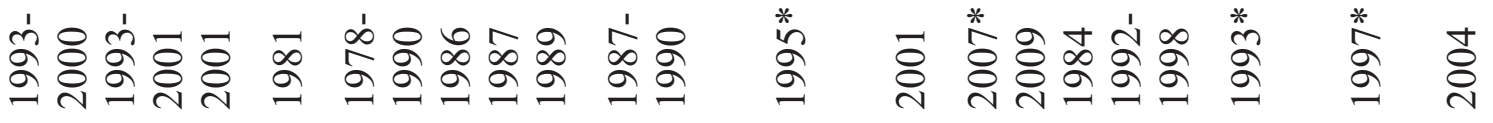

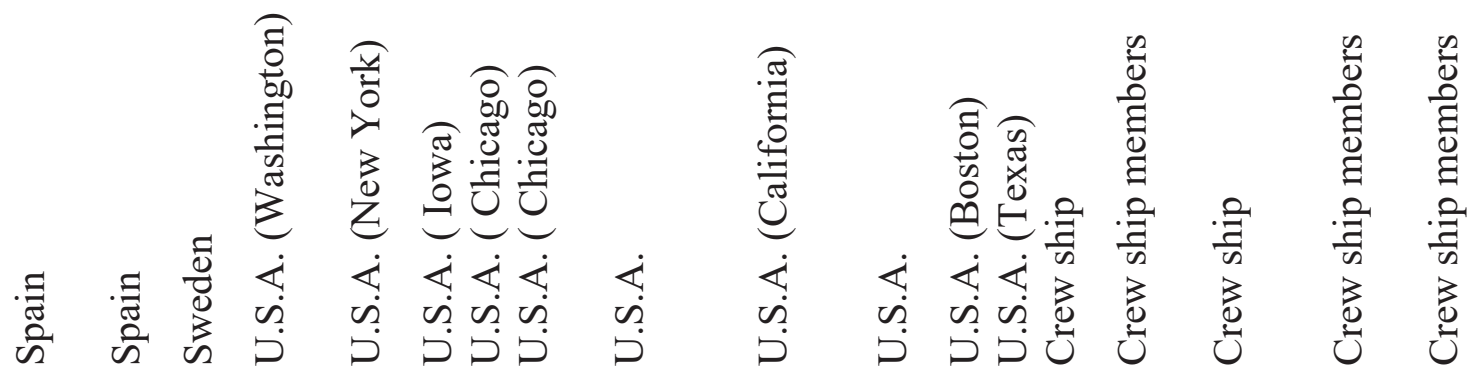




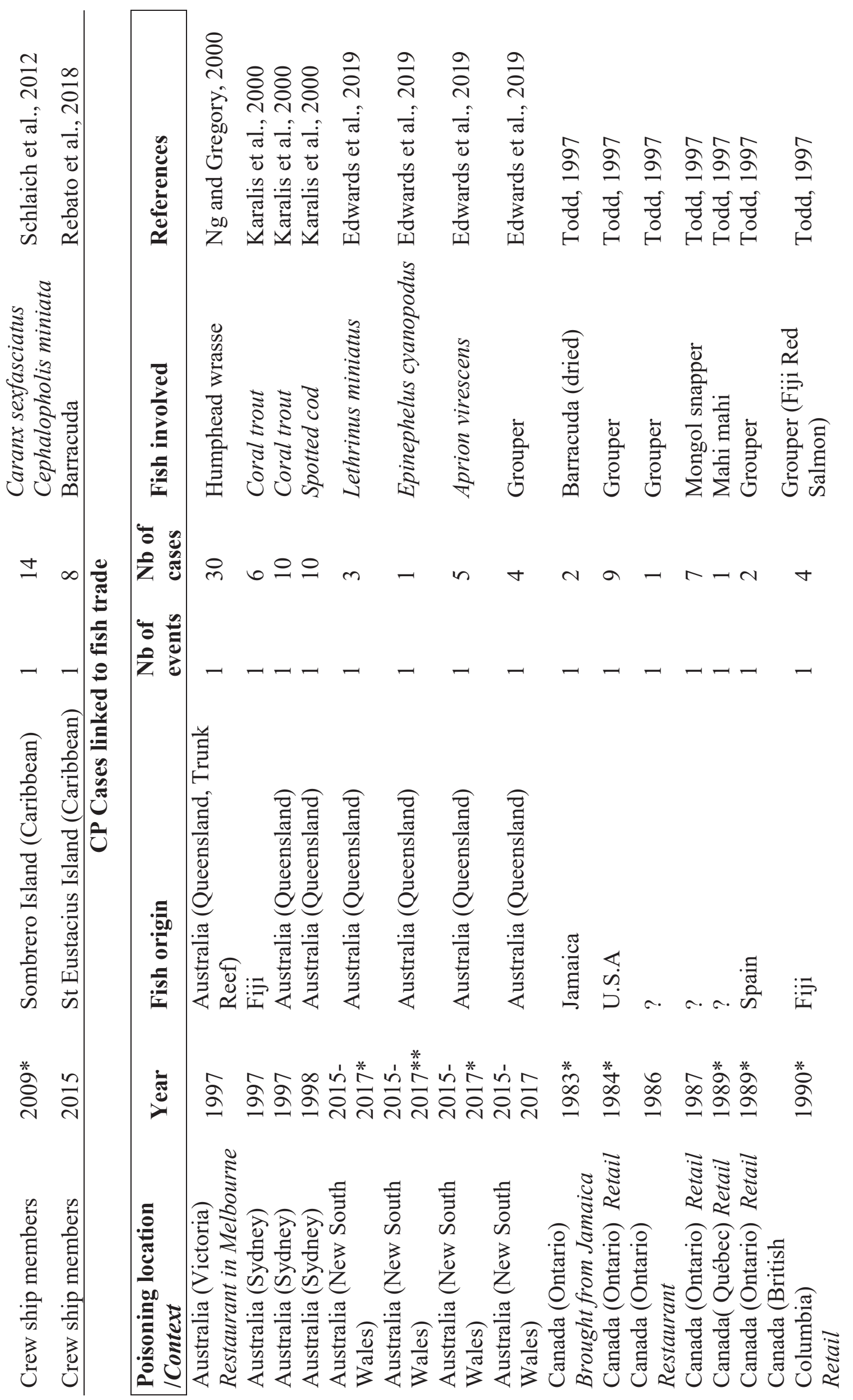




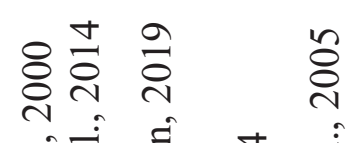

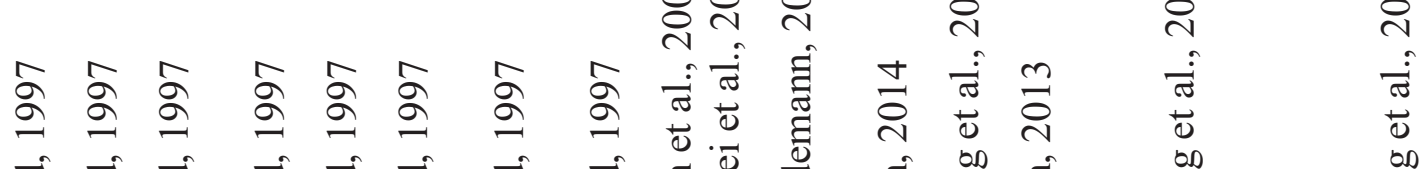

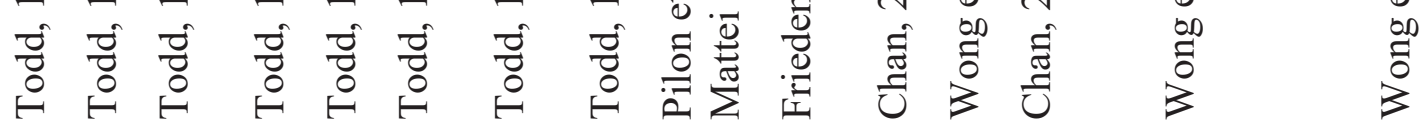

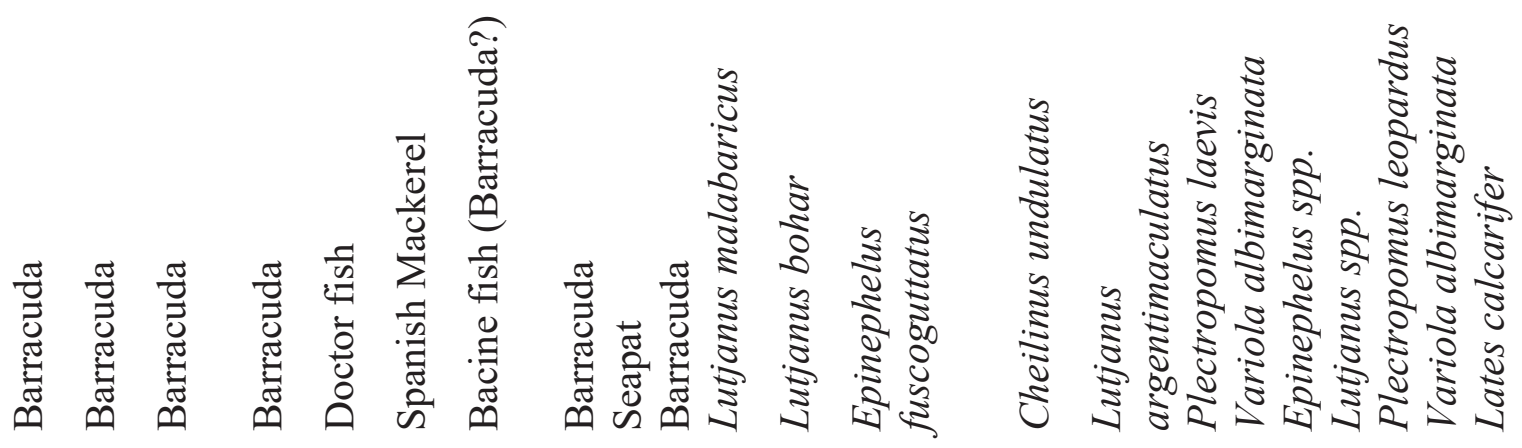

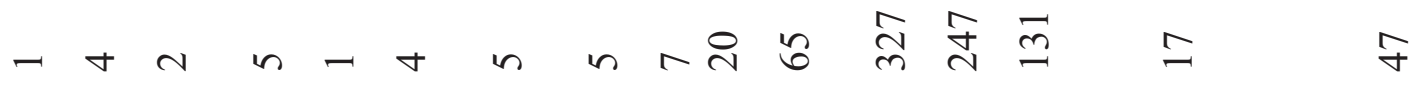

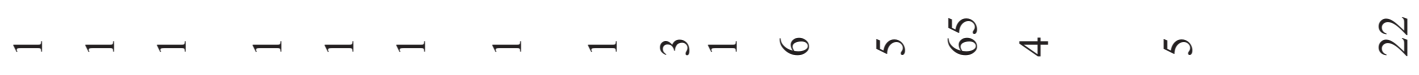

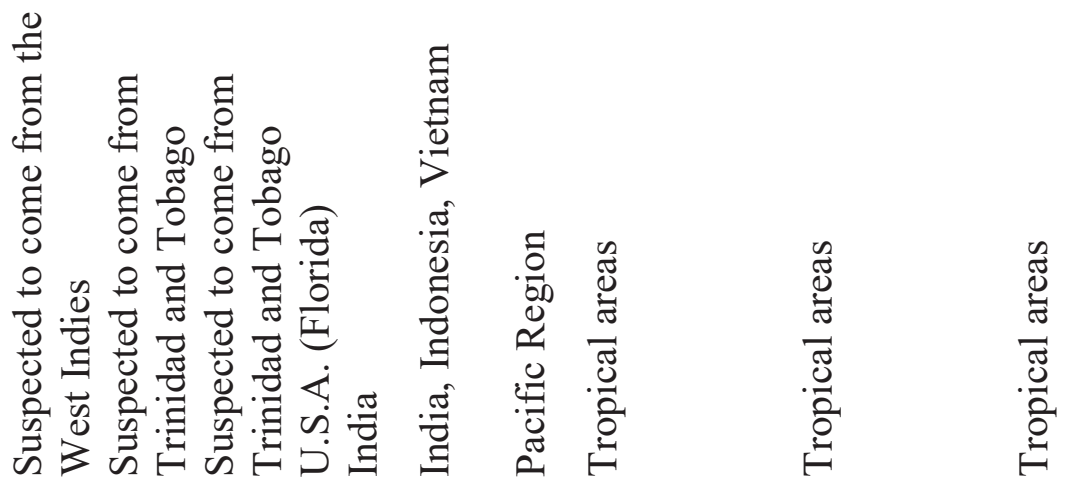

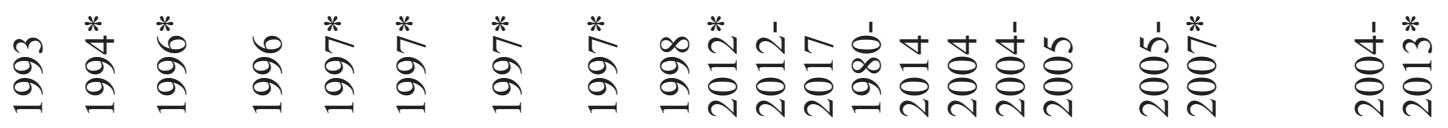

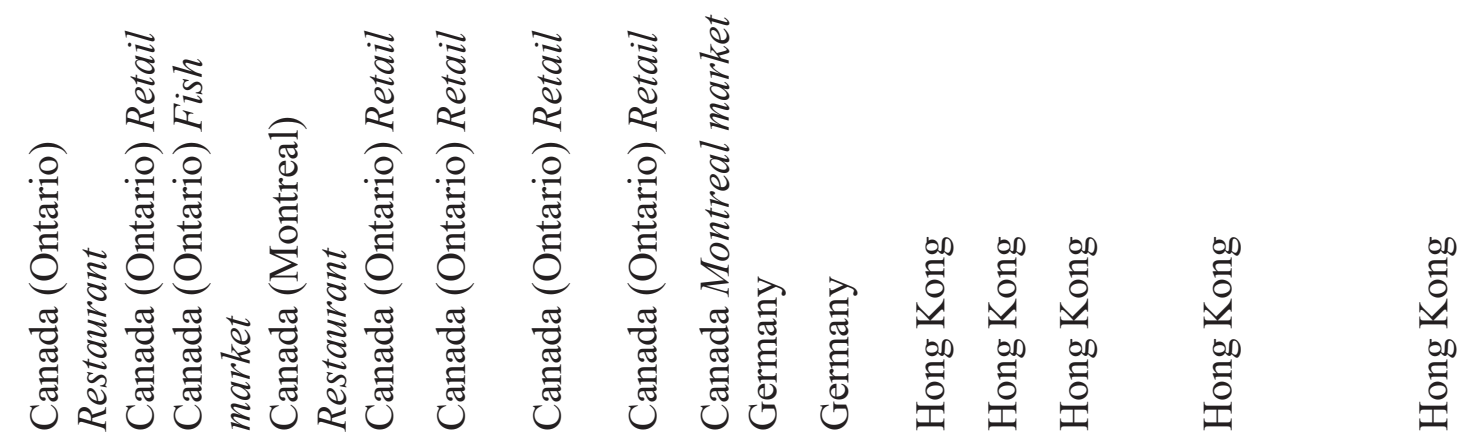




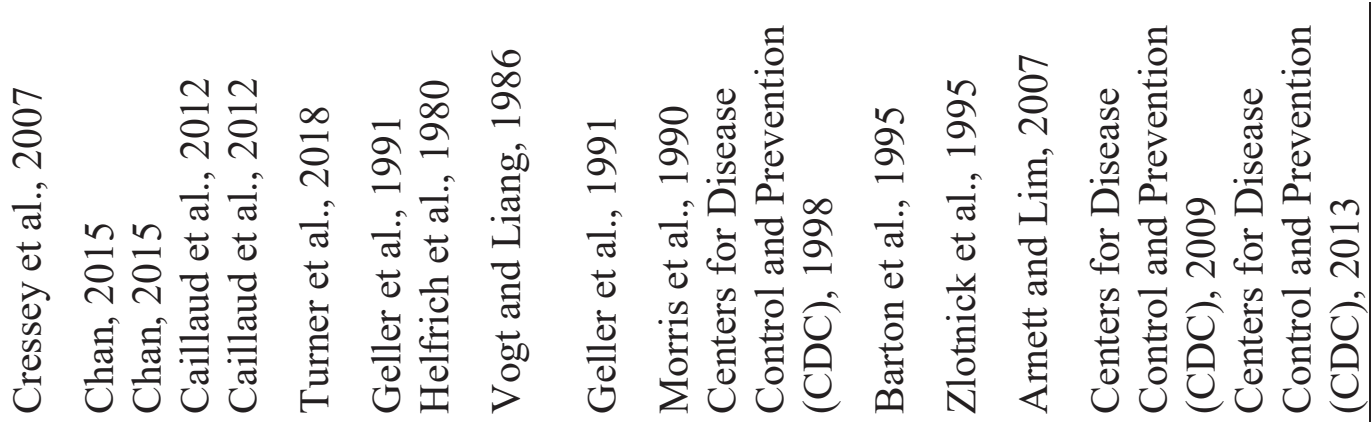

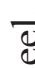

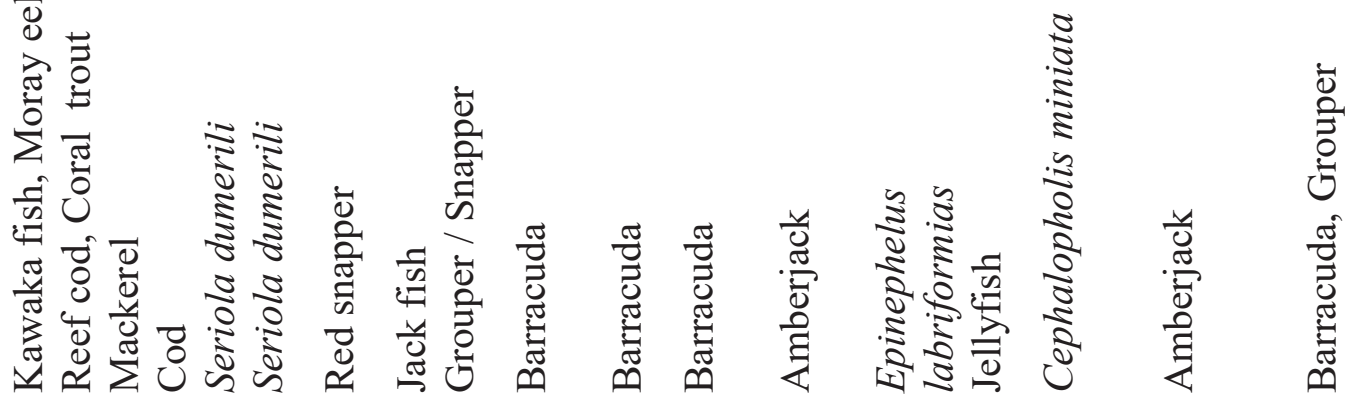

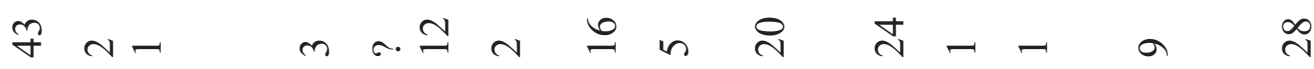

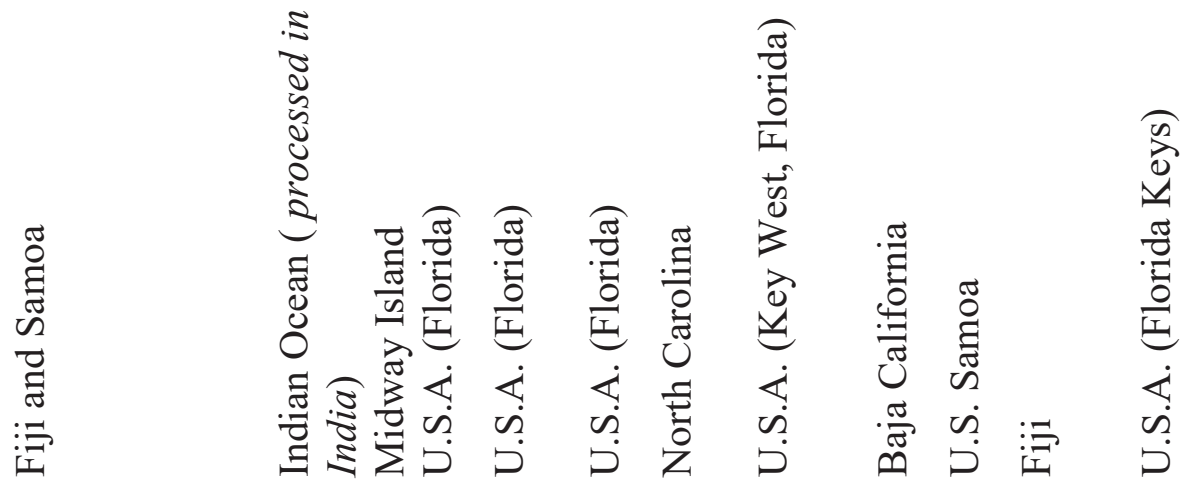

תే

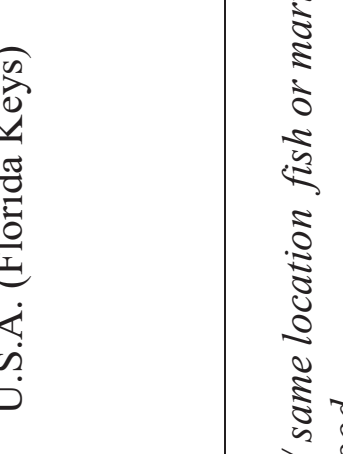

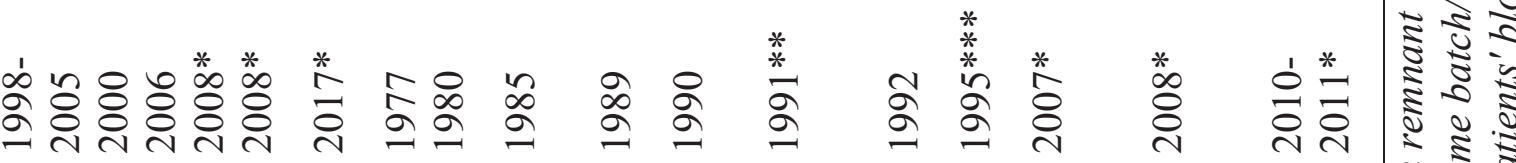

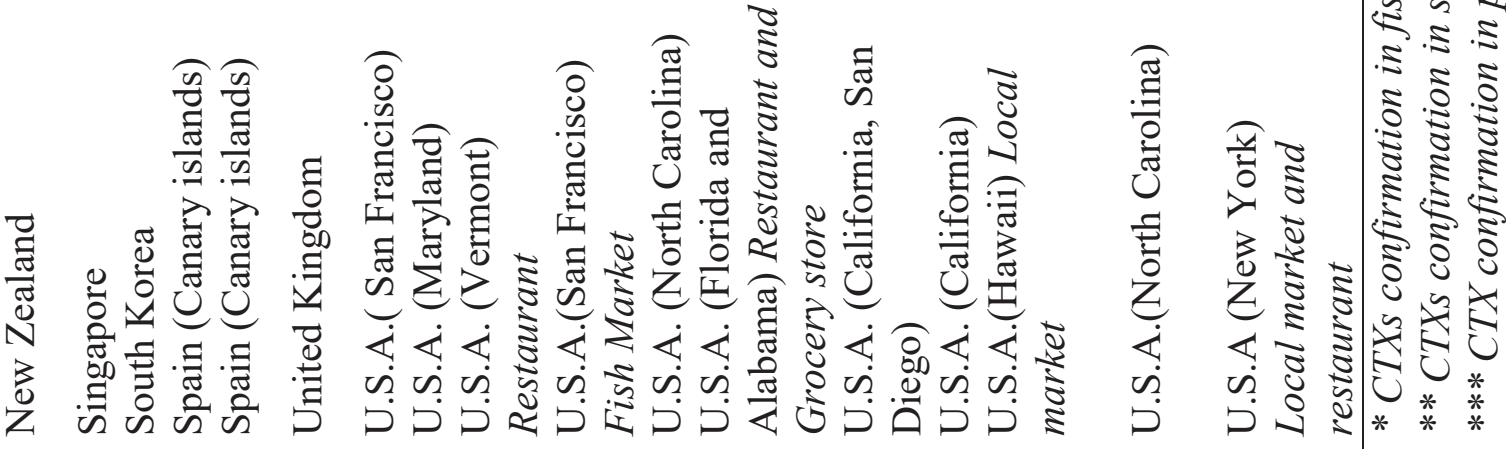




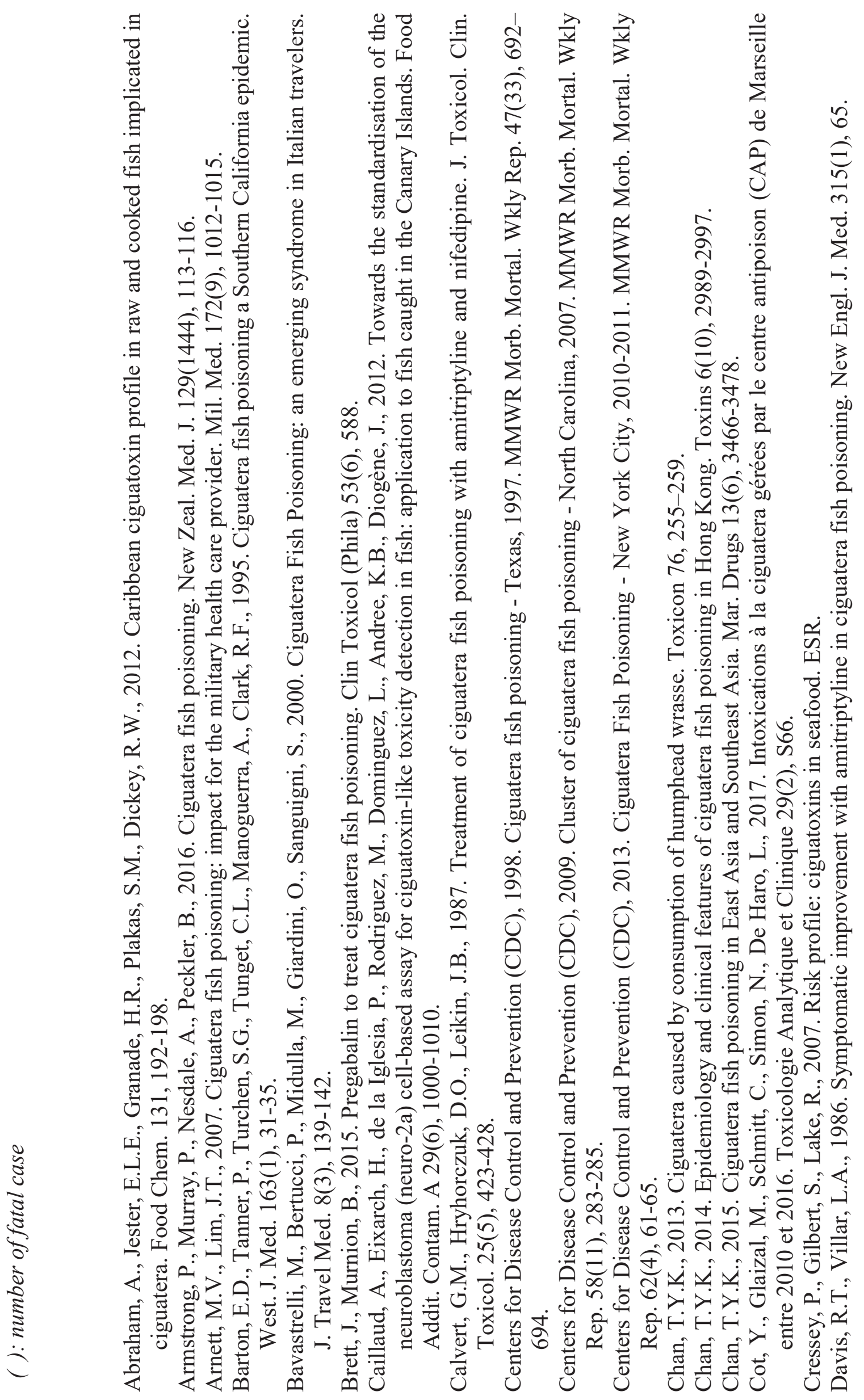




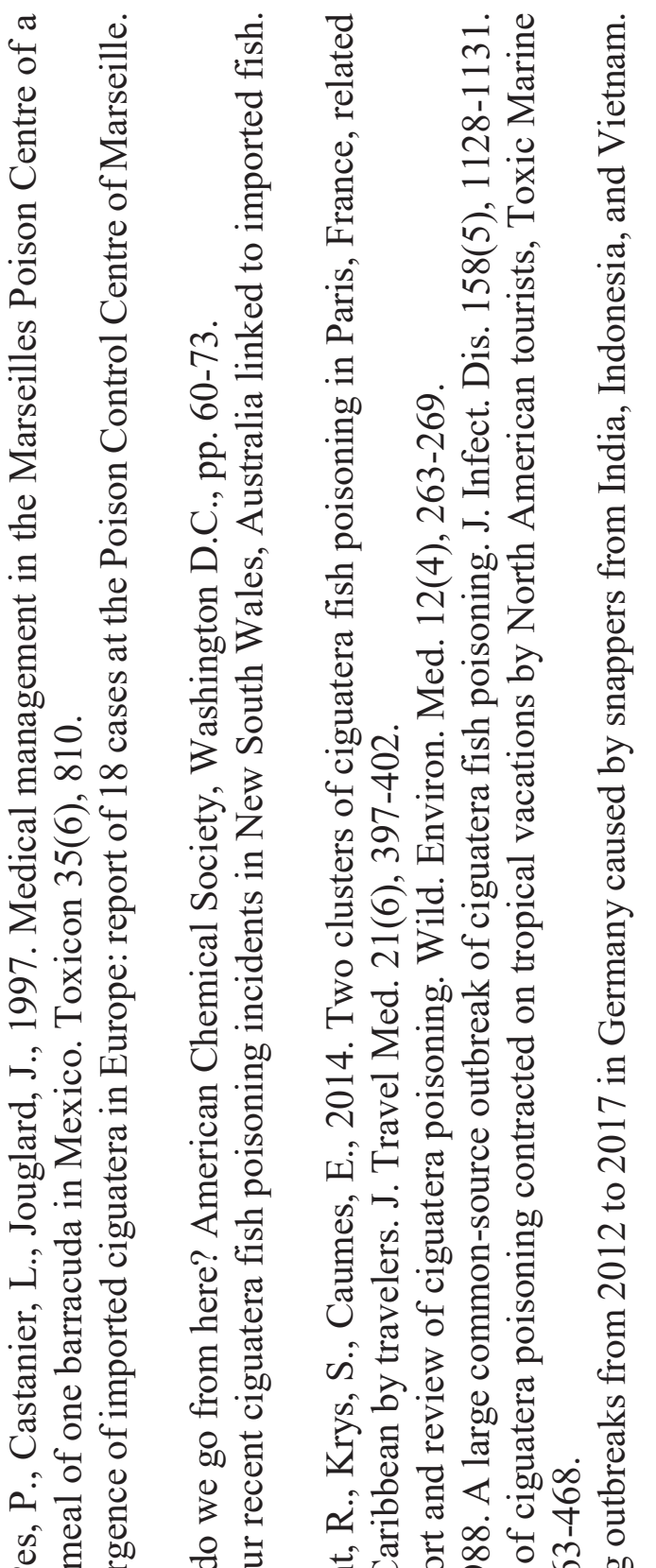

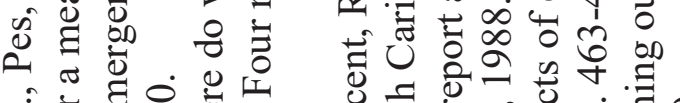

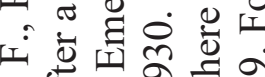

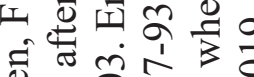

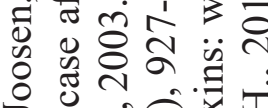

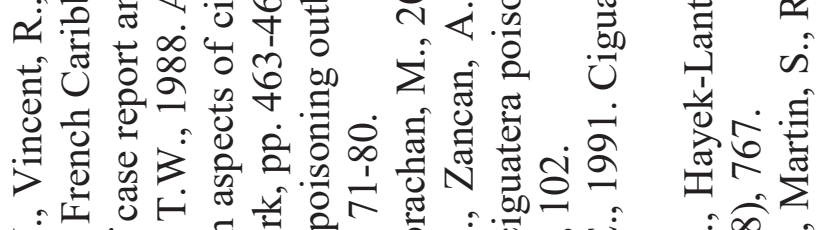

.

等

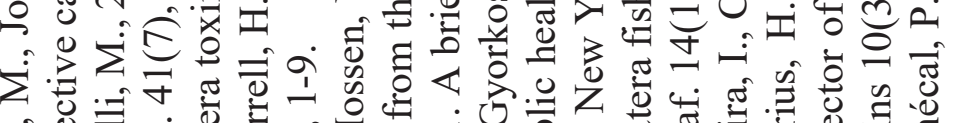

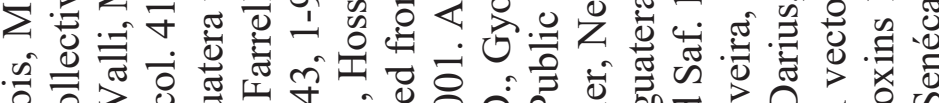

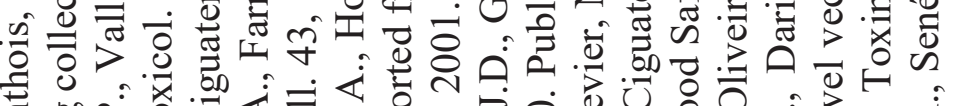

bi

䃞高

列高

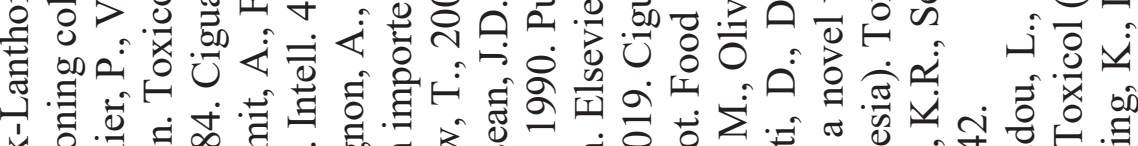

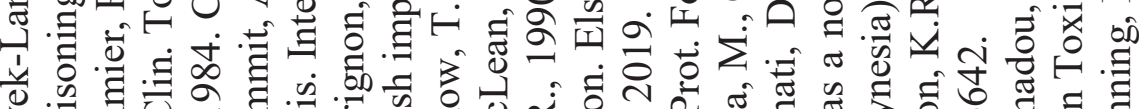

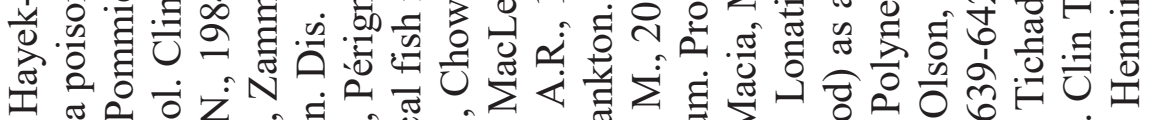

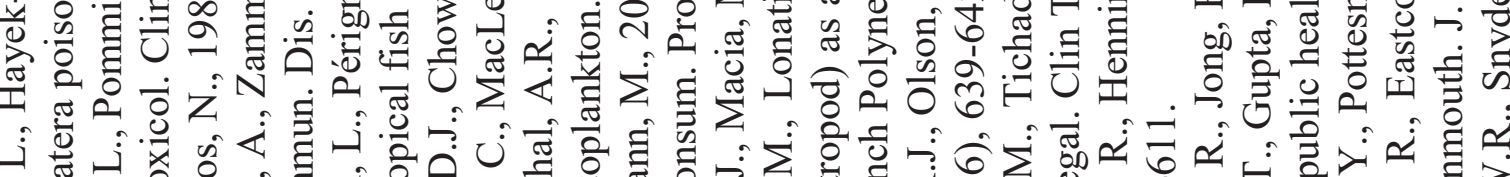

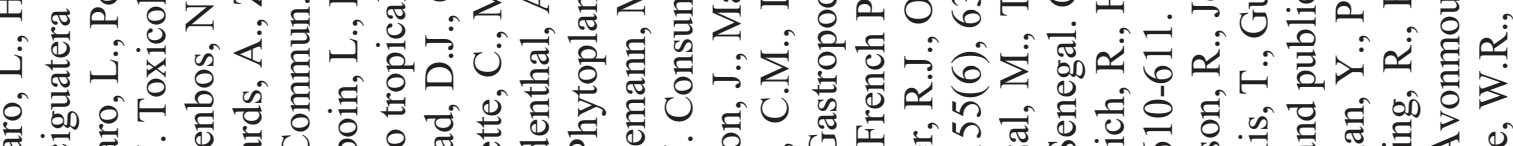

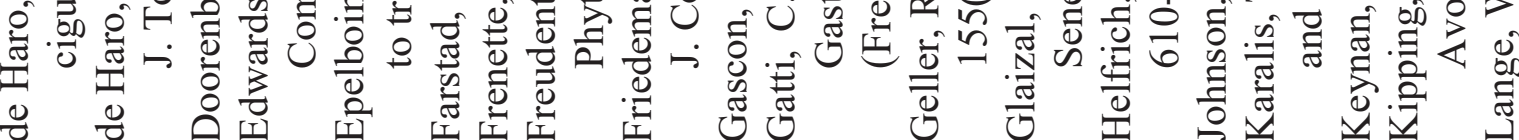




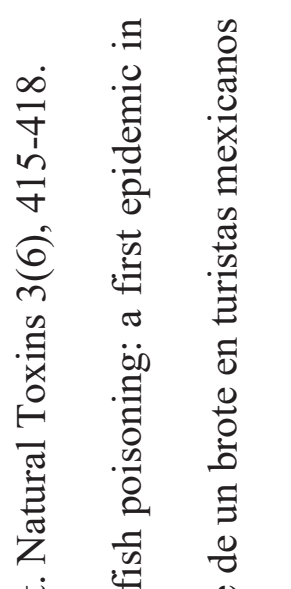

范宓

$0 \infty$

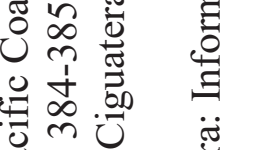

底的

数

पर

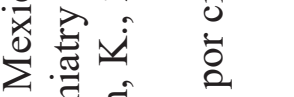

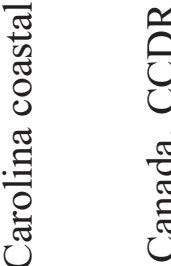

흉

छ)

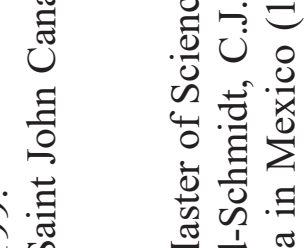

官完

जिए

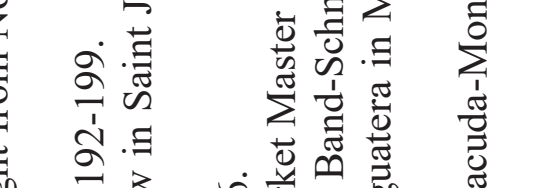

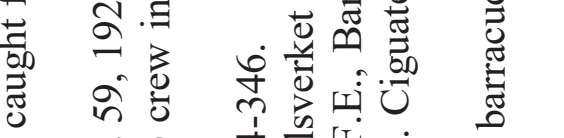

की

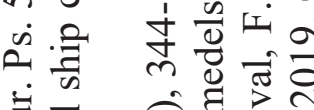

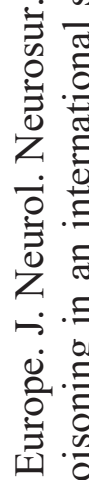

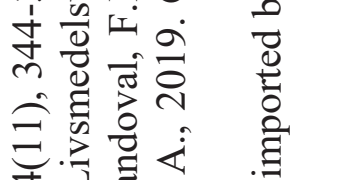

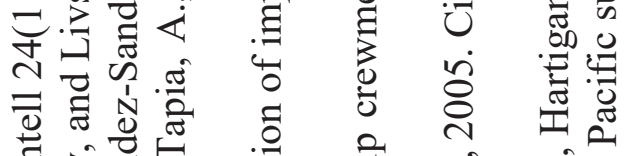

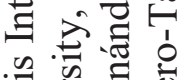

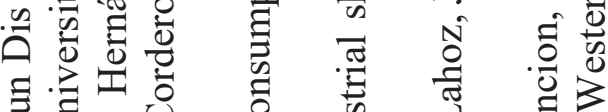

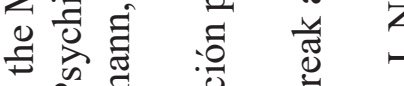

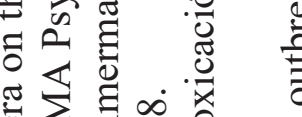

的手

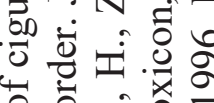

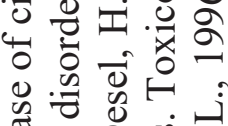

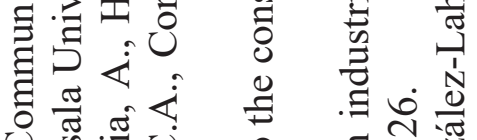

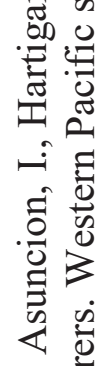

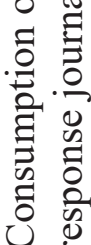

$\stackrel{\infty}{\circ}$

웡

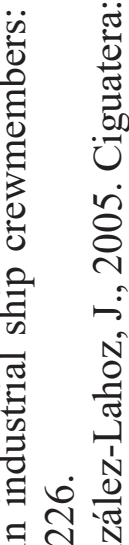

\.

$\overbrace{1}^{\circ}$

玹莺

일 옹 은

记

政

क力

ヨU

需

․ำ

.

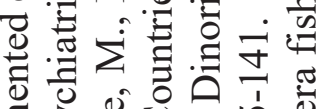

ฮैं

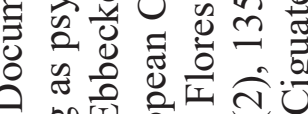

해을

然

믈

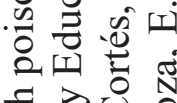

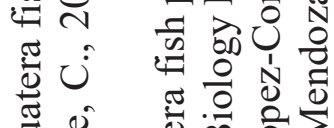

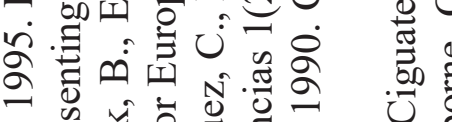

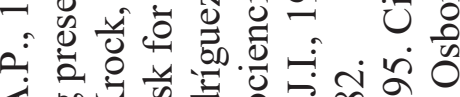

4 .

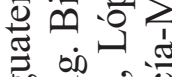

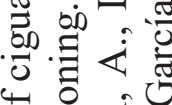

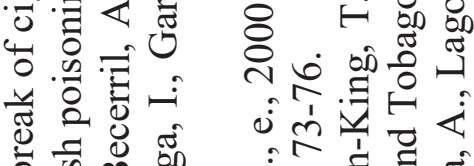

둥

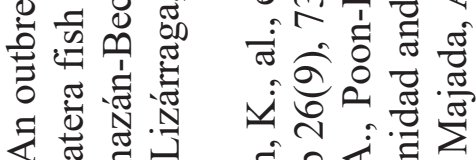

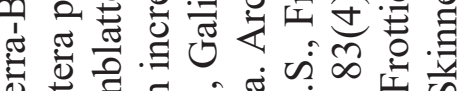

的爱

द议

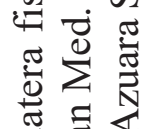

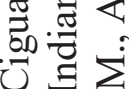

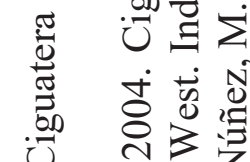

年

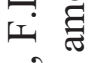

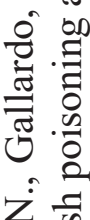

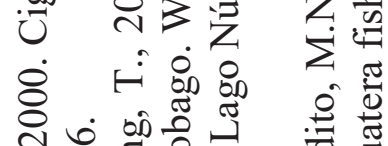

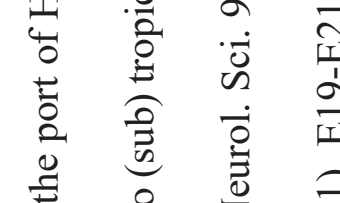

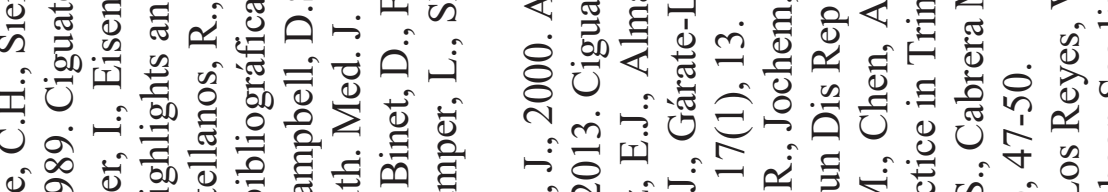

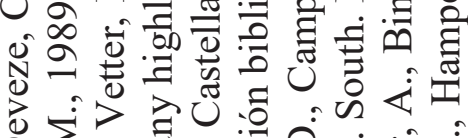

-

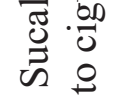

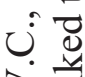

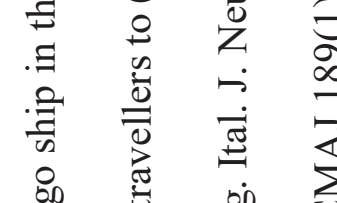

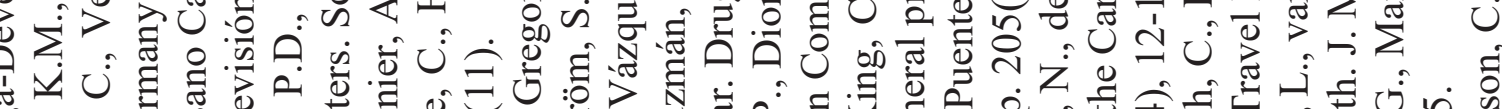

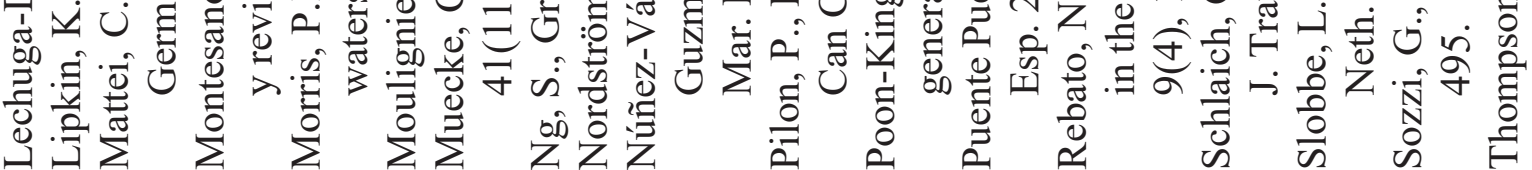




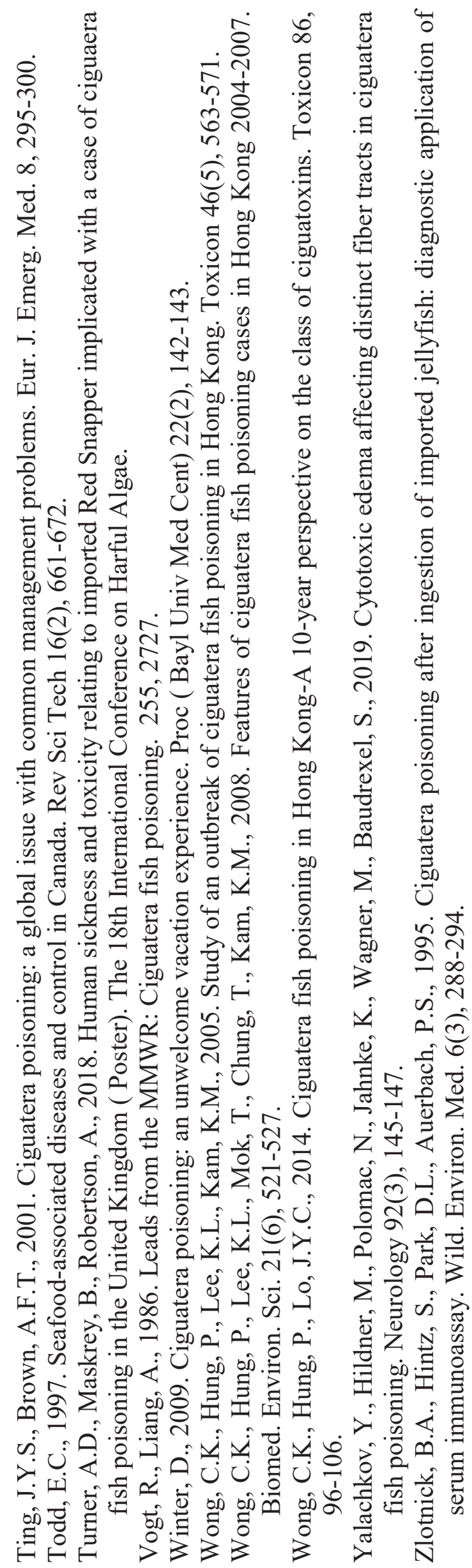




\section{Supplementary Information, S3}

\section{Ciguatera Poisoning (CP) in the Caribbean 1996-2006}

Ciguatera poisoning, prevalent throughout the Caribbean, has been inconsistently reported in many areas making it difficult to accurately analyze the spatial and temporal variation in $\mathrm{CP}$ occurrence. In general, $\mathrm{CP}$ in the Caribbean has been managed through traditional knowledge of local fishers and residents.

Below are summarized results from CP related surveys directed to points of contact in either health departments or fisheries organizations (or both) in 24 Caribbean island nations and territories and nine mainland countries bordering the Caribbean Sea (19962006) (Feldman and Tester, unpublished data) See Tester et al. (2009) and Tester et al. (2010) for details of the surveys and metholology. In addition to the surveys, a literature search was conducted to identify reported cases of CP in journals, records maintained by the Pan American Health Organization or the Caribbean Epidemiology Center, or other published accounts.

\section{$\underline{\text { Anguilla } \quad \text { Ciguatera presence: Yes }}$}

Information from the Fisheries Department in Anguilla indicated that citizens are very aware of the risks of ciguatera, although not concerned about them. No information is compiled by this department, but 25 or fewer cases of ciguatera per year have been reported in Caribbean Epidemiology Center (CAREC) reports. There was no response from the Health Department.

\section{Antigua and Barbuda $\quad$ Ciguatera presence: Yes}

The Health Department of Antigua and Barbuda (A\&B) compiled some information on ciguatera cases and was able to report the number of cases for each year between 1996 and 2006 (ranging from 170 in 2006 to 330 in 1998). While the Health Department considers $\mathrm{CP}$ one of its top five food-borne illnesses, central reporting of cases is voluntary. Numbers of cases from A\&B are also published in Pan American Health Organization (PAHO) and CAREC reports. The Fisheries Division of A\&B has issued advisories identifying certain areas where there is a high risk of catching ciguatoxic fish, and many species associated with ciguatera are restricted from export.

\section{$\underline{\text { Aruba }}$}

\section{Ciguatera presence: Yes}

The main hospital indicated that cases of ciguatera occur in Aruba, although records of specific numbers of cases were not accessible (an estimate was given of approximately 15 cases per year). The hospital issues press releases to advise the public about the risks when multiple cases are observed within a week. Local citizens are reportedly somewhat aware of and somewhat concerned about the risks. The cost of treating CP in the hospital emergency room was reported as \$200 (US) per person, and CP was ranked as one of the top 5 most severe food-borne illnesses in Aruba. No information was received from the Health Department, and the Fisheries Department does not collect information on CP. 
The Public Health Department of the Bahamas provided information on the number of cases of CP during the study period. More than 100 cases were reported each year, and the maximum number of cases reported in a single year was 263 in 2001. Since 1995, and sporadically in earlier years, there have also been cases reported by PAHO and CAREC. The Fisheries Department did not receive reports on cases of ciguatera but was able to respond to CP-related questions. Both departments noted both awareness and concern about CP among local citizens.

\section{$\underline{\text { Barbados }} \quad$ Ciguatera presence: Yes}

Representatives from the Fisheries Division and the Ministry of Health of Barbados did not answer the questionnaire, and both stated that CP does not occur on the island. However, 12 cases of CP were reported to CAREC in 2006.

\section{$\underline{\text { Belize }}$}

\section{Ciguatera presence: Yes}

According to the Belize Health Department, reporting of CP is mandatory, although the Department had no cases in its records for the study period, from 1996 through 2006. Data reported annually to CAREC since the 1980s included up to $11 \mathrm{CP}$ cases per year between 1992 and 1997, as well as 4 cases in 2003. The Health Department did not rank CP as one of the top 10 most severe food-borne diseases in Belize and commented that citizens were neither very aware of nor concerned about the risks of CP. The Fisheries Department did not return the questionnaire and indicated it could find no recorded information on CP in Belize.

\section{$\underline{\text { British Virgin Islands }}$}

\section{Ciguatera presence: Yes}

The Ministry of Health and Social Development of the British Virgin Islands compiles information on cases of $\mathrm{CP}$, although reporting is voluntary. The Ministry had data available on the number of CP cases for 2000 to 2004, ranging from 6 to 70 per year. Cases from the $\mathrm{BVI}$ are also reported in CAREC and PAHO reports. In fact, annual data reported by CAREC for 1980 through 2005 indicated that CP was diagnosed annually, with 8 to 103 cases per year. A representative of the Ministry indicated she thought citizens are very aware of and somewhat concerned about exposure to CP. The Fisheries Department did not respond to requests for information.

\section{$\underline{\text { Cayman Islands }}$}

\section{Ciguatera presence: Yes}

Reporting of CP is mandatory in the Cayman Islands. The Health Department provided data on CP cases for every week during the study period. A few cases were reported most years, with 36 cases reported in 2002. The maximum number of CP cases reported to CAREC in a year was 59 in 1985. The Health Department considers CP to be one of the top 5 food-borne illnesses and will issue advisories about the risk of eating large fish from reefs when clusters of CP cases occur. The Health Department has some data on where ciguatoxic fish have been caught most commonly. The Fisheries Department does not compile information on CP but a representative did comment that native citizens are very aware of the risks of $\mathrm{CP}$, while newer residents are not. The Fisheries Department also commented that most fishermen make choices intended to reduce the chance of distributing fish they consider to have a high risk of being ciguatoxic. 
According to the Colombia National Institute of Health, there is currently no exclusive surveillance system for $\mathrm{CP}$, so there were no records of cases during the study period. However, 14 cases were reported in 2007. Also, it was noted that there is some local knowledge by the native population of locations and seasons favorable to $\mathrm{CP}$. The Fisheries Department did not return the questionnaire because it does not collect information on $\mathrm{CP}$.

\section{Costa Rica}

\section{Ciguatera presence: No}

The respondent from the Costa Rican Institute of Fisheries and Agriculture had never seen or heard about cases of CP in Costa Rica in 21 years of working for the Institute. The Ministry of Health's Epidemiological Surveillance Department had also never heard of any cases being reported in Costa Rica, and there have been no reported cases in the literature.

\section{$\underline{\text { Cuba }}$}

\section{Ciguatera presence: Yes}

There are restrictions on the types of fish or the size of fish that can be consumed in Cuba due to the risk of ciguatera. The Ministry of Public Health maintains a record of CP cases in Cuba and reporting to this registry is mandatory. The Center for Fisheries Investigations filled out parts of the questionnaire. Specific numbers of cases were not provided by respondents, but the Epidemiological Surveillance Department of the Epidemiological Section published data online from 1997 through 2006 (during which time there were between 19 and 89 cases per year). The respondent from the Center for Fisheries Investigations reports that local citizens and fishermen are somewhat aware of and slightly to somewhat concerned about the potential risk of contracting $\mathrm{CP}$.

\section{Dominica}

\section{Ciguatera presence: Possible}

The respondent from the Ministry of Health's Health Information Unit did not have information on $\mathrm{CP}$, and a respondent from the Fisheries Division indicated there is no $\mathrm{CP}$ in Dominica and did not complete the questionnaire. The only reports of CP in Dominica came from a 1984 study that reported two cases of CP caused by triggerfish, but no other cases have been reported in the literature to date. Data collected by CAREC since 1980 do not include any reports of CP in Dominica.

\section{Dominican Republic}

\section{Ciguatera presence: Yes}

The Head Office of Epidemiology collects information on CP cases, although reporting is voluntary. Cases were reported during the entire study period and ranged between 27 and 63 per year. There have been advisories by the Fish and Wildlife office warning people not to eat certain types of fish with the potential to cause CP between the months of May and August. According to the Dominican Fisheries and Aquaculture Council, there are also bans on the capture or marketing of certain species known to be ciguatoxic. Government officials report some awareness among citizens and local fishermen of CP. 
Neither the Health Department nor the Fisheries Department compiles information on CP cases in Grenada. The only report of CP in Grenada was from a Fisheries Department officer whose family became ill with CP-like symptoms after eating a fish from the Carangidae family; species implicated as the probable source of CP in other parts of the Caribbean. The Fisheries Department indicated that citizens are not very aware of or concerned about the risks of CP.

\section{Guadeloupe}

\section{Ciguatera presence: Yes}

Surveillance for CP was set up in 2004, and there were between 7 and 20 cases per year reported from 2004 through 2006. Detailed information about CP cases, when reported voluntarily, is collected by the Sanitary Surveillance Institute of France. An official responsible for Food Hygiene thought that people who get $\mathrm{CP}$ often do not go to a doctor. Although exact figures were unavailable, a few CP cases were also reported in St. Martin and Saint Barthélemy, which were administratively part of Guadeloupe until 2007. Cases of CP have been reported for all three islands in the local newspapers, as well as in the scientific literature. The questionnaire was not completed by fisheries officials.

Guatemala

\section{Ciguatera presence: No}

The Ministry of Public Health did not provide information because a representative stated that there is no CP in Guatemala. The Fishery and Aquaculture Management Unit in Guatemala did not have information on $\mathrm{CP}$, although it does have a red tide monitoring program on the Pacific coast. A representative of this unit suggested that information about CP usually is not reported by fishermen because of the harm it could cause to fish sales. It was also noted that fishermen are not very aware of the risks of CP. No cases of CP in Guatemala were found in published reports.

\section{$\underline{\text { Haiti }}$}

\section{Ciguatera presence: Yes}

Despite multiple attempts, we were unable to establish a contact in either the Health or Fisheries Department in Haiti. Cases of CP have been reported in the literature, although they occurred outside of the study period.

\section{$\underline{\text { Honduras }} \quad$ Ciguatera presence: Possible}

According to the Honduran Fisheries and Aquaculture Network, Honduras does not collect information on CP because there have been no cases reported. The only suspected cases of CP were recent, in May 2008. However, there was no confirmation that the seafood-borne illnesses resembling $\mathrm{CP}$ were in fact $\mathrm{CP}$. Fishermen are aware that barracuda can cause illness, although most are not familiar with CP. It was reported that both fishermen and local citizens are slightly concerned about CP. The Health Department did not respond to the questionnaire because it received no official reports of $\mathrm{CP}$.

\section{$\underline{\text { Jamaica }} \quad$ Ciguatera presence: Yes}

The Ministry of Health has some records of CP cases, but reporting is voluntary. Numbers of cases were reported for most years during the study period and ranged from 5 to 22 per year. Cases are also reported to CAREC. In 2006, CAREC recorded 126 cases of CP, although only 10 were reported by the individual responding to the questionnaire. The Ministry of 
Health has issued advisories about consuming fish that may cause CP. The Fisheries Department did not return the questionnaire.

\section{Martinique $\quad$ Ciguatera presence: Yes}

Information on CP is gathered by the Sanitary Surveillance Institute of France. During the study period, between 8 and 36 cases per year were reported during 5 different years. However, reporting is voluntary. The questionnaire was not completed by fisheries officials. There is reportedly some awareness and slight concern about the risk of $\mathrm{CP}$ among citizens. Also, PAHO reported data from some years, including 46 cases in 1996.

\section{$\underline{\text { Mexico }} \quad$ Ciguatera presence: Yes}

Cases of $\mathrm{CP}$ were reported by respondents from the Department of Fishery Production as occurring in the State of Quintana Roo. Between 0 and 13 cases per year were reported from 1997 through 2002. There are some reports of cases from the Pacific coast of Mexico (Baja) and southern California, although these occurred before the study period. No representatives from the Health Secretariat returned a completed questionnaire.

\section{$\underline{\text { Montserrat }} \quad$ Ciguatera presence: Yes}

The Montserrat Health Department collects data on the number of cases of CP. It reports an average of 17 cases per year (more than 200 cases from 1999 through 2006); reporting is voluntary. The respondent ranked CP as one of the top 5 most severe food-borne illnesses in the country. The Fisheries Department does not compile comprehensive data on CP cases but does receive some reports from fishermen and residents. The respondents indicated that citizens and fishermen are very aware of the risk of CP. Numbers of cases are also reported by CAREC and were slightly higher than those reported by the Health Department.

\section{$\underline{\text { Netherlands Antilles }}$}

\section{Ciguatera presence: Yes}

The Inspectorate of Public Health reported that information on CP is currently not collected by agencies in the Netherlands Antilles due to the lack of a monitoring program. Although numbers of cases in the Netherlands Antilles are unknown, according to a respondent from the Fisheries Department, it is recognized that CP occurs frequently in certain places. Because of this, eating certain species (such as barracuda) or certain parts of fish (such as the head and liver) is avoided, as is fishing in certain waters known to have toxic fish. The contacts at the Inspectorate of Public Health and the Fisheries Department had different opinions about awareness of CP risks by fishermen and local citizens, including citizens being unaware or somewhat aware and fishermen being very aware.

\section{Nicaragua $\quad$ Ciguatera presence: No}

No questionnaires were returned, but staff from the Ministry of Health reported no cases of $\mathrm{CP}$ had occurred in Nicaragua. There have not been any cases of CP in Nicaragua reported in the literature. 
Contacts from both the Health Department and the Fisheries Department reported they had not heard of any cases of $\mathrm{CP}$ and did not return the questionnaire. One contact mentioned that he and his colleagues had been catching and eating all types of fish in Panama for over 30 years and had never been sick or ever heard of someone in Panama getting sick from CP. There are no reports of CP in Panama in the literature.

$\underline{\text { Puerto Rico }}$

Ciguatera presence: Yes

Reporting of CP has been mandatory in Puerto Rico for over 20 years. There were between 6 and 20 cases of CP reported annually during the study period. Fishing regulations prohibit taking or selling of certain CP-related species. Most respondents indicated that fishermen and citizens are very aware or somewhat aware of the risk of CP, but only somewhat or slightly concerned about it. According to a representative from Puerto Rico Sea Grant, in 1998, Dr. Thomas Tosteson estimated the economic impact of ciguatera in Puerto Rico could be as high as $\$ 8-10$ million per year.

$\underline{\text { St. Kitts and Nevis }}$

Ciguatera presence: Yes

According to the Department of Fisheries, while no surveillance program exists for $\mathrm{CP}, \mathrm{CP}$ does occur in St. Kitts and Nevis. The respondent indicated that citizens are very aware of the risk of CP. The Department of Health did not respond because it does not collect information on CP. CAREC reports a total of 5 cases of CP between 1996 and 2006.

\section{St. Lucia}

\section{Ciguatera presence: No}

The Department of Fisheries reported that information on CP is not collected in St. Lucia, is unaware of any cases of ciguatera identified there, and did not complete the questionnaire. There are also no reports of CP in St. Lucia in the literature, including in the CAREC database. The Department of Health did not respond because it does not collect information on CP.

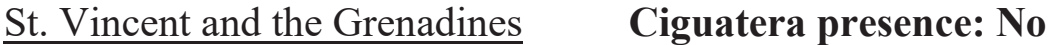

The Fisheries Department indicated that there have been no cases of CP and that citizens and fishermen are not very aware of or concerned about the risk of CP. There have also been no reports in the literature or in the CAREC database. The Health Department did not respond because it does not collect information on CP.

\section{$\underline{\text { Trinidad and Tobago } \quad \text { Ciguatera presence: Yes }}$}

The Ministry of Health reports that there have been no cases of $\mathrm{CP}$ and that citizens are not aware of or concerned about the risk of CP. In addition, there have been no $\mathrm{CP}$ reports in the peer-reviewed literature. However, CAREC reports that there have been six cases of CP in Trinidad and Tobago since 1999, with no cases in prior years. Representatives of the Fisheries Department did not respond to requests for information.

$\underline{\text { Turks and Caicos Islands }}$

Ciguatera presence: Yes

The Health Department did not return the questionnaire. Very little information about ciguatera is collected by the Department of Environment and Coastal Resources, (Fisheries Division). The respondent did acknowledge that cases of CP do occur but did not know the 
number of CP cases identified each year. CAREC reports there were between 0 and 121 cases per year during the study period.

\section{$\underline{\text { U.S. Virgin Islands } \quad \text { Ciguatera presence: Yes }}$}

Although a former employee of the Division of Fish and Wildlife previously collected information on $\mathrm{CP}$, this information was not available to the division after this individual retired. The Health Department did not return the questionnaire. Information on $\mathrm{CP}$ was only reported by the hospital on St. Croix. It reported the number of cases treated from 2000 through 2006, which averaged 12 per year. It also determined that the average cost of treatment for each case was approximately $\$ 545$. A representative of the Division of Fish and Wildlife indicated that fishermen and citizens are both very aware of and very concerned about the risks of CP. CP cases have been reported in the literature, although not during the study period.

\section{$\underline{\text { Venezuela }}$}

\section{Ciguatera presence: Yes}

No questionnaires were completed for Venezuela. However, the National Institute of Fisheries and Aquaculture confirmed that ciguatera cases have occurred in Venezuela, but there were no statistics available on the number of cases identified. The respondent indicated that most cases occur in the Los Roques archipelago. However, the Director of Epidemiological Surveillance for Venezuela indicated that there were no identified CP cases during the study period. In the literature, there is one report of a large outbreak of CP on a cruise ship in Venezuela, although this occurred prior to the study period.

Caribbean Epidemiology Centre (CAREC). CAREC Regular Publications Listing. http://carec.org/publications/reg-pub.html\#annual. (Accessed July 7, 2009).

CAREC. 2008a. CAREC Annual Report 2007. http://www.carec.org/pdf/2007-AnnualReport/ANNUAL_REPORT 2007.pdf. (Accessed July 24, 2009.)

CAREC. 2008b. Morbidity Review of Communicable Diseases in CAREC Member Countries, 1980 - 2005: Ciguatera.

http://www.carec.net/pdf/mobidityreview/5.\%20Ciguatera.pdf. (Accessed July 24, 2009.)

Pan American Health Organization (PAHO). 2001. Regional Core Health Data System- Table Generator. Basic country health profiles for the Americas. http://www.paho.org/english/sha/profiles.htm. (Accessed July 15, 2020).

Tester, P.A., Feldman, R.L., Nau, A.W., Faust, M., Litaker, R.W., 2009. Ciguatera fish poisoning in the Caribbean. Smithsonian Marine Science Symposium 38, 301-311.

Tester, P.A., Feldman, R.L., Nau, A.W., Kibler, S.R., Litaker, W.R., 2010. Ciguatera fish poisoning and sea surface temperatures in the Caribbean Sea and the West Indies. Toxicon $56(5), 698-710$. 